Portland State University

PDXScholar

8-24-1973

Recent Developments in the Use of Precast Concrete Units for Buildings in the United States and Iran

Khosrow Ebadi Farshchi

Portland State University

Follow this and additional works at: https://pdxscholar.library.pdx.edu/open_access_etds

Part of the Architectural Engineering Commons, and the Structural Materials Commons Let us know how access to this document benefits you.

Recommended Citation

Farshchi, Khosrow Ebadi, "Recent Developments in the Use of Precast Concrete Units for Buildings in the United States and Iran" (1973). Dissertations and Theses. Paper 1655.

https://doi.org/10.15760/etd.1654

This Thesis is brought to you for free and open access. It has been accepted for inclusion in Dissertations and Theses by an authorized administrator of PDXScholar. Please contact us if we can make this document more accessible: pdxscholar@pdx.edu. 
AN ABSTRACI OF THE PHESTS OF Khosxow Ebadi Farshchi for the Master of Science in Applied Science presented August 24 , 1973

Title: Fecent Levelopments in the Use of Precast Concrete Unj.ts for Buildings in the United States and Iran

APPROVET BY MERBERE OW THE THESIS CONAITPES:

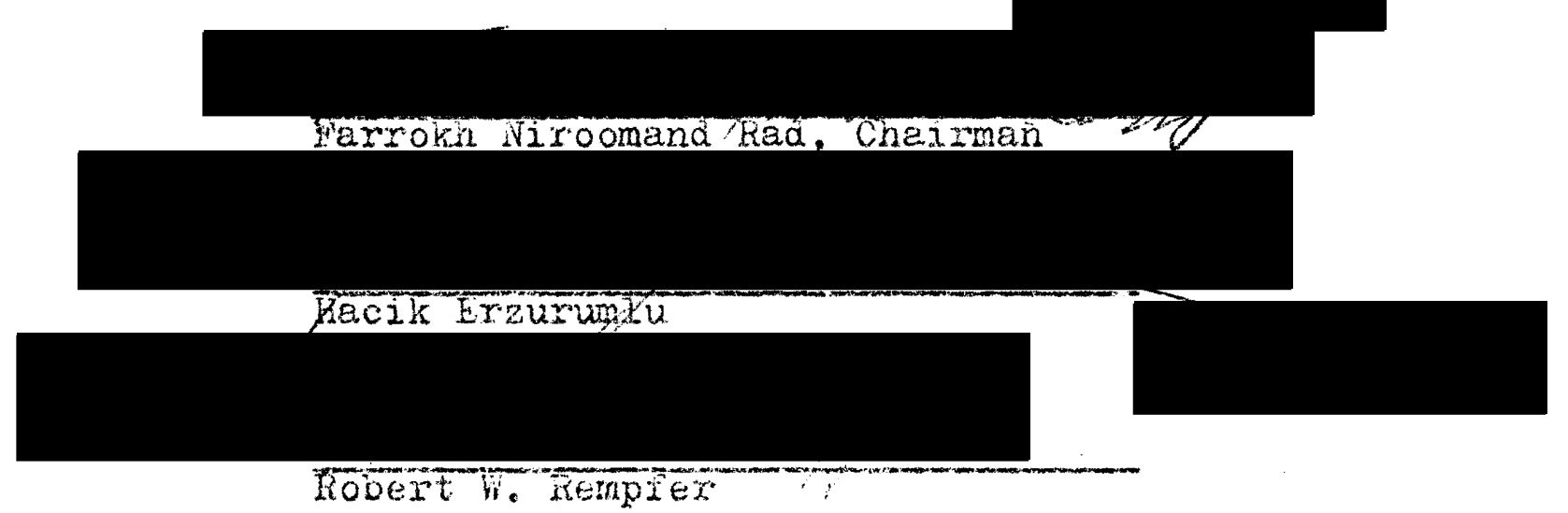

The object of this study was to irvestigate the recent developments in the use of precest prestiessed comcrete mero bers for buildinge in the United States ard Iran.

Ir the united states, the stuly was concerned with arevelopments in the ugage of memoexs such as alabs, wall panels. beams and columns. Wne letest technical ancengineering reports, elong with persoial intaxviews, were used, and a number of case studies were conducted on recently buiit structures,

The author also studied the newest devalopinents in the s. precast concrete incustry in fian. A questionaire was form 
mulated in both Persian (native language of Iran) and English, and was sent to twelve of the largest precast concrete manufacturers in Iran. This study was extended to include tha use of precast concrete members in alleviating Iran's housing shortage, which is one of the greatest problems facing the country today.

From these studies the following observations have been made with respect to the United States:

1) There is a vast variety of precast concrete units designed and manufectured in the country.

2) The majority of precast concrete units in buildings are assembled by using simpie connections.

3) There has been great improvernent in the quality of sealant materials.

4) In the case studies conducted, it was evident that proper planning in design, production, transportation and erection of members were the major reasons in lowering the cost of precast concrete structures as compared to cast-inplace structures.

5) The rapid increase in the use of precast concrete members is due to repetition of similar members, increase in strength and serviceability by prestressing, rapid construction, better quality control, improvement in handing and fire resistance qualities.

In the case of Iran, tine following observations have been made: 
1) The use of precast concrete members has increased rapidy in the last decade.

2) Precast concrete construction, with proper shear design, appears suitable in areas where there is stronger and more frequerit earthquake occurrence.

3) Precast concrete members are considered to be suitable for low-cost housing projects because of the availability of cement and steel reinforcement, an inadequate supply of wood and also beceuse of the advantages of precast concrete mentioned above. 


\title{
RECENT DPVETOPNENTS IN TRE USE OF PRECAST CONCEETE UNITS FOR BUILDINGS IN THE UNITED STATES AND IRAN
}

\author{
by \\ KHOSROW EBADI FAFSILIII
}
A thesis submitted in partial rulfillment of the requirements for the degree of

\author{
MASTER OF SCIENCE \\ in \\ APPLIED SCIENCE
}

Portland State University

1973 


\section{TO THE OFFICE OF GRADUATE STUDIES AND RESEARCH:}

The members of the Committee approve the Thesis of Khosrow Ebadi Farshchi presented August 24, 1973.
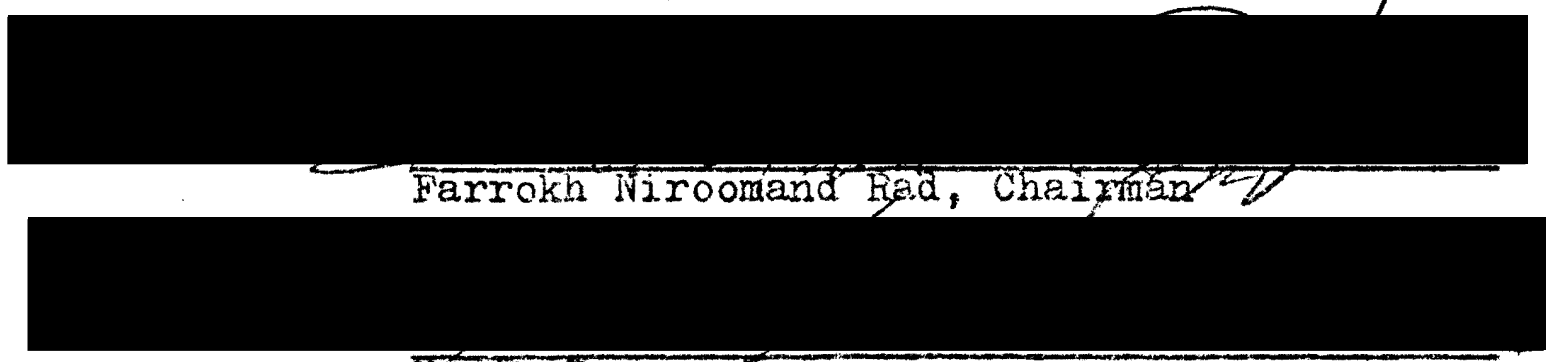

Pacik Erzurupinu

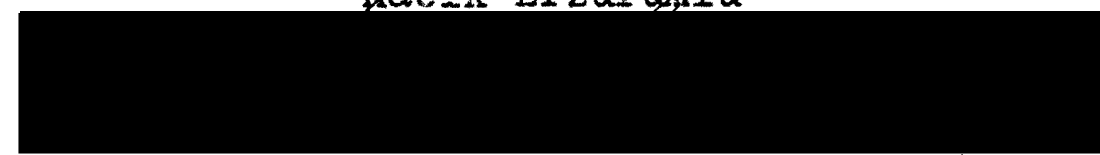

Robert W. Rempfer

APPROVED:

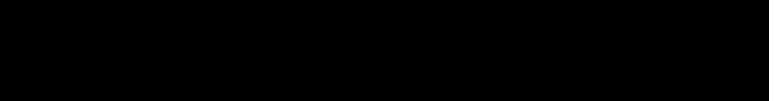

Nan-Ieh Hsu, Head, Department of Applied Science

David T. Clark, Dean, Graduate Studies \& Research 
TO MY

\section{PARENTS}

Ali Akbar and Rabieh Ebadi Farshchi

and

MY BROMHER

Johengir Ebadi Farshohi 


\section{ACKNOWLEDGEMENTS}

Most properly, I wish to express my appreciation and gratitude to Dr. Farrokh Niroomand Rad, supervisor of this study, for his advice and expert guidarce in completing this thesis.

I also wish to express my thanks to Dr. Hacik Erzurumlu, who started me in my graduate studies. Portland, Oregon August, 1973 
TABLE OF CONTENTS

Page

ACKNOWLEDGEMENTS. . . . . . . . . . . iv iv

IIST OF TABLES. . . . . . . . . . . . . ix

IIST OF FIGURES ................ . . . $x$

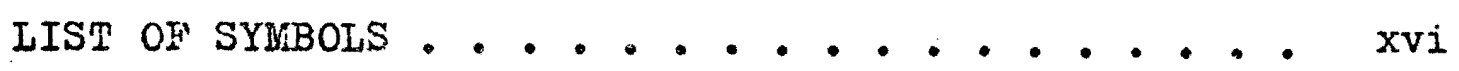

Chapter

I. INTRODUCTION . . . . . . . . . . . 1

1.1 General . . . . . . . . . . 1

1.2 Objects and scope of Study. ..... 5

II. ORDINARY AND PRESTRESSED CONCRETE. . . . 7

2.1 Introduction. . . . . . . . 7

2.2 Ordinary Reinforced Concrete..... 8

2.2.1 Naterials and Specifications . . 8

A. Concrete....... 8

B. Compressive, Tensile and

Shear Strength..... 8

C. Creep and Shrinkage of

Concrete...... 10

D. Reinforcing Steel. .... 12

2.2.2 Reinforced Concrete Analysis . 14

A. General. ....... 14

3. Flexure lienbers. .... 15

c. Compression Nembers. . . 17 
2.2.3 Strength and Serviceability. . 18

A. Strength . . . . . 18

B. Serviceability . . . . 19

2.2.4 Details of Reinforcement . . . 20

A. General. . . . . . 20

B. Corbels and Brackets . . 20

C. Column Face Plate and

Precast Beam Bearing . . . 21

D. Anchorage. . . . . . 23

2.3 Prestressed Concrete. . . . . . . 26

2.3.1 Materials and Specifications . . 26

A. Concrete... . . . 26

B. Steel for Prestressing . . 28

2.3.2 Design Concepts. ....... 31

2.3.3 Strength and Serviceability
Considerations . . . . . 32

A. General. . . . . . 32

B. Strength . . . . . . 35

C. Serviceability . . . . . 35

2.3.4 Prestressing Systems. . . . 35

III. DEVELOFHENTS IN THE USE OF PRECAST CONCRETE UNITS FOR BUILDINGS IN THE UNITED STATES • • 37

3.1 Introduction. . . . . . . . . 37

3.2 Precast Concrete Units. . . . . . . 39

3.2 .1 Beams. . . . . . . . . 39

3.2 .2 Slabs. . . . . . . . . 42

3.2 .3 Columns. . . . . . . . 46 
3.2.4 Vall Panels. . . . . . . 49

3.3 Connections . . . . . . 68

3.3.1 General. . . . . . . . 68

3.3 .2 Design . . . . . . . . 69

A. Pransfer of Shear. . . . 69

B. Transfer of Homent . . . . 72

C. Transfer of Axial Tension
and Compression. . . . 76

3.3.3 Conrection Details . . . . . 77

A. Column to Foundation . . . 77

B. Column to Column ..... 80

C. Beam to Column ...... 83

D. Beam to Beam . . . . . . 83

E. Slab to Beam or to SIab. . 83

3.4 Sealant Materials and Joint Details. . 90

3.4.i Sealant Materials. . . . . . 90

3.4.2 Joint Details. . . . . . . 92

3.5 Fire Resistance . . . . . . . . 99

3.6 Trree Fecently Built Structures Using

Precast Concrete Units. . . . . . 106

3.6.1 Case Study \#1......... 106

3.6.2 Case Study \#2. . . . . . . . 116

3.6.3 Case Study \#3. . . . . . . 119

IV. USE OF PRECAST CONCRETE UNITS FOR BUILIINGS

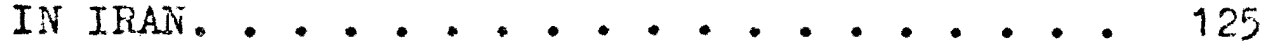

4.1 Geography . . . . . . . . . . 125

4.2 Climate . . . . . . . . . 128 
viii

Chapter Page

4.3 Eartinquake. . . . . . . . . 131 4.4 Steel Production. . . . . . . . 133

4.5 Cement Production . . . . . . . . 134 4.6 Housing Problem in Iran . . . . . . 136

4.7 Low-Cost Housing. . . . . . . . . 139

4.8 Six Major Precast Concrete Plants in Iran. . . . . . . . . . . 142

V. CONCLUSION . . . . . . . . . . . 157

5.1 United States . . . . . . . . . 157

5.2 Iran. . . . . . . . . . . 159

REFERENCES . . . . . . . . . . . . . 160 


\section{IIST OF TABLES}

Table

II-1. Tengile and Yield Strength for Prestressing Vires . . . . . . . . • 28

IV-1. Different Climatic Region of Iran . . . . 130

IV-2. Information Obtained from Six Precast Concrete Plants. . . . . . . . . . . 144

IV-3. Partial List of Buildings Built in Iran using Precast Prestressed Concrete Members. . . 147 
IIST OF FIGURES

Figure

Page

2.1. Range in Proportion of Materials Used in Concrete. . . . . . . . . . . 9

2.2. Concrete Stress-Strain Curves from Compression Cylinders . . . . . . . . . . 11

2.3. Creep and Elastic Deformation. . . . . 13

2.4. Compressive Stress Distribution at Failure - 16

2.5. Application of Shear-Friction in Corbel. . 22

2.6. Column Face Plate. . . . . . . . . 22

2.7. Precast Beam Bearing . . . . . . . 22

2.8. Reinforcement Development in Simply Supported Beams... . . . . . . . . 24

2.9. Anchorage Requirement; (a) Anchorage into Exterior Column, and (b) Anchorage into Adjecent Beam. . . . . . . . . . . 24

2.10. A Bracket. . . . . . . . . . . 25

2.11. Typical Stress-Strain Curve for 5,000 Psi Concrete.................. 27

2.12. Typical Stress-Strain Curve for Prestressing Steels............. 30

2.13. Intermal Resisting Moment in Prestressed and Reinforced Concrete.............

2.14. Stress Distribution Across an Eccentrically Prestressed Concrete Section . . . . . 33

3.1. Rectangular Beam Cross-Section . . . . . 40

3.2. Single-Tee Beam Cross-Section. . . . . . 40

3.3. Double-Tee Beam Cross Section. ...... 40

3.4. Inverted-Tee Beam Cross Section. . . . . 41

3.5. I-Shape Beam Cross Section . . . . . . 41

3.6. Girder Beams Cross-Section . . . . . . 41 
Figure

Page

3.7. Dymaspan Hollow-Core Slab . . . . . . 44

3.8. Span-Deck Hollow-Core Slab. . . . . . 44

3.9. Typical Ioad Span - Curves for 8" Deep No

Topping Hollow-Core Slab. . . ... . . 45

3.10. Rectangular Cross-Section ......... 47

3.11. Rectangular Cross-Section Spirally Tied • . 47

3.12. Typical Round Columns with Spiral Wire. • 47

3.13. Typical Square Colunns with 4-Bars and Tie. 47

3.14. Square Columns with 8-Bars and Ties. . . 48

3.15. Square Columns with 12-Bars and Ties. . . 48

3.16. Typical Rectangular Column Steel Arranged

for Bending and Axial Load. . . . . . 48

3.17. Typical Axrangement of Comer Columns . . 48

3.18. Typical Flat Panel Cross-Sections . . . 52

3.19. Common Type of Precast Double-Tee Wall Panels................. . . 52

3.20. Typical Ribbed Panel Section. . . . . 53

3.21. Typical Hollow-Cored Parel Section. . . 53

3.22. Typical Two-Story Window Wall Parels. . . 55

3.23. A Typical Sandwich Wall Panel . . . . . 57

3.24. Allowable Compressive Stress for Precast Concrete Panels, based on $h / t_{e}$ Ratio, Recommended by ACI Committee 533......

3.25. Ultimate Design Relationship for Precast Reinforced Wall Parels. . . . . . . . .

3.26. Ultimate Design Relationships for Precast, Prestressed Viall Panels... ..... 64

3.27. Reinforced Dowels . . . . . . . . 71

3.28. Concrete Bracket. . . . . . . . . 71 
Figure

Page

3.29. Confinement Angle Used in Bracket. . . . 73

3.30. Steel Bracket in Beam-Column Connection. . 73

3.31. Shear Transfer Devices for Beams and Columns . . . . . . . . . . 74

3.32. Shear Loading on Stud Near Free Ends . . . 74

3.33. Bolt or Stud for Shear Transfer and Anchorage. . . . . . . . . 75

3.34. Column to Footing Connection ...... 78

3.35. Column to Base Connection. ....... 79

3.36. Typical Assembly of Post-Tensioning Columns ............... 81

3.37. Wall-to-Well Connection. ....... 82

3.38. Knife Connection for Beam to Column Types. - 84

3.39. Exterior Wall-to-Wall Connection ..... 85

3.40. Connection Details of Beam to Wall .... 86

3.41. Connection of Beam to Beam ....... 86

3.42. Connection Details of Beam to Beam .... 87

3.43. Connection Details of Beam to Beam .... 87

3.44. Connection Details of Slab to Slab . . . 87

3.45. Typical Bearing on Interior Concrete Beam Connection of Slab to Beam and Slab. .... 88

3.46. Typical Bearing on Exterior Concrete Beams Slab to Beam Connection. ....... 88

3.47. Typical Bearing on Interior Concrete Beam, Connection of Slab to Slab and Beam. ...

3.48. Typical Bearing on Exterior Concrete Beam with Cantilever, Connection of Slab to Beam ...............

3.49. Recessed Vertical and Horizontal Butt Joint. 
Figure

Page

3.50. Comer Joint Detail and Panels with Narrow

Ribs. . . . . . . . . . . . 94

3.51. Two-Stage Joint Vertical and Horizontal

Gaskets . . . . . . . . . . 96

3.52. Two-Stage Joint Vertical and Horizontal

Sealants. . . . . . . . . . . 97

3.53. Floor and Roof Slab Joint Details . . . . 98

3.54. Effect of Various Types of Aggregate on the Fire Endurance of 4 3/4-in. Slabs . . . 101

3.55. Relationship of Slab Thickness and Type of Aggregate to Fire Endurance. . . . . 101

3.56. Effect of Temperature on Modulus of Elasticity anó Compressive Strength . . . . 102

3.57. Effect of Temperature on the Yield Strength of Reinforcing Steel. . . . . . ... 102

3.58. Thermal Gradient in a 6-in. Slab After $2 \mathrm{Hr}$. Fire Exposure . . . . *. . . . 105

3.59. General View of John Adams High School. - 108

3.60. Window Vall. Panels (John Adams High School) 108

3.61. Spandral Beams (John Adams High School) • 110

3.62. A Close-Up of a Spanaral Beam (John Adams High School). . . . . . . . . . . 111

3.63. Walkway Cover Panel Used for First Floor (John Adams High School). . . . . . 112

3.64. Welkway Cover Panel Used for Second Floor (John Adams High School)..........

3.65. Tee Beam of Gymnasium (John Adams High School) . . •. •. •. •. •. . 115

3.66. Tee Beam of Auditorium (John Adams High School) . . . . . . . . . . . 115

3.67. General View of Marshall Union Manor Building. • . . . . . . . . . . . 117 
3.68. Another View of Marshall Union Manor Building. . . . . . . . . . . . 118

3.69. Typical Cross-Section of Exterior Bearing irall. . . . . . . . . . . 120

3.70. Typical Cross-Section of Core Slabs . . 120

3.71. Typical Slab to Wall Panel Connection Detail 121

3.72. Typical Slab to Slab Connection Detail. . 121

3.73. Cast-in-Place Covering of Opening Between Two Slabs................ 122

3.74. General View of Bridgeport Garage . . . . 124

4.1. Map of Persia (Iran) and Its Neighbors. - 127

4.2. Major Earthquakes in Iran . . . . . 132

4.3. Upper Levels of Iran National Bank Building, Shahreza Ave., Tehran, Iran . . . . . 148

4.4. Main Level of Iran National Bank Building, Shahreza Ave., Tehran, Iran . . . . 148

4.5. Saman Building, Ilzabet Ave., Tehran, Iran. 149

4.6. Adjoining Towers of Saman Building, Ilzabet Ave., Tehran, Iran. . . . . . . 150

4.7. Front View of Communication Building, Sepah Square, Tehran, Iran... . ... . 151

4.8. Rear View of Communication Building, Sepah Square, Tehran, Iran. . . . . . . 151

4.9. Close-up of Communication Building, Sepah Square, Tehran, Iran. . . . . . . . 152

4.10. Side View of Korosh Department Store, Pahlavi Ave., Tehran, Iran . . . . . . 153

4.11. Front View of Korosh Department Store, Pahlavi Ave., Tehran, Iran . . . . . . . 154

4.12. Front View of Agricultural Building, Ilzabet Ave., Tehran, Iran. . . . . . . 154 
Figure

$\mathrm{xV}$

4.13. Side View of Agricultural Building, Ilza-

bet Ave., Tehran, Iran. ....... 155

4.14. Arymehr Stadium, Tehran, Iran . . . . 156 


\section{IIST OF SYMBOLS}

A = Effective tension area of concrete surrounding the main tension reinforcing bars, and having the same centroid as that reinforcement, divided by the number of bars

$\mathrm{A}_{\mathrm{b}}=$ Area of an individual bar

$A_{\text {comp }}=$ Cross-Section of concrete compression area

$A_{p s}=$ Area of prestressed reinforcement in tension zone

$A_{s} \quad=$ Area of tension reinforcement, and, also, shank area of stud

$A_{v}=$ Shear reinforcement

$A_{v f}=$ Area of shear reinforcement

$A_{S}^{\prime} \quad=$ Area of compression reinforcement

a $=$ Depth of equivalent rectangular stress block

$a_{1}=$ Deflection, or camber

b = Width of cross-section

$\mathrm{b}_{\mathrm{w}} \quad=$ Web width, or diameter of circular section

c = Distance from the neutral axis to extreme fiber

D = Dead loads, or their related intermal moments and forces

d = Distance from extreme compression fiber to centroid of tension reinforcement

$a_{b}=$ Nominal diameter of bar, wire or prestressing strand

$d_{c}=$ Thickness of concrete cover measured from the extreme tension fiber to the center of the bar 10cated closest thereto

$\mathrm{E}=$ Load effects of earthquake, or their related intermal moment

$E_{c} \quad=$ Modulus of elasticity of concrete

$E_{c i}=$ Modulus of elasticity of concrete after losses due to prestressing 
$\mathrm{E}_{\mathbf{s}} \quad=$ Modulus of elasticity of steel

e $\quad=$ Eccentricity at point of consideration

$e^{\prime}=$ Eccentricity at midspan (if there are curved tendons)

$\mathrm{F}_{\mathrm{a}} \quad=$ Allowable compressive stress in panels $f_{p s}=\begin{aligned} & \text { Calculated stress in prestressing steel at des- } \\ & \text { ign load }\end{aligned}$

$f_{p u}=$ Ultimate strength of prestressing steel

$f_{p y}=$ Specified yield strength of prestressing steel

$f_{r}=$ Modulus of rupture of concrete

$f_{s}=$ Calculated stress in reinforcement at service loads

$f_{\text {se }}=$ Effective stress in prestressing steel after losses $f_{y}=\underset{\substack{\text { Specified yield strength of non-prestressed rein- } \\ \text { forcement }}}{-}$

$f_{c}^{\prime} \quad=$ standard cylinder strength of corcrete

$f_{s}^{\prime} \quad=$ Calculated stress in compressive reinforcement

$\mathrm{h}=$ Height of panels

I $=$ Moment of inertia

$I_{g}=$ Gross monent of inertia of section

I $=$ Live loads, or their related internal moments and forces

$I_{a}=$ Adaitional embedment length at support at point of inflection

$I_{\mathrm{d}}=$ Development length

$M_{t}=$ Theoretical moment strength of a section $=$ $A_{s} f_{y}(d-a / 2)$

$\mathrm{Mu}_{\mathrm{u}}=$ Ultimate momerit capacity of flexure members

$\mathrm{m}=$ Meter

$\mathrm{mm}=$ Milimeter 


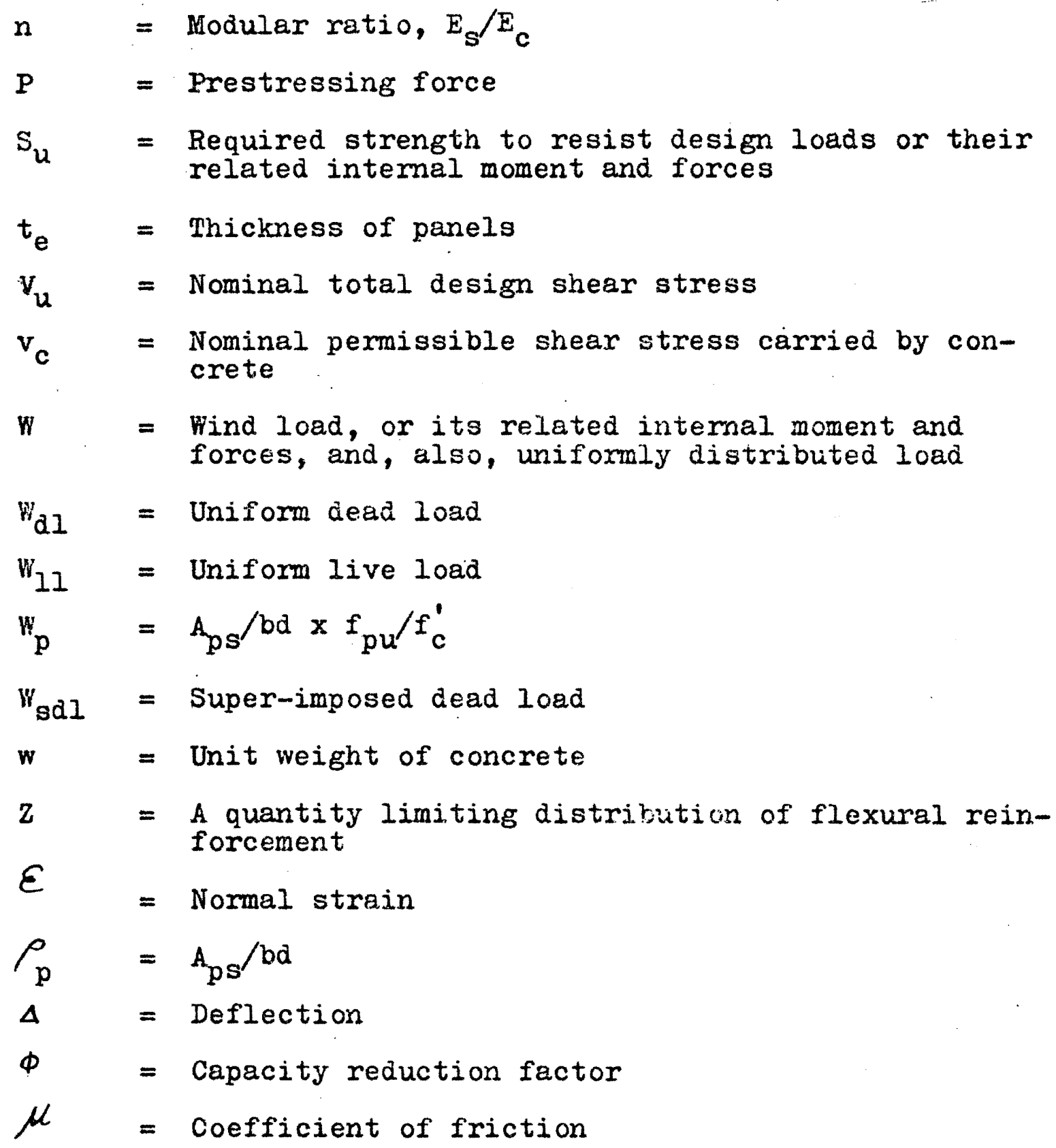




\section{CHAPTER I}

\section{INTRODUCTION}

\subsection{GENERAI}

The use of precast concrete members is not a recent development in the United States. Limited use of precast members (wall panels) started prior to 1912, when units were cast at the job site, and liftea into place. ${ }^{6}$ Similar methods were used for several housing developments and buildings of various occupancies built between 1912 and 1940.6

The more rapid increase of the use of precast concrete load bearing units for building started after 1955. This rapid increase was mainly due to the realization of the advantages of precast concrete members by architects and structural engineers. The growth in use and variety of precast concrete members for building has been so spectacular in recent years that it has overshadowed much of the earlier work.

This tremendous increase in recent years is due to the advantages of constructing parts of a structure, or sometimes the entire structure with precast members. This is mostly because of the repetition of similar members, which makes it more economical to precast. Other reasons are rapid con- 
struction aue to assembling the precast members, and decreasing the labor cost compared to cast-in-place construction.

In addition to the advantages given above, precast concrete members have the following advantages:

1) less risk of the reinforcement being displaced;

2) better finish:

3) construction not interrupted by adverse weather conditions.

The main disadvantages of precast concrete members are:

1) handing and transportation costs;

2) damage from repeated handling;

3) jointing.

It should be clear that precast concrete members are built because they are more economical to construct; certainly not because they are easier to design. ${ }^{7}$ They are also built when there is an architectural xequirement for precise and complex formed surfaces. In general, precast buildings can be made more economically only when advantage is taken of the smooth and precise surfaces obtainable in factory production. 7 These may be exposed and need not be hidden behind plaster, thus leading the architect to full expression of the structure.

In the production of precast concrete members, maximum economy can be achieved in the selection by utilizing section and details that permit efficient production such as: 
1) use of available standard sections;

2) for slabs, use of repetitive types of member reinforcement details, strand patterms in the case of prestressing, embedded plate details, plate anchorages, inserts and concrete strength;

3) minimizing the number of special slabs with openings or blockouts.

In production of precast concrete members, maximum size is governed by:

1) weight in relation to method of lifting;

2) length of transporter;

3) restriction of site;

4) access to site.

Other important points to consider in the construction of precast concrete members are connection and joints. In designing adequate connections and joints, the following should be considered:

1) capability of transferring stresses;

2) geometric accuracy;

3) water proofing where necessary.

Special attention should be given to the connection design of precast concrete members in order to obtain floor and roof diaphragm action. Joints must take shear in both horizontal (diaphragm action) and vertical (distribution of concentrated vertical load directions. Connection should maintain its strength while preventing rotation of the member about its own axis. 
Generally, simple span construction is more economical for precast concrete members because of connection, production and construction simplicity. Unless analysis indicates otherwise, the framing system should utilize only the number of rigid frames required to resist the lateral loads, and the rest of the building then can consist of simple spans. 


\subsection{OBJECTS AND SCOPE OF STUDY}

The object of this study was to irvestigate the recent developments in the use of precast concrete members for buildings in the United States and Iran.

In the United States, the study was concemed with developments in the usage of members such as slabs, wall panels, beams and columns. The latest technical and engineering reports, along with personal interviews were used. In Chapter 2, cesign and analysis of both ordinary reinforced concrete and prestressed concrete are discussed. Chapter 3 is devoted to recent developments in this field. A number of case studies were conducted on recently built structures. These structures were predominantly built with precast concrete members. These studies show the manner in which members are assembled to create unique buildings.

The author also studied the newest developments in the precast concrete industry in Iran. A questionnaire was formulated in both Persian (native language of Iran) and English, which was sent to six of the largest precast concrete manufacturers in Iran. This study is discussed in Chapter 4. The study of precast concrete menbers in Iran was extended to include their use in alleviating Iran's housing shortage, which is one of the greatest problems facing the country today. This study includes the availability of concrete and 
steel reinforcement in the country. Also, climate variation and earthquake occurrence in various population areas are discussed. Chapter 5 is devoted to the conclusions of these two studies. 


\section{CHAPTER II}

\section{ORDINARY AND PRESTRESSED CONCRETE}

\subsection{INTRODUCTION}

Since all precast concrete units in buildings are either ordinary or prestressed, or both, in this chapter the general principles of design and analysis of both ordinary and prestressed concrete will be presented.

This chapter includes information on materials and code specifications for reinforced concrete. Design and analysis of reinforced concrete for both flexure and compression members are discussed. The strength and serviceability of the members are considered, referring to the ACI 318-71 Code $^{2}$ requirements.

Further, this chapter includes information relating to design and analysis of prestressed concrete, and a discussion of prestressing steel and anchorage systems. 


\subsection{ORDINARY REINFORCED CONCRETE}

\subsubsection{Materials and Specifications}

A. Concrete. Concrete consists of aggregate and paste, which is made of Portland Cement and water. Cement and water fill the voids in the aggregate, and after it hardens, it creates a strong bond and becomes a solid structural material, which is the most commonly used material in the world.

Range in proportioning of materials in concrete is shown in Fig. 2.1.16

The American Society for Testing and Materials (ASTM) specifies five types of Portland Cement, which are as follows: Type I, which is the most common cement used in general ordinary construction; Type II, which is used in construction where moderate sulfate problems exist; Type III, which provides high early strength within a short period of time such as a week or less; Type IV, which is used where the amount of heat generated should be minimized; and Type $v$, which is used when severe sulfate problems exist. 16

\section{B. Compressive, Tensile and Shear Strength. Com-} pressive strength of concrete can be obtained up to 10,000 Psi or more, but commercial production for general use is usually between 2,500 to 6,000 Psi. ${ }^{10}$ Specified compressive strength of concrete $f_{c}^{\prime}$ is based on at least 30 consecutive 
cement water Air Fine A99. Coarse A99.

1

\begin{tabular}{|c|c|c|c|c|c|}
\hline YYו1, & $\bar{\square}$ & & $\because \because \because \because \cdots:$ & 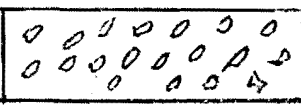 & $\begin{array}{l}\text { Air Entrain } \\
\text { Concrete }\end{array}$ \\
\hline $15 \%$ & 18 & $8 \%$ & 28 & $319 \%$ & \\
\hline
\end{tabular}

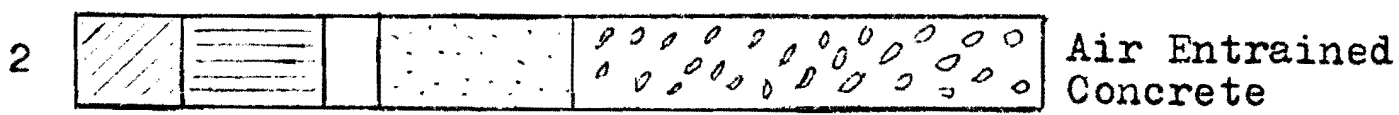
$7 \% \quad 21 \% \quad 3 \% \quad 24 \% \quad 51 \%$

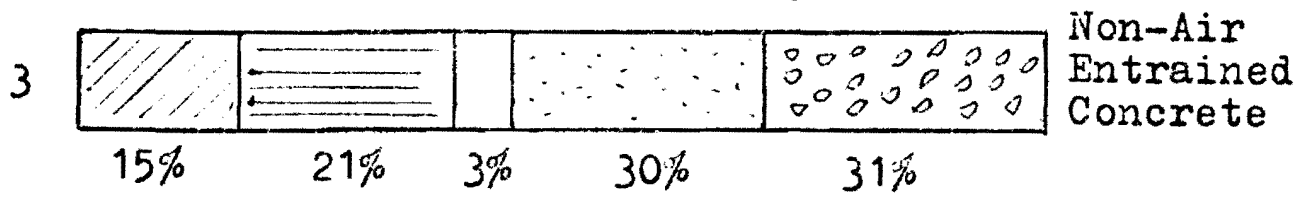

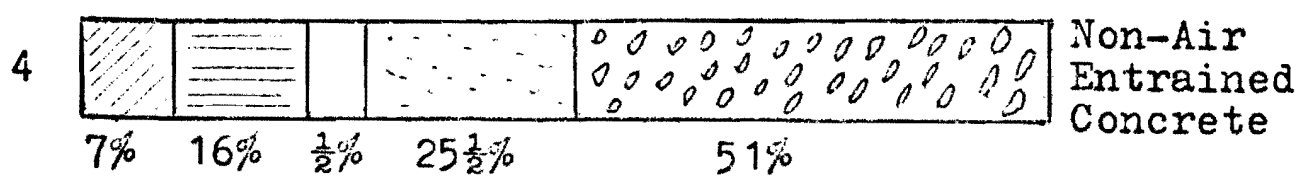

Figure 2.1. Range in Proportion of Materials Used in Concrete. Bars 1 and 3 Represent Rich Mixes with Small Aggregates. Bars 2 and 4 Represent Plixes with Large Aggregates. (From Ref. 16) 
strength tests as specified by the ACI 318-71 Code. ${ }^{2}$ It also gives values of specified compressive strength of concrete as related to water-cement ratio, which is when the strength date or field experience is not available. Value of $f_{c}^{\prime}$ ranges from 2,500 Psi to 5,000 Psi corresponding to the maximum permissible water-cement ratio of 0.65 to 0.31 (absolute ratio by weight) or 7.3 to 3.5 (U.S. gal. per 94 Ib. bag of cement).

The tensile strength of concrete is more difficult to measure, and from specimen to specimen it varies more than the compressive strength. The tensile strength is about $10 \%$ to $15 \%$ of the compressive strength, cccasionally $20 \%$. 10 Typical stress-strain curves for concrete cylinders on initial loading are shows in Fig. 2.2. ${ }^{10}$ It can be observed from the curves that strain occuring near maximum stress is nearly the same for all strength of concrete, and this value is around $0.002 \mathrm{in./in}$.

One other important property of concrete is the modulus of elasticity, which is the slope of the stress-strain curve. The modulus of elasticity $E_{c}$, for the concrete as given in ACI 318-71 Code ${ }^{2}$ is as follows: for weight of concrete between $90 \mathrm{Ib}$, and $155 \mathrm{lb}$. per cu. ft., $E_{c}=w^{1} .533 \sqrt{f_{c}^{\prime}}$, and for normal weight concrete (145 p pff), $E_{c}=57,000 \sqrt{f_{c}^{\prime}}$, where $w$ is the unit weight of concrete in 16 Ib. per cu. ft.

C. Creep and Shrinkage of Concrete. Increase of deformation with time is called creep. Variation of defor- 


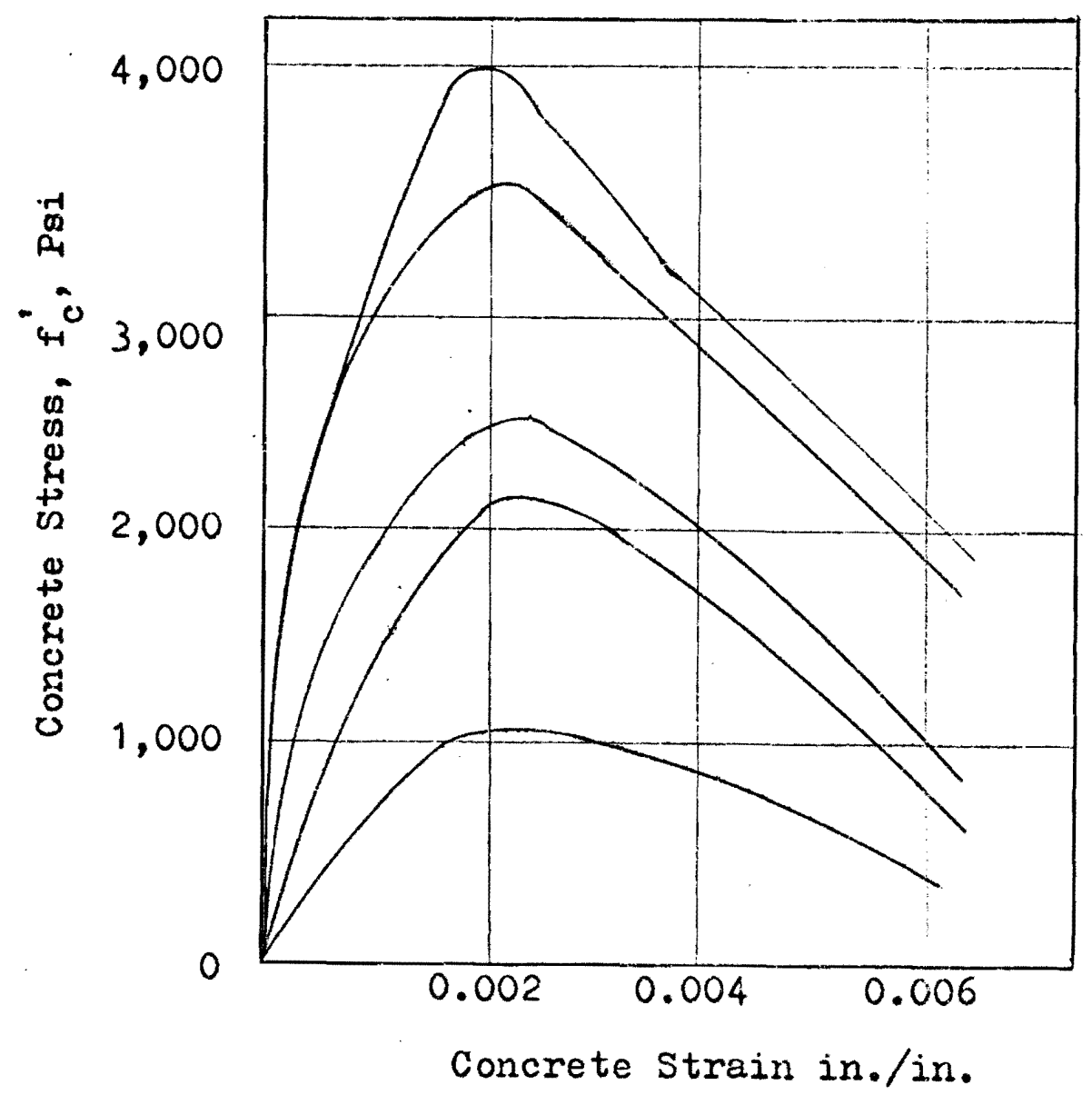

Figure 2.2. Concrete Stress-Strain Curves From Compression cylinders. (From Ref. 10) 
mation with respect to time is shown in Fig. 2.3. 10 It can be seen from the curve that the initial strain in concrete on first loading at low unit stress is nearly elastic, but strain increases with respect to time under the constant applied load. Factors which increase creep are; loading at an early age, exposing the concrete to drying conditions, and using concrete with a high water-cement ratio. ${ }^{10}$

Shrinkage of concrete is aue to loss of moisture by evaporation. Shrinkage of concrete is mostly differential shrinkage, since moisture losses are not uniform throughout the concrete. A method of expressing shrinkage is by using the shrinkage coefficient, which is the shortening per unit length. This coefficient has values between 0.0002 to $0.0006^{10}$

D. Reinforcing Steel. Reinforcing bars are made of steel in many grades. In order to create the bond between bars and concrete, projections are used which are rolled on the surface of the bars. All standara bacs are round and designated by size as \#2 to \#11. The designated number corresponds roughly to the bar diameter with an eighth of an inch (\#2 bar is plain bar). Later additions to the bar list are \#14S and \#18S. The yield strength of steel varies from 40 to $75 \mathrm{Ksi}$, which corresponds to ultimate strength of 70 to $100 \mathrm{Ksi}$ for different types of steel. ${ }^{10}$ The modulus of elasticity of steel reinforcement can be assumed as 29,000,000 Psi.

Another type of reinforcement in reinforced concrete is 


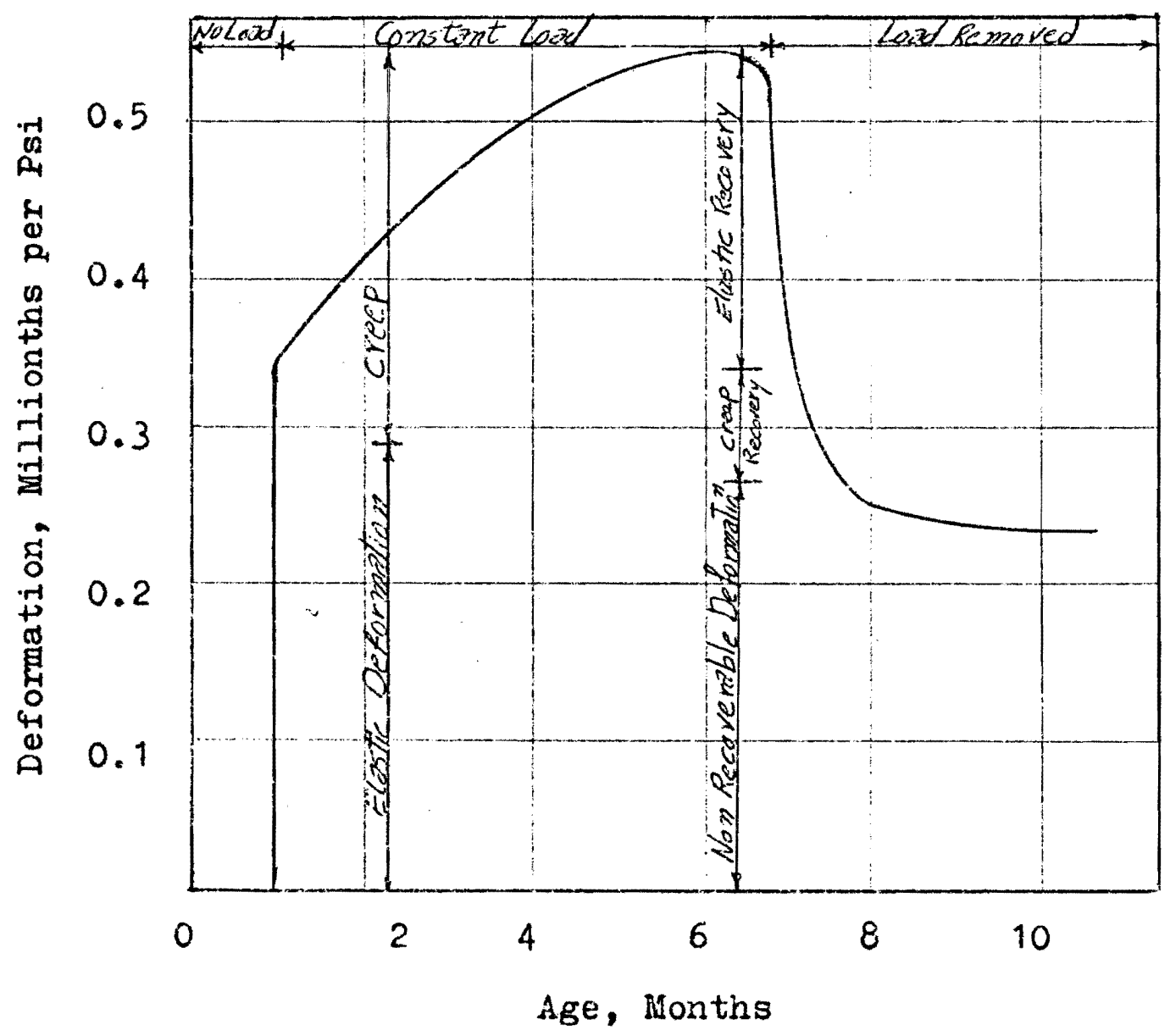

Figure 2.3. Creep and Elastic Deformation. (From Ref. TO) 
welded wire fabric, which is mostly used in slabs and pavements. This fabrio is made of cold-drawn wires running in two directions, and welded together at intersections.

\subsubsection{Reinforced Concrete Analysis}

A. General. In order to present the general concepts in the analysis of reinforced concrete members, it is necessary to divide the members into two categories; the first, flexure members, and the second, compression members. The flexure members in buildings are beams and slabs, in which the bending moment is the controlling factor in design or analysis of the member. Compression members are columns and bearing walls, in which the axial forces are the controlling factors in design or analysis of the member. It should be borne in mind that in the design of all practical columns, both axial load and moment exist, making the design more complicated.

Working stress design (VSD) and ultimate strength design (USD) are the two general methods used in design and analysis of reinforced concrete members. The working stress design is based on the theory that Hook's law holds both for concrete and steel, that is, both materials are elastic and have unit stresses directly proportional to unit strains. The transformed area concept is heipful in analysis using WSD. This concept constitutes the replacement of the area of steel by $n A_{S}$, where $n=E_{S} / E_{c}$.

The ultimate strength design, however, results in a 
more uniform factor of safety, greater economy of materials and a more consistent and less empirical design procedure. Provisions for design using USD are described in detail in the ACI 318-71 Code ${ }^{2}$, which generally employs more recent information on the behavior of reinforced concrete members.

B. Flexure Members. In the analysis of reinforced concrete flexure members, the concept of the resisting couple is used. Equilibrium holds that external bending moment on any beam must be resisted by internal tension and compression stresses. The tension stresses are generally carried by steel reinforcement and compression stresses by concrete, Resisting couples are used in both methods of working stress design and ultimate strength design. The ACI 318-71 code ${ }^{2}$ allows the following close assumptions in using WSD; a plane section before bending remains plane after bending; the stress-strain relationship for concrete is a straight line under service loads within the allowable working stresses; the steel takes all of the tensions. For members so designed, all allowable stresses for concrete and steel. are specified as $0.45 \mathrm{f}_{\mathrm{c}}^{\prime}$ and $20 \mathrm{Ksi}$ (for grades 40 and 50 ).

In designing the flexure members by ultimate strength design, the design is based on the stress distribution when the beam actually fails under overload. For simplification in analysis or design, the compressive stress distribution, which is usually a parabolic distribution, is replaced by an equivalent rectangular stress of intensity $0.85 \mathrm{f}_{\mathrm{c}}^{\prime}$ and 
depth of $a=\zeta_{1} c$, as shown in Fig. 2.4. ${ }^{10}$ The value of $c$ is the distance from the neutral axis to extreme fiber, and the value of $\beta$ is in the order of $0.85 .^{2}$

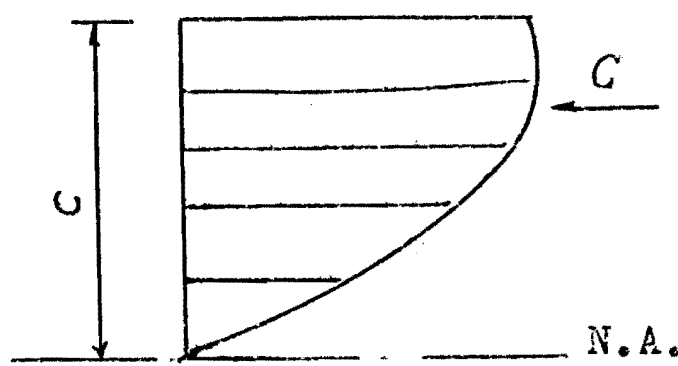

(a) Actual

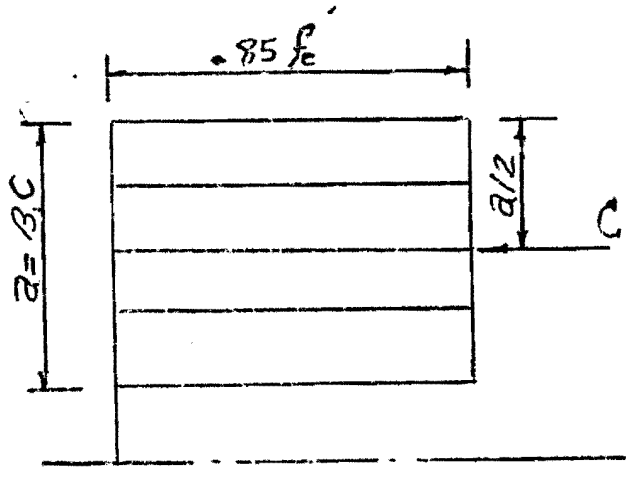

(b) Equivalent

Figure 2.4. Compress Stress Distribution at Failure, (a) parabolic (actual). (b) Equivalent Rectangular Stress Block.

In the flexure nembers, aside from moment, shear stress must also be investigated. The nominal shear stress is defined as $v_{u}=v_{u} / \phi v_{w} d$, where $\phi=0.85$. In the ACI 318$71 \mathrm{Code}^{2}$, permissible shear stress carried by the concrete, $v_{c}$, shall not exceed $2 \sqrt{f_{c}^{\prime}}$. when the concrete is unable to carry the applied shear, shear reinforcement is requirea. When shear reinforcement, which is commonly perpendicular to the longitudinal axis: is used, the required area of shear reinforcement can be obtained by $A_{u}=\left(v_{u}-v_{c}\right) b_{w} S / f_{y}$. The ACI 318-71 Code ${ }^{2}$ requires that torsion effects be included whenever torsional stresses exceed the $1.5 \sqrt{f_{c}^{\prime}}$. Detailed formulas for computing the torsional stresses and design are expressed in the ACI 318-71 Cooje. ${ }^{2}$ 
c. Compression Members. Compression members in buildings are columns and walls, in which the axial forces are often the controlling, factors in design. Years ago, reinforced concrete columns and walls were generally designed as axially loaded, with no provisions for eccentricity of loading or length effects. To make the practice safe, extremely high factors of safety were used. 10

When USD was introduced into the code in 1956, it included a mandatory design for at least a minimum eccentricity of $0.05 t$ on spiral columns. Due to eccentricity consideration, much lower safety factors were permitted in design. In the ACI 318-71 $\mathrm{Code}^{2}$, the requirements are: the minimum eccentricity of 1,0 in., or $0.5 \mathrm{~h}$ for spirally reinforced columns, and $0.010 \mathrm{~h}$ for tied compression members. Slenderness effects (lengtin effects) must also be included. ${ }^{2}$ In the case of a wall, if the resultant of the load forces falls within the middle third of its thickness, the wall may be designed by the empirical formula in Section 14.2, ACI 318-71 Code. ${ }^{2}$ Otherwise, the eccentricity must be considered. For precast concrete members, the minimum design eccentricity may be reduced to 0.6 in., provided the manufacturing and erection tolerances are limited to one-third of the minimum design eccentricity. ${ }^{2}$ This can be considered as an advantage of precast concrete members over cast-in-place members.

The general concepts in the design of compression members, as for flexure members, are based on the resisting internal forces. The external loads which are axial forces 
and moments are resisted by internal tension and compression stresses. The tension forces are carried by steel reinforcement, and compression forces are carried by both steel and concrete (similar to beams with compression steel).

\subsubsection{Strength and Serviceability}

A. Strength. Structural mernbers shculd be designed to have enough strength to resist the anticirated loads. Also, it is necessary to check the members for deflection and cracking to determine whether they are within tolerable limits at service loads. This is generally done after the safety of the member, or floor systera, is determined by strength design. 8

The margin of safety is provided in two ways. First, the applied loads are multiplied by load factors to provide for excess load effects from such possible sources as overloads and simplified assumption in structural analysis. ACI 318-71 Code $^{2}$ requires that the actual or specified dead, live, wind, earthquake and other loads be increased by an appropriate load factor. The design strength at each section must be equal to or greater than the effects oi these load combinations: ${ }^{2}$

$$
\begin{aligned}
& U=1.4 D+1.7 L \\
& U=0.75(1.4 D+1.7 L+1.7 W) \\
& U=0.9 D+1.3 W
\end{aligned}
$$

where $D, I$ and $W$ are specifjed dead, live and wind loads. If resistance to earthquake loads or forces $E$ must be included in the design, 1.1E shall be substituted for $W$ in the 
above load considerations.

Secondly, the theoretical capacity of the structural element is reduced by a capacity reduction factor. This factor provides for the possibility of small adverse variations in material strengths, workmanship and dimensions. While individually these variations may be within limits of good practice, they may combine to result in under-capacity. The ACI 318-71 Code ${ }^{2}$ prescribes the following -factors: 0.90 for flexural members; 0.85 for bond, diagonal tension and anchorage; 0.70 for tied columns; and 0.75 for spiral columns.

B. Serviceability. It is necessary to check both deflection and cracking at service load levels, once the safety of the member or floor system is determined by strength design. Deflections must be computed and compared to allowable limits for particular loading combinations when the thickness used is less than the ninimum value given in Table 9.5 in the ACI 418-71 Code. ${ }^{2}$

To control crack widths, flexural reinforcement must be well distributed in the zones of maximum concrete tension. The final crack widths after a period of time depend on the magnitude of (1) flexural cracking, (2) shrinkage, (3) creep, and (4) temperature movements. 8

ACI Code ${ }^{2}$ sets limitations on strength of reinforcement used in design. It suggests that design shall not have a yield strength $f_{y}$ in excess of 80,000 Psi, except for prestressing tendons. When the yield strength $f_{y}$ for tension 
reinforcement exceeds 40,000 Psi, the ACI Code ${ }^{2}$ suggests that the cross-sections of positive and negative moment be proportioned such that the quantity of $z$ given by $Z=f_{s}{ }^{3} d_{c} A$ does not exceed 175 Kips per in. for interior exposure, and $145 \mathrm{Kips}$ per in. for exterior exposure. Stress in reinforcement at service load may be taken as 60 percent of specified yield strength $f_{\mathrm{y}^{\circ}}{ }^{2}$

\subsubsection{Details of Reinforcement}

A. General. Cver the years, a standard practice for reinforced conerete details was gradually developed. Since the 1956 Code, ACI Committee 318 has collected reports of various research and practice with high yield strength steels. ${ }^{2}$ The results of all these stuaies are described extensively in the new Code by ACI Committee $318 .^{2}$ In this section, however, important points concerning details of reinforcement in precast concrete members are discussed. These details concern corbels, column face plates, precast beam bearings, and anchorage and hooks, which are mostly used in assembling the precast concrete members.

B. Corbels and Brackets. Because brackets and corbels are relatively small members, details of bond, anchorage and bearing are very important. ACI 318-71 Code, Article 11.14 ${ }^{3}$, provides the following rules, which are derived from experience and test results.

1) The tension reinforcement should be anchored as close to the outer force as cover requirements permit. Welding the main bars to spiral devices such as cross bars equal in size to the main bar 
is one method of accomplishing this end.

2) The depth of a corbel measured at the outer eage of the bearing area should not be less than one-half of the required totai depth of the corbel.

3) The outex edge of the bearing area should not be closer than 2 in. to the outer edge of the corbel.

4) When corbels are designed to resist horizontal forces, tre bearing plate should be welded to the tension reinforcement.

To transfer shear force $v_{u}$ from beam to the column, the shear stress should be checked at tine interface between the corbel and the column (shear plane). ${ }^{3}$ Tension reinforcement, $A_{s}$, should be provided to resist the moment produced by $v_{u}$ at the face of the support and to resist the tensile force, $N_{u}$, created due to the friction forces between beam and corbel, as shown in Fig. 2.5.3

The required area of reinforcement is $A_{u f}=V_{u} / \Phi f_{y} \mu$. The designed yield strength $f_{y}$ shall not exceed 60,000 Psi. Also, the coefficient of friction, $\mu$, varies from 1.4 to 0.7 for various times of casting the concrete.

C. Column Face Plate and Precast Beam Bearing. For column face plates, headed studs are used in order to function as shear-friction steel. The studs should be firmly anchored into the confined core of the column. Fig. 2.6 shows the elevation view of colurun race plate. ${ }^{3}$

For precast beam bearing, bars are welded to the angle cast in beam in order to prevent cracking as shown in Fig. $2.7 .^{3}$ 


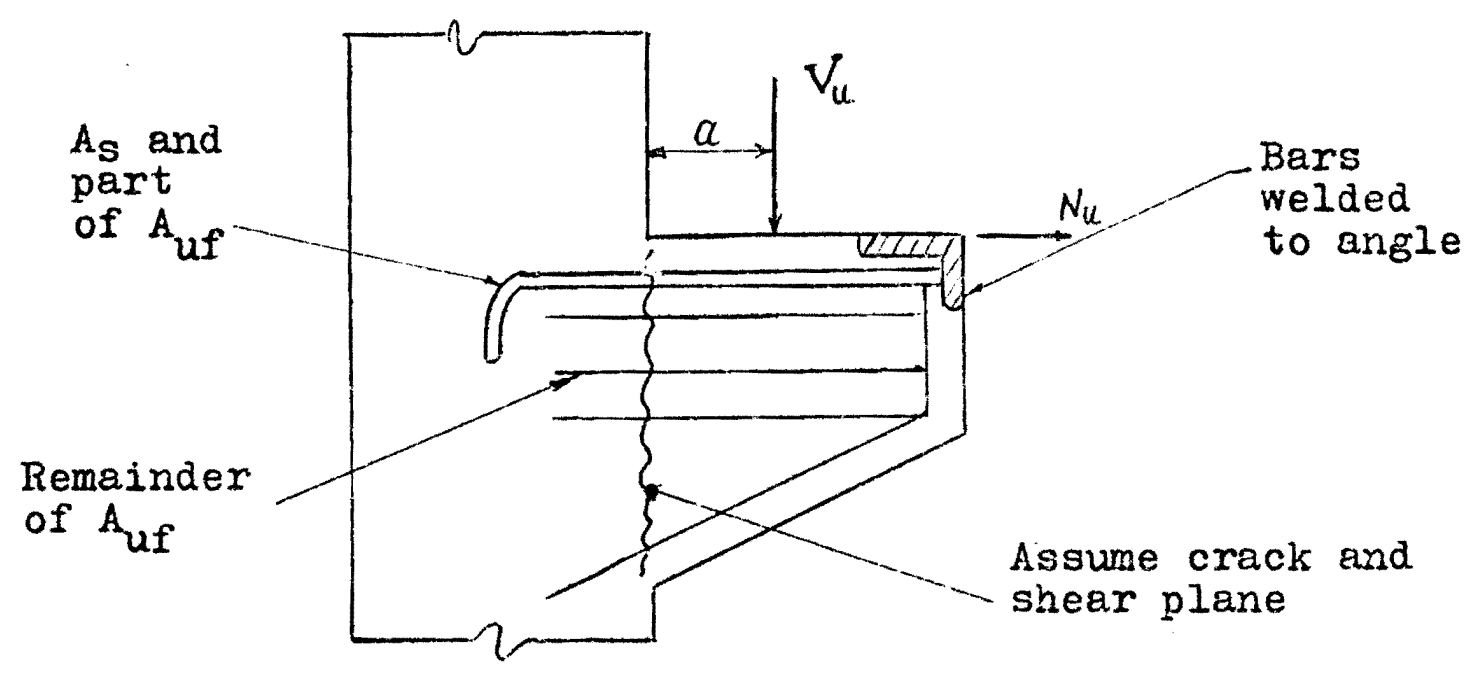

Figure 2.5. Application of Shear-Friction in Corbel. (From Rei. 3)

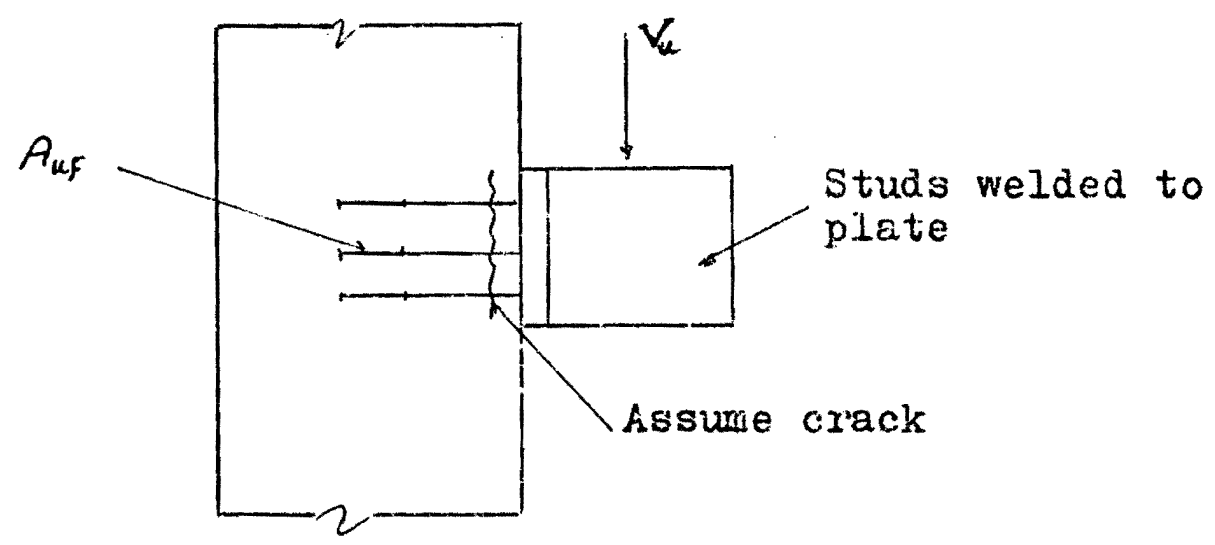

Figure 2.6. Column for Face Plate. (From Ref. 3)

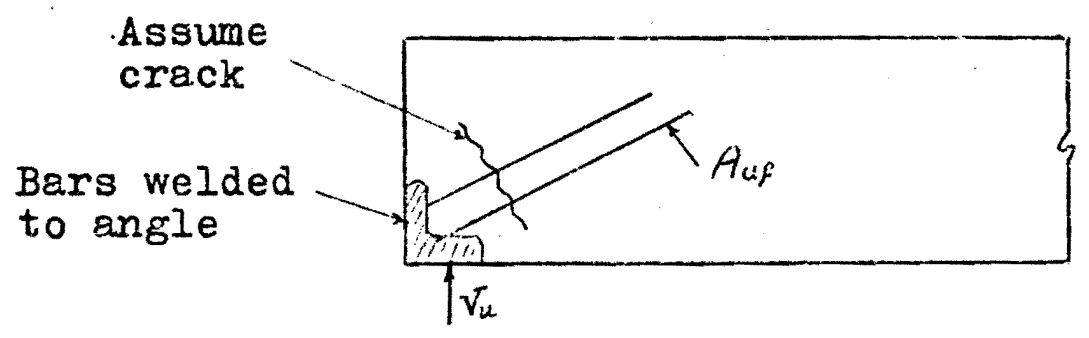

Figure 2.7. Precast Beam Bearing. (From Ref. 3) 
The Auf for both colurn face piate and precast beam bearing can be calculated from $A_{u f}=v_{u} / \phi f_{y} \mu{ }^{3}$

D. Anchorage. Development length or anchorage is necessary on both sides of a point where yielding must be developed. Anchorage consideration is very important in precast concrete members, since these members are often designed as simply supported, and should be anchored and connected to each other in order to transfer the stresses from member to member. The ACI code requirement for positive moment reinforcement must be small enough so that computed development length of the bar $I_{a}$ does not exceed $\mathrm{N}_{t} / \mathrm{V}_{u}+\mathrm{L}_{a}$ or $1.3 \mathrm{M}_{t} / \mathrm{v}_{u}$. The 1.3 factor is usuable only if the reaction confines the ends of the reinforcement; and $\mathbb{M}_{t}$ is the theoretical strength of the cross-section. For $f_{y}$ less than $60 \mathrm{Ksi}$ value of $\mathrm{I}_{d}$ for deformed bars is given in ACI Code ${ }^{2}$ by $0.4 \mathrm{~A}_{\mathrm{b}} \mathrm{f}_{\mathrm{y}} / \sqrt{\mathrm{f}_{\mathrm{c}}^{1}}$. The ACI Code ${ }^{2}$ gives $I_{d}$ to be used at points of inflection limited to the beam depth, d, or 12 bar diameter $\left(12 a_{b}\right)$, whichever is greater. Fig. 2.8 shows the reinforcement development for simply supported beams as required by ACI 318-71 Code. ${ }^{3}$

For negative moment reinforcement, FiE. 2.9 illustrates two methods of satisfying requirements for anchorage of tension bars beyond the face of support. ${ }^{3}$ The anchorage reinforcement is also usuable in brackets as shown in Fig. 2.10.

Tie anchorages are called hooks, which are bent into a 90 degree turn plus an extension of at least 12 bar diameters at the free end of the bar. ${ }^{8}$ The minimum tension embedment of the standard end hooks is given in Reference 8 . 

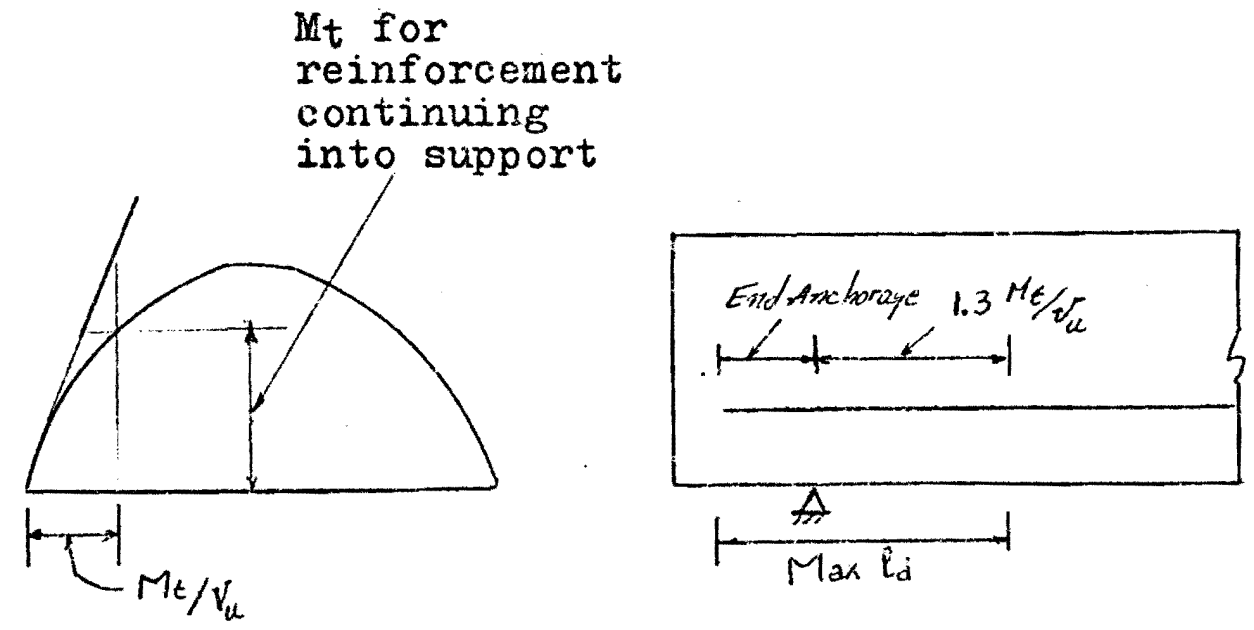

Figure 2.8. Reinforcenent Development in Simply Supported Beams. (From Ref. 3)
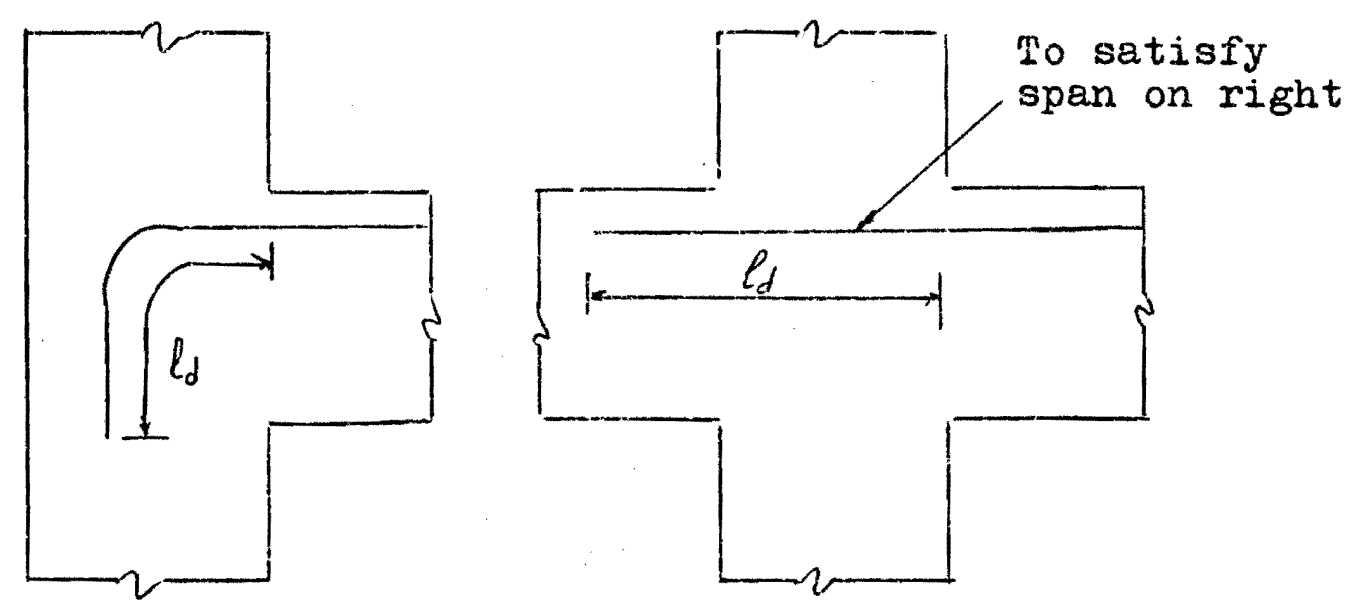

Figure 2.9. Anchorase Kequirement; (a) Anchorage into Exterior Column, and (b) Anchorage into Adjacent Beam. (From Ref. 3) 


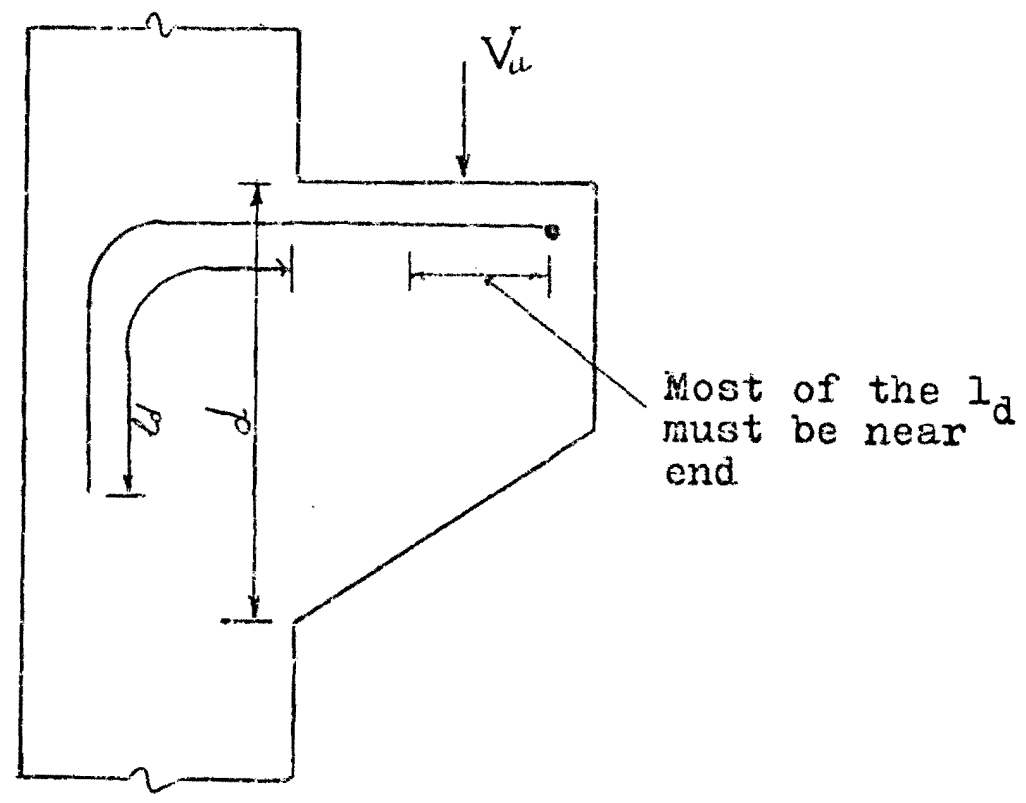

Figure 2.10. A Bracket (Largely Dependent on End Anchorage). (From Ref. 3) 


\subsection{PRESTRESSED CONCRETE}

\subsubsection{Materials and Specifications}

A. Concrete. Concrete used in prestressed members is usually stronger than that used in ordinary reinforced concrete. In the United States, concrete with a strength of 4,000 to 5,000 Psi is generally used for prestressed concrete. $^{14}$ Higher strength is used for several reasons. Commercial anchorages for prestressing steel are always designed on the basis of high-strength concrete, since weaker concrete either will require special anchorages or may fail under the application of prestress. Further, the high strength concrete offers higher resistance in tension and shear, as well as in bond and bearing, which are effectively utilized in prestressed concrete members. ${ }^{14}$ Also, high strength concrete is less liable to the shrinkage cracks which sometimes occur in low-strength concrete before the prestressing. It also causes a smaller loss of prestress in the steel. 14

In order to obtain concrete with a strength of 5,000 Psi, it is necessary to use a water-cement ratio of not more than 0.45 by weight. For fast placing of concrete, a slump of 2 in. to 4 in. would be needed, unless more than ordinary vibration is to be applied. To obtain a 3 in. slump with a water-cement ratio of 0.45 would require about 8 bags of 
cement per cu. yd. of concrete. ${ }^{14}$ Typical stress-strain

curve for 5,000 Psi concrete is shown in Fig. 2.11. 14

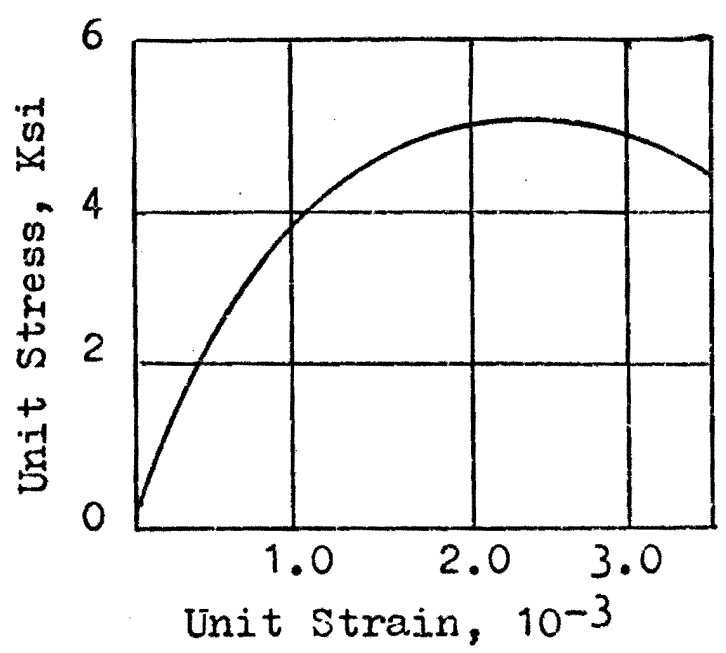

Figure 2.11. Typical Stress-Strain Curve for 5,000 Psi Concrete. (From Ref. 14)

Light weight concrete is becoming more widely used in prestressed concrete. 14 The main reascn is to reduce the weight of the structure, so savings in concrete and steel can be realized. This is especially important when the dead load is the major portion of the load on the structure. Also, weight reduction is desirable in transportation and erection of precast members. The unit weight of light weight concrete varies between 90 to $110 \mathrm{Psf} .^{14}$

There is a special kind of concrete called selfstressing concrete. This concrete is made of a special type of cement that expands chemically after setting and during hardening. When these cements are used to make concrete with embedded steel, the steel is elongated by the expansion of 
concrete. Therefore, the steel is prestressed in tension, which creates compressive prestressing or self-stressed conconcrete. ${ }^{14}$

B. Steel for Prestressing. The most generally used material for producing prestress is hifh-tensize steel, which supplies the tensile force in prestressed concrete. ${ }^{14}$ There are several methods of production of high-tensile steel, such as: alloying by carbons, or quenching or tempering; and cold-drawing of steel bars through a series of dyes. $^{14}$ High-tensile steel for prestressing usually takes one of the following three forms.

1) Steel Vires - Vires for prestressing are again usea to produce the prescribed mechanical properties. ${ }^{14}$

The tensile strength and minimum yield strength (measured by the $2.0 \%$ total-el.ongation method) are shown in Table II. 1 for the common sizes. 14

TABLE II. 1

TENSILE AND YIELD STRENGTH FOR PRESTRESSING WIRES

(FROM REF, 14)

\begin{tabular}{clccc}
\hline \hline $\begin{array}{c}\text { Nom. Diam. } \\
\text { in. }\end{array}$ & Remarks & $\begin{array}{c}\text { Area } \\
\text { Sq. In. }\end{array}$ & $\begin{array}{c}\text { Min. Tensjie } \\
\text { Strength, Fsi }\end{array}$ & $\begin{array}{c}\text { Nin. Yield } \\
\text { point, Psi }\end{array}$ \\
\hline 0.192 & Gage No.6 & 0.02895 & 250,000 & 200,000 \\
0.196 & $5 \mathrm{~mm}$ & 0.03017 & 250,000 & 200,000 \\
0.250 & $\frac{1}{4} \mathrm{in.}$ & 0.04909 & 240,000 & 192,000 \\
0.276 & $7 \mathrm{~mm}$ & 0.05983 & 235,000 & 188,000 \\
\hline
\end{tabular}


A typical stress-strain curve for wires and bars is shown in Fig. 2.12. A constant modulus of elasticity exists only for a limited range (up to about 80,000 Psi) with a value between 25,000,000 and 28,000,000 Psi. ${ }^{14}$

Two of the most common methods of post-tensioning systems are Freyssinet and Magnel, the anchorages of which are manufactured for $5-\mathrm{mm}$ and $7-\mathrm{mm}$ wires. Such wires still possess high strength, and there are fewer units to handle. Therefore, they have become popular and almost monopolize the post-tensioning field. ${ }^{14}$

The Freyssinet system is a post-tensioning system with wires of $0.196 \mathrm{in.}$ and $0.276 \mathrm{in.}$ in diameter. The cables consist of 12 and 18 wires of 0.196 in. in diameter and 12 wires of $0.276 \mathrm{in.}$ in diameter, with an ultimate strength of 90,108 and $136 \mathrm{Ksi}$. Maximum tensile load is $80 \%$ of the ultimate, and maximum design load is $60 \%$ of the ultimate. For more details concerning anchorage dimensions and assembled views, Reference 14 is suggested.

The Magnel system is a post-tensioning system which uses rectangular sandwich plates of steel which have tapered notches to receive the wedges. Wires of $0.196 \mathrm{in}$ and 0.276 in. in diameter are used, with bearing plates that are capable of holding 2, 4, 6 or 8 wires. The number of wires for the Magnel cable varies from 2 to 64 per cable for both sizes of wires. A typical Magnel cable of twenty-four $0.196 \mathrm{in}$. wires consists of 6 layers with 4 wires per layer, which is the most commonly used. 


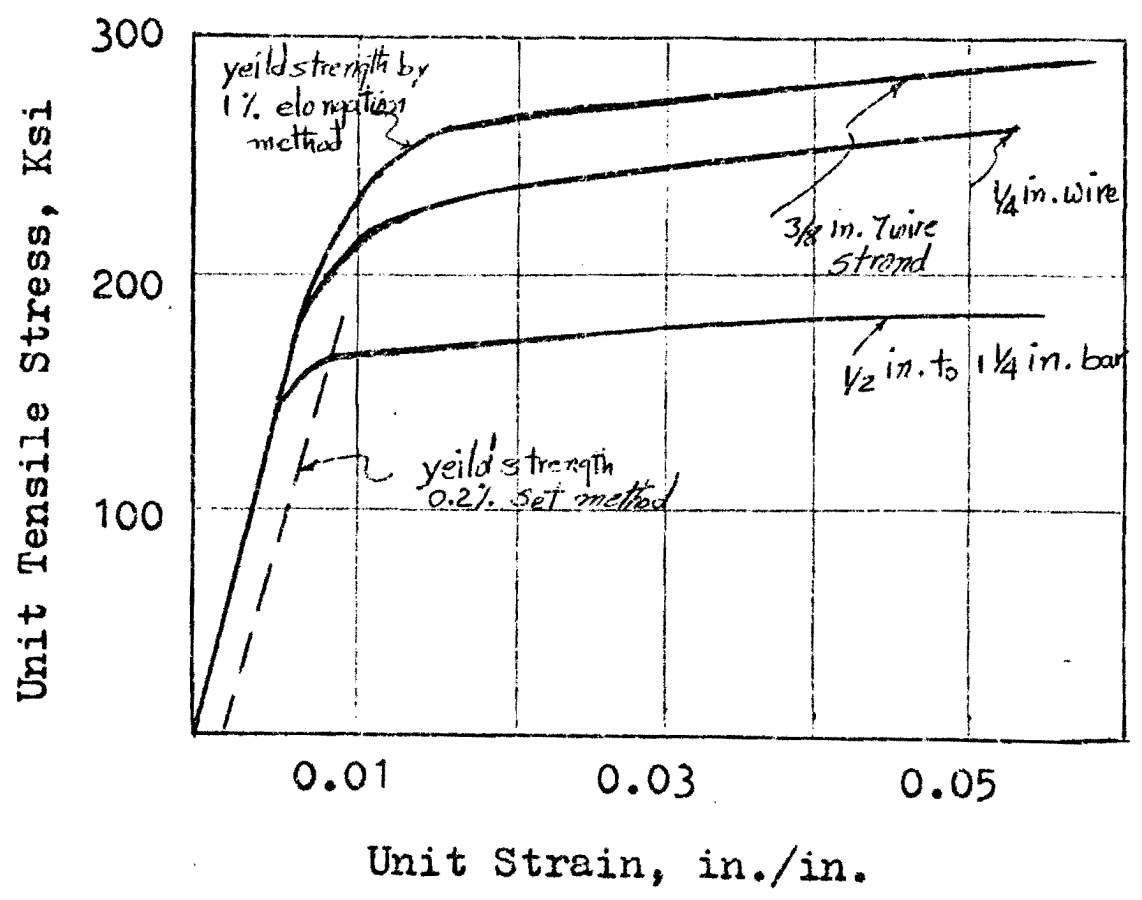

F'igure 2.12. Typical Stress-Strain Curve for Prestressing Steels. (From Ref. 14) 
2) Steel Strand - Strands for prestressing generally conform to ASTM Specification A-416. ${ }^{14}$ This specification is used for both pre-tensioned and post-tensioned construction, whether bonded or unbonded. 14

Seven wire strands, which are generally used for prestressing, conform to the ASTM Specification $A-416$, and have a guaranteed minimum ultimate strength of 250,000 Psi. 14

3) Steel Bars - ASTM Specifications A-322 and A-29 are often applied to high strength alloy steel bars. Ultimate strength of steel bars often reaches 160,000 Psi, and the specified minimum strength is generally. set at 145,000 Psi.

There are also new prestressing tencons called fiberglass tendons, which are made by drawing fluid glass into fine filaments. Although fiberglass tendons have not yet been commercially used in prestressed concrete construction, they do, however, have certain superior qualities such as ultimate tensile strength of 1,000,000 Psi. 14

\subsubsection{Design Concepts}

There are many concepts that may be applied to explain and analyze the basic behavior of prestressed concrete. One of the simplest concepts is to consider prestressed concrete as a combination of steel and concrete similar to ordinary reinforced concrete. Steel supplies a tensile force, and concrete a compressive force, thus forming a ccuple as 
shown in Fig. 2.13. 14

Another concept is to consider prestressing to transform concrete into an elastic material. When concrete, which is weak in tension, is compressed by steel under high tension, it is able to withstand tensile stresses. Since prestressed concrete can carry tensile stresses, it can be said that it is an elastio material such as steel.

To clarify the latter concept, consider a simple rectangular beam prestressed by an eccentric (does not pass through its centroid) tendon, and loaded by extermal loads. The stresses which exist are as follows. Due to prestress force $F$, there is a uniform stress $f=\frac{F}{A}$. Due to $M$, which is the extermal moment due to the applied load and the weight of the beam, there is a stress $\hat{f}=\frac{M y}{I}$. Due to eccentric prestressing, there is moment cqual to $\mathrm{Fe}$, and the stress due to this moment is $f=\frac{\text { Fey }}{\mathrm{I}}{ }^{14}$

The resulting stress distribution is given by $f=\frac{F}{A} \pm \frac{F e y}{I} \pm \frac{M y}{I}$, and is shown in Fig. 2.14. Another concept of prestressed concrete is the load balancing concept. This is to consider prestressing as an attempt to balance the loads on a member. Reference 14 includes a broad discussion of the load balancing concept, and its use in araljsis and design.

2.3.3 Strength and Serviceability Consideration

A. General. In the design of prestressed concrete members, the design investigation should include all load 


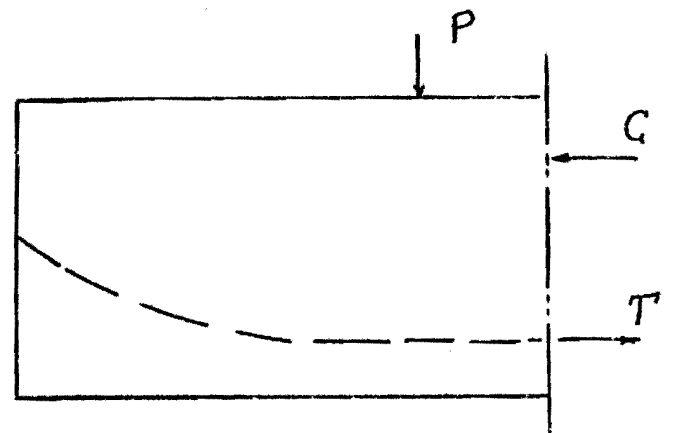

portion of prestressed beam

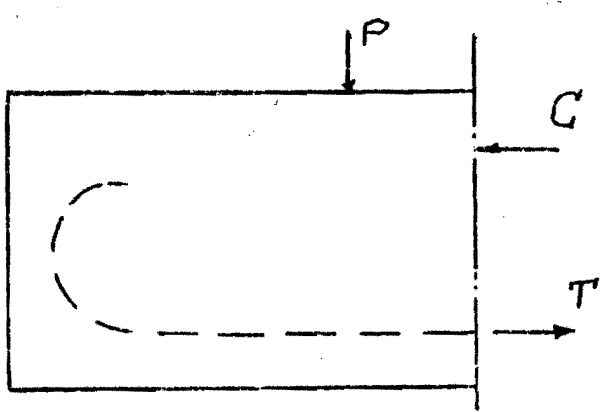

portion of reinforced beam

Figure 2.13. Internal Resisting Monent in Prestressed and Reinforced Concrete.

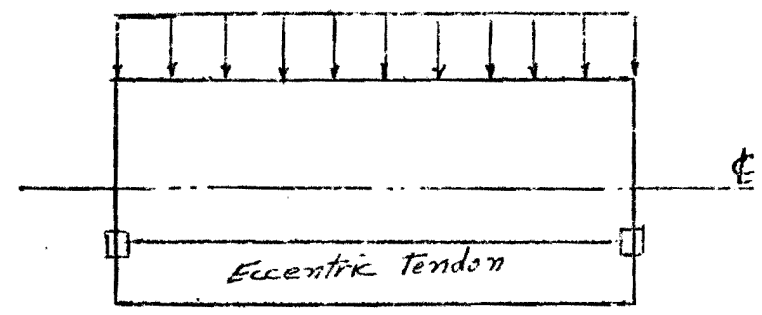

Beam Eccentricity Prestressed and Ioaded

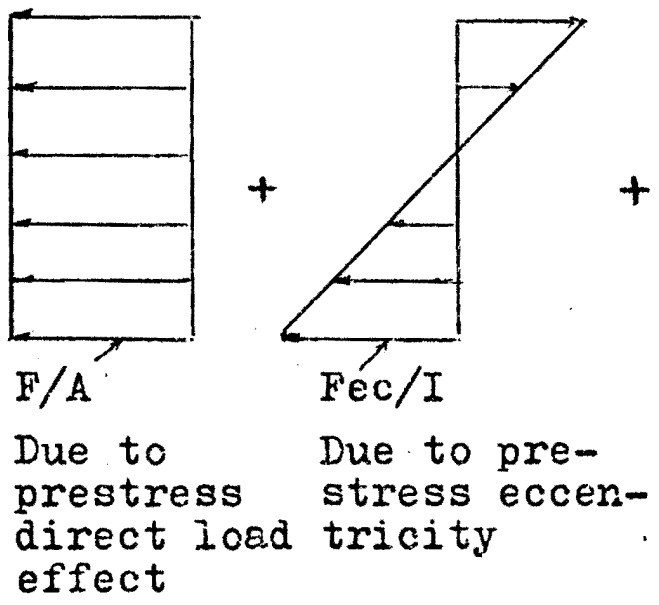

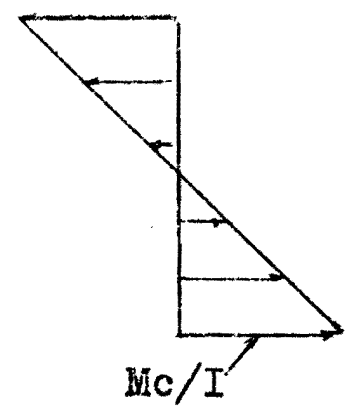

Due to extermal moment MI

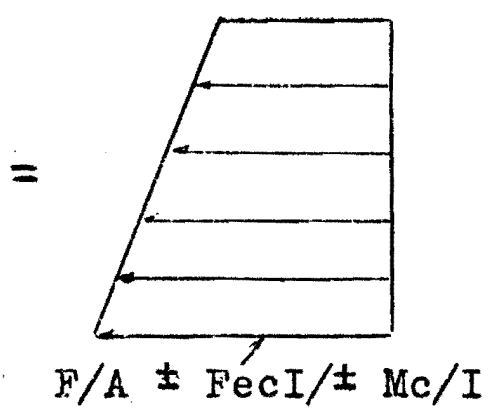

Due to eccentric prestress and extermal moment M

Figure 2.14. Stress Distribution Across an Eccentrically Prestressed Concrete Section. 
stages that may be significant. ${ }^{14}$ The following are the major stages.

1) Initial Stage - At this stage, the member is under prestress, but is not subjected to any superimposed external load. This stage can be further subdivided into the following stages: before prestressing, during prestressing and at transfer of prestress.

2) Intermediate Stage - Ihis is the stage during transportation and erection of members. It occurs only for precast members.

3) Final Stage - This is the stage when the actual working loads act on the member. In this stage, it is often necessary to investigate the members for cracking and ultimate loads. Also, they must be checked for their behavior under the actual sustained load in addition to the working load.

For example, a beam could be prestressed along its longitudinal axis in such a manner that it will support the specified loads without large deflections, but the strength could be below adequate safety requirements. Similarly, a design based on strength alone may provide unsatisfactory behavior at service loads due to excessive camber of deflection. This means that actual design should be based on strength, using load factors and strength reduction factors. Then, an investigation at service load levels is necessary to determine the approximate stresses at service loads. For 
beams without axial loads, the ACI 318-71 Article $18.2^{2}$ recommends the classical straight line theory. For sections with axial load, a general analysis considering the stress-strain diagram for prestressing steel is mostly recommended.

B. Strength. Similar to ordinary reinforced concrete, prestressed concrete members must meet the strength requirements. Design shall be based on strength and on behavior at service conditions at all load stages that may be critical during the life of the member or the whole structure. The margin of safety for prestressed concrete, as for ordinary concrete, is provided ir two ways: load factors and capacity reduction factor $\Phi .^{14}$

C. Serviceability. Prestressed concrete design is more suitable for structures of long spans and those which will carry heavy loads. This is gererally due to higher strengths of materials used. Prestressed concrete members are more slender. They are more adaptable to artistic treatment and give more clearance.

As for ordinary concrete, deflection must be computed and compared to allowable limits for particular loading. Immediate and long-time deflection must be considered. ACI Code Article 9.5.2.4 ${ }^{2}$ specifies deflection as a fraction of span for different types of members.

\subsubsection{Prestressing Systems}

There is a large number of patents for prestressing 
systems in the United States. ${ }^{8}$ The majority of the patents are based on the following two operational details: first, the method of applying the prestress; and secondly, the details of end anchorages. The success of each system generally depends on its economy and convenience.

There are two general methods of stressing the members. The first is pre-tensioning. To pre-tension the member is to pull the tendons between two bulkneads anchored against the ends of a stressing bed. After the concrete hardens, the tendons are cut from the bulkheads in order to transform the prestress to the concrete. The second method of prestressing the members is by post-tensioning, which is to pull the steel against the hardened concrete. There are three major metrods of posttensioning: first, mechanical prestressing by means of using jacks, which is mostly used; secondly, electrical prestressing by application of heat; and, third, chemical prestressing by means of expanding cement. 8 


\section{CHAPTER III}

\section{DEVELOPMENTS IN THE USE OF PRECAST \\ CONCRETE UNITS FOR BUILDIITGS \\ IN THE UNITED STATES}

\subsection{INTRODUCTICN}

Between 1960 and the year 2000 , it will be necessary to build more structures in the United States than have been built from the time the Pilgrims arrived until 1960. 18 According to the U. S. Govermment figures, by the year 2000 , some $80 \%$ of all Americans (more than today's entire population) will be city dwellers. Accordingly, the number of structures also must increase in the same order.

Precast concrete units are playing an important role in such construction. Advantages of precast concrete construction include: availability of materials; rapid construction without delays due to inclement weather; earlier occupancy with savings on interest for construction loans; superior fire resistance with additional savings on insurance premiums; repreated use of identically designed structural components with evident advantages for the contractor as well as the designer; and flexible design opportunities.

Since most structural concrete members are prestressed, they can be designed for longer spans for areas 
unhampered by columns. An additional advantage of precast concrete construction is the early creation of a working deck without the necessity of scaffolding. These members also may be finished rapidly with less expense, merely by painting or trrough direct application of plaster, without the use of forms or dropped ceilings.

Precast concrete floor systems can be adapted or designed to include an integrated utility system. The floor units can serve as casing for plumbing, heating and ventilation, and electrical and telephone utilities, thus providing additional flexibility of design.

Developed methods in design and analysis of precast concrete members for both flexure ana compression members are presented in Section 3.2. Connection designs are described in order of their importance in detail in section 3.3. Section 3.4 is devoted to sealant materials and joint details. Fire resistance of precast concrete members is described in section 3.5. In section 3.6, three case studies on recently built structures using precast concrete units are discussed. 


\subsection{PRECAST CONCRETE UNITS}

\subsubsection{Beams}

Beams are designed and manufactured in different shapes and sizes. The most commonly used shapes are rectangular beams, single-Tee beams, double-Tee beams, inverted beams, I shaped beams and, for stronger members, girders. Typical cross-sections of the above beams are shown in Figs. 3.1 through 3.6.17

Typical steps which may be taken in designing the precast prestressed corcrete flexure members are: ${ }^{17}$

1) Select a section available near the project location.

2) Select the number and size of strands and the eccentricity of the beam at mid-span and at the ends (controlling points).

3) Investigate stress conditions at the critical sections.

4) Check ultimate moment capacity. The strain compatibility method suggested by ACI $318-71$ Code $^{2}$ can be used. Also, the following equations given by the PCI Handbook ${ }^{6}$ may be used:

$$
\begin{aligned}
& M_{u}=\Phi\left[A_{p s}{ }_{p s}^{d}\left(1-0.59 w_{p}\right)\right] \text { whexe } w_{p}=\frac{A_{p s}}{b d} \frac{f_{p u}}{f_{c}} \\
& M_{u}=\phi\left[A_{p s} f_{p s}(d-a / 2)\right]
\end{aligned}
$$




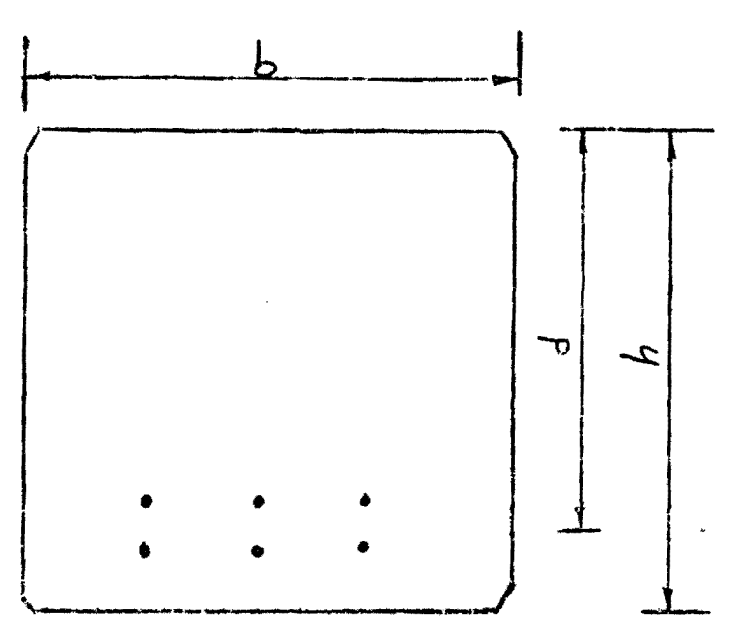

Figure 3.1. Rectangular Beam Cross-Section.

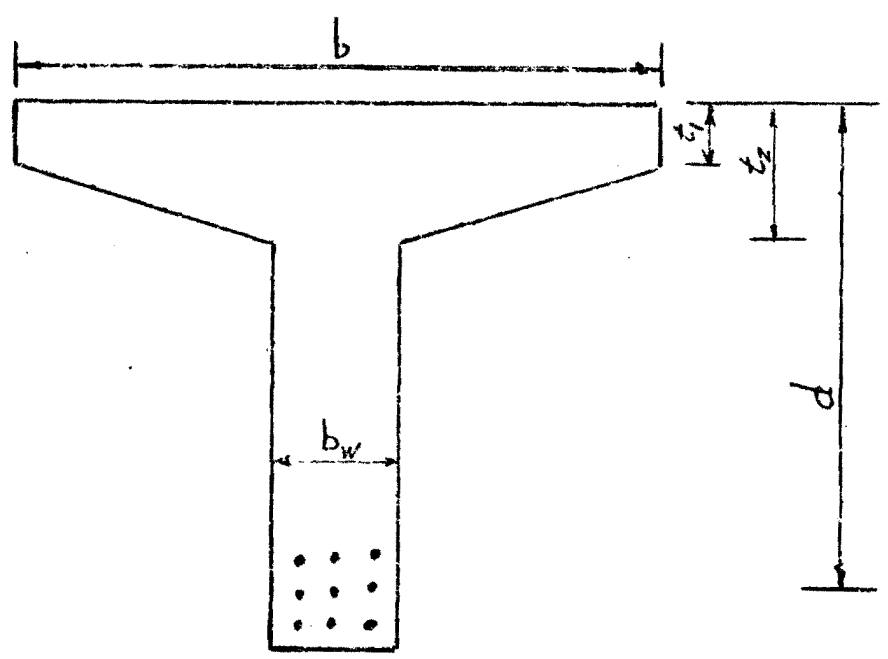

Figure 3.2. Single-Tee Beam Cross-Section.

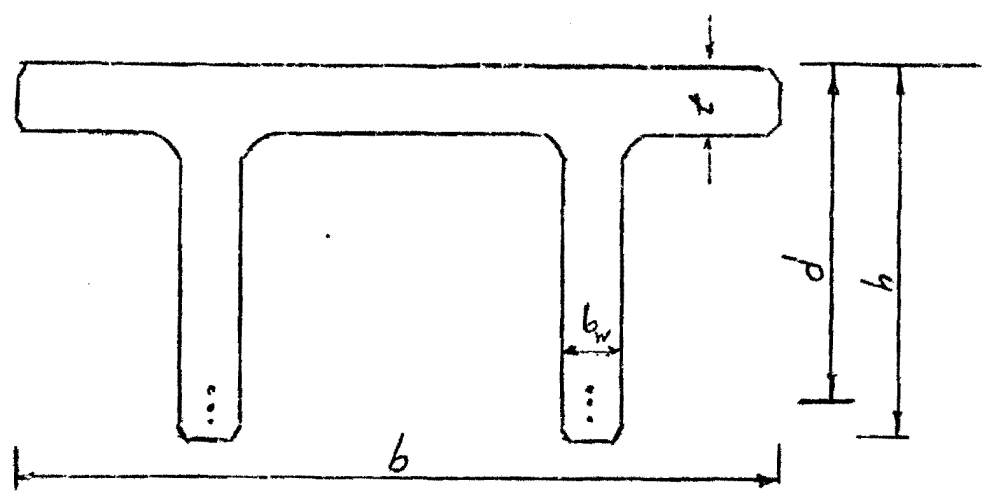

Figure 3.3. Double-Tee Beam Cross-Section. (From Ref. 17) 


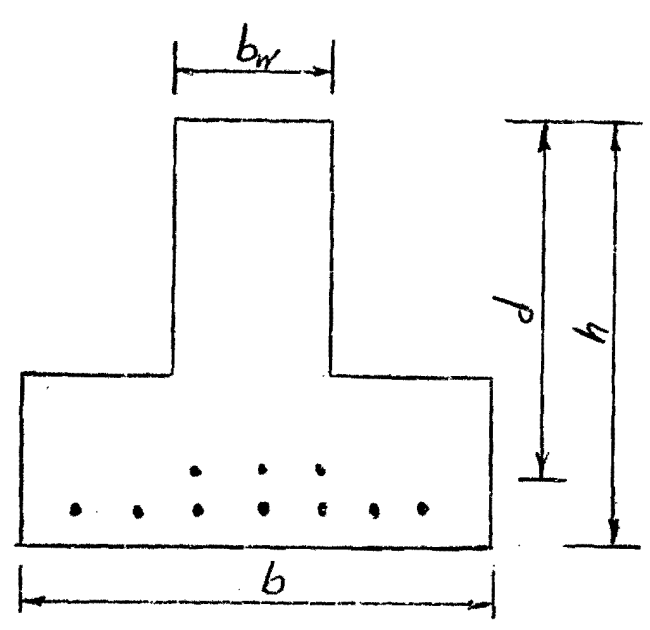

Figure 3.4. Inverted Tee Beam Cross-Section. (From Ref. 17)

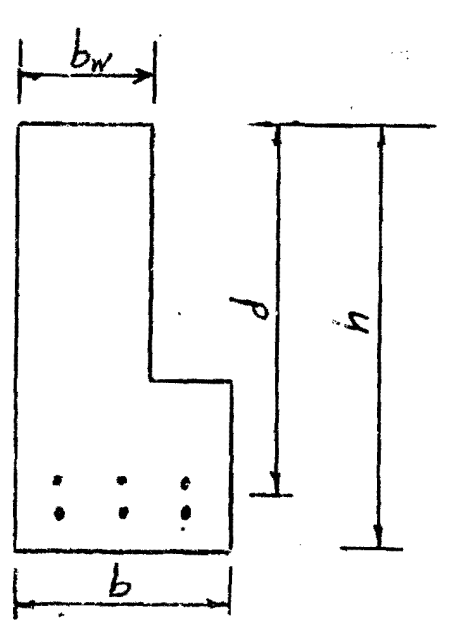

Figure 3.5. I-Shape Eeam Cross-Section. (From Ref. 17)

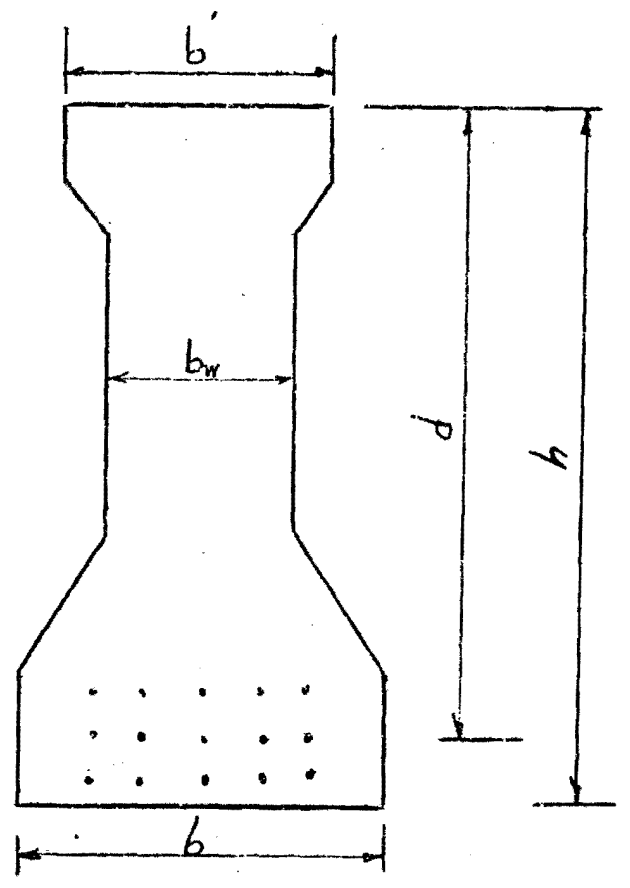

Figure 3.6. Girder Beam Cross-Section (Usually called AASAO). (From Ref. 1\%) 
Aids (Figs. 5.2.1 through 5.2.7) are provided for this purpose in the PCI Handbook. ${ }^{17}$ The critical section for checking ultimate capacity is the same as for service load stresses.

5) Steps (1) and (2) should be modiried in order to obtain the most economical section.

6) Carnber and deflection should be checked by conventional moment-area equation as shown below:

$a_{i}=\frac{5}{384} \frac{W L^{4}}{E_{c}}$ for deflection

Initial camber $=\frac{P_{e L^{2}}}{8 E_{c i}} \pm \frac{4 P_{e} I^{2}}{48 E_{c i}^{I}}=\frac{P L^{2}\left(3 e+2 e^{\prime}\right)}{24 E c I^{I}}$

7) Check for cxitical shear stress. For most deck sections, only minimum or no shear reinforcement is required, in accordance with section 11.1 .1 of ACI $318-71 .^{2}$ Table 5.2.14 in the PCI Handbook can be used for shear check. ${ }^{17}$

In lieu of a more precise determination of $f_{p s}$ based on strain compatibility, and, provided that $f_{\text {se }}$ is not less than $0.5 f_{p y}$, the following approximate values can be used: $f_{p s}=f_{p u}\left(1-0.5 \rho_{p} f_{p u} / f_{c}^{\prime}\right)$ for bonded merbers, where $P_{p}=\frac{A_{s p}}{b d}$. Tables are provided in the PCI Handbook ${ }^{17}$ for both bonded and unbonded prestressing steel.

\section{$\underline{3.2 .2 \quad \text { Slab }}$}

Slab systems may be designed by any procedure satisfying the conditions of equilibrium and geometrical compatibility. It is necessary that both strength and service- 
ability conditions be met. ${ }^{2}$ The usual procedure to design a one-way prestressed slab is to consider a typical 1-ft. width of slab. Whether the slab is simple, cantilever or continuous, it is designed like a beam. Although the main prestressing steel runs along the length of the slab, transverse steel, either prestressed or not, must be added for shrinkage stresses and to distribute any concentration of loads. Most of the precast concrete slabs have a hollow core. The hollow coxe is provided to decrease the weight, and save in materials without much loss of stiffness or strength. The PCI Design Handbook ${ }^{17}$ provides the section properties for different shapes of hollow-core slabs used in the United States. Two typical cross-mections of hollowcore slabs are show in Figs. 3.7 and 3.8 .

Fig. 3.9 shows typical load-span curves for hollowcore slab. The PCI Design Handbook contains curves that show the span and load ranges for various depths of hollowcore slabs available in all areas in the United States. The loads shown are based on the provisions of the ACI 318-71 code. $^{2}$ The maximum span to depth ratio of 50 is used for roofs and ratios above 40 (shaded areas) are not recommended for floors as show in Fig. 3.9.

The curves indicate the rance of safe load capacity for a given span, and may be used to tentatively select the depth of a hollow-core unit. Upper and lower limits of the load-span bands are the maximum and minimum amounts of pre- 


$$
4 \cdot-0 " \times 8 "
$$

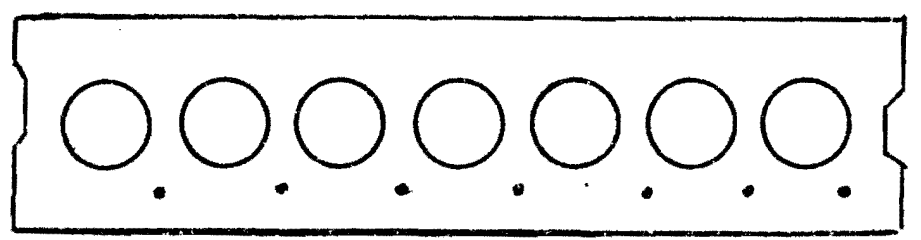

Figure 3.7. Dynaspan Hollow-Core Slab. (From Ref. 17)

$$
4 \text {-0" } \times 8 \text { " }
$$

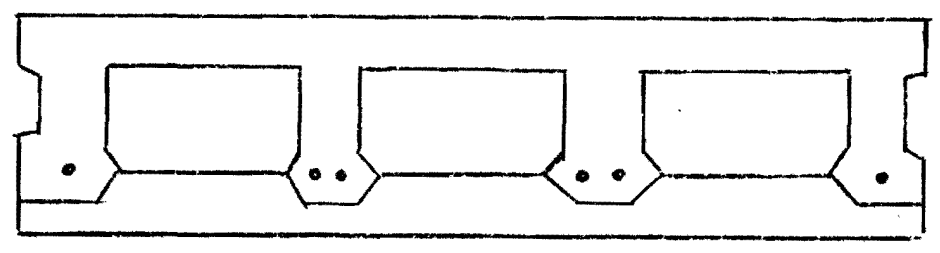

Figure 3.8. Span-Deck Hollow-Core Slab. (From Ref. 17) 


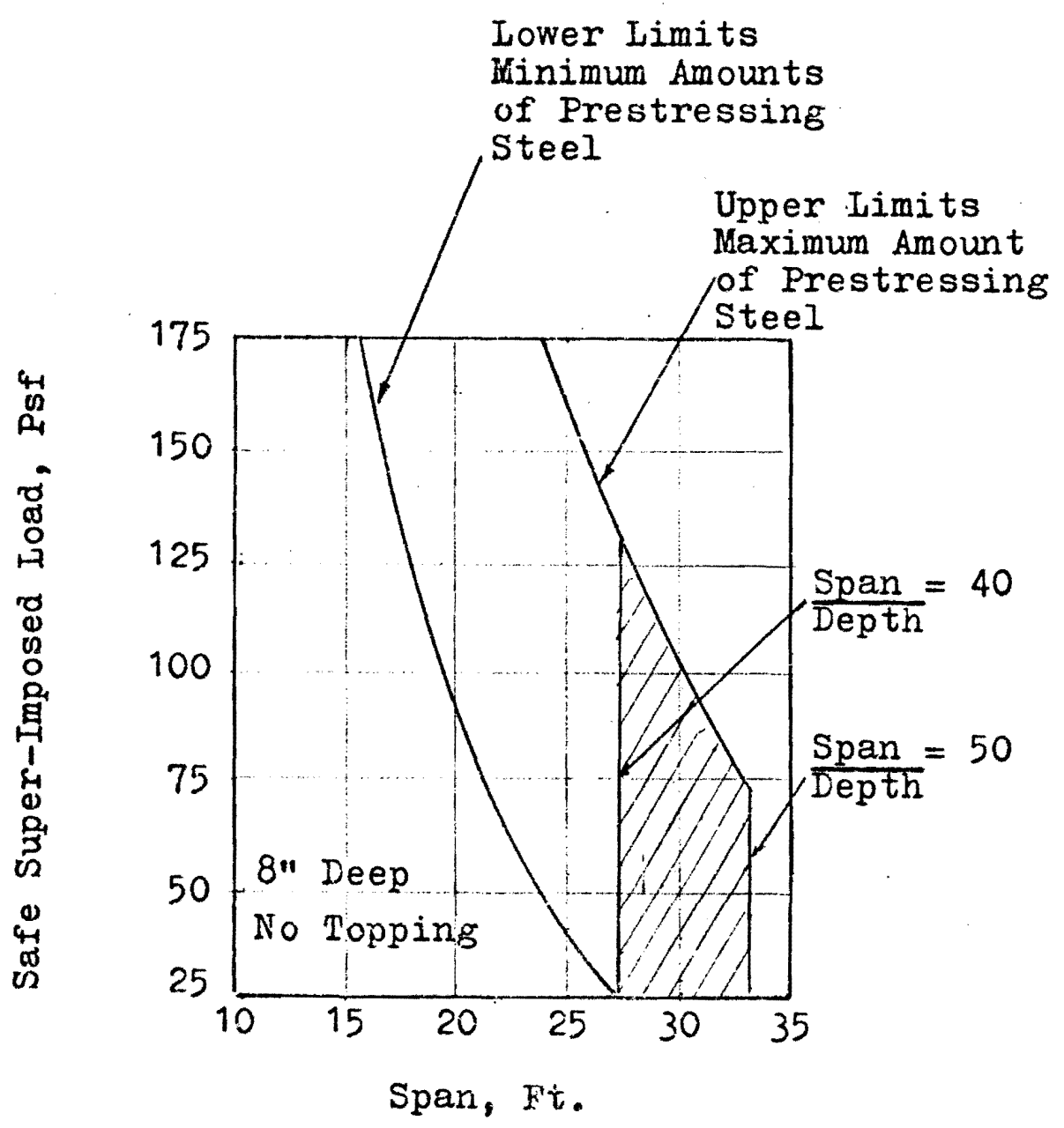

Figure 3.9. Typical Load Span - Curves for 8" Deep No Topping Hollow Core Slab. (From Ref. 17) 
stressing steel usually used. 17

\subsubsection{Columns}

Precast concrete columns, both ordinary and prestressed, are used in building construction in the United States. The tendency to increase the use of precast prestressed concrete over ordinary reinforced columns is due to the fact that prestressing improves elastic behavior and handling characteristics of the columns, and increases its resistance to lateral forces, both in the elastic and the ulimate ranges. 17

The stress at any section in elastic analysis for a prestressed column under eccentric load is given by the equation $f_{\max }=-\frac{F}{A}-\frac{P}{A} \pm \frac{P e c}{I} \pm \frac{P \Delta C}{I}$, where critical stresses generally occur at the mid-height of the column. The deflection can be obtained by the Secant Furmula as $\Delta=e\left(\operatorname{Sec} \sqrt{\frac{P_{L}^{3}}{4 E_{c} I_{t}}}-1\right) \cdot 10$

Using ultimate strength design, column capacities can be obtained on stress and strain compatibility as described in Chapter 10 of ACI 318-71 Code $^{2}$, discussed in Chapter 2, Section 2.3 .2 of this thesis. The capecity reduction factor $\Phi$ should be included. Slenderness effects should be considered when designing columns, as required in Section 10.10 of ACI 318-71 Code. ${ }^{2}$

Tables 3.4 .2 and 3.4 .3 in the PCI Design Hanabook ${ }^{6}$ provide the ultimate allowable axial loads and moments for square prestressed columns. 2 Also, the design aids con- 


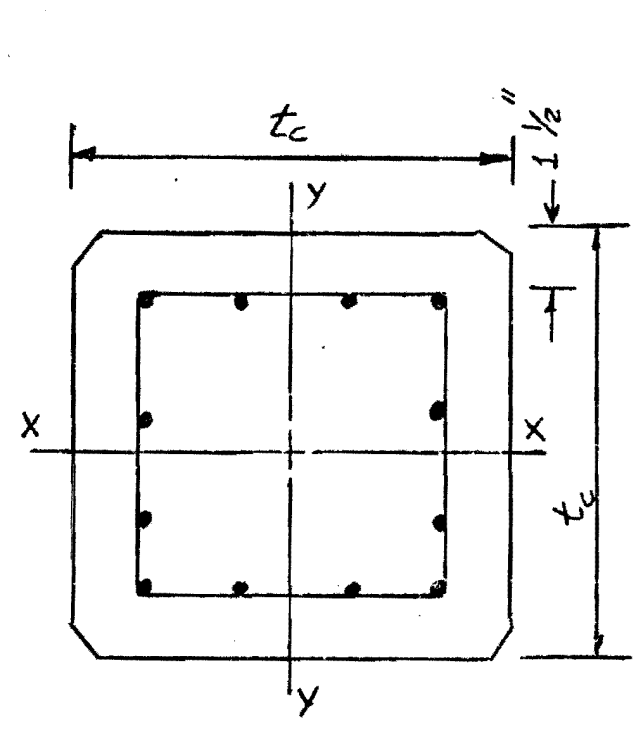

Figure 3.10. Rectangular Cross-section. (From Ref. 17)

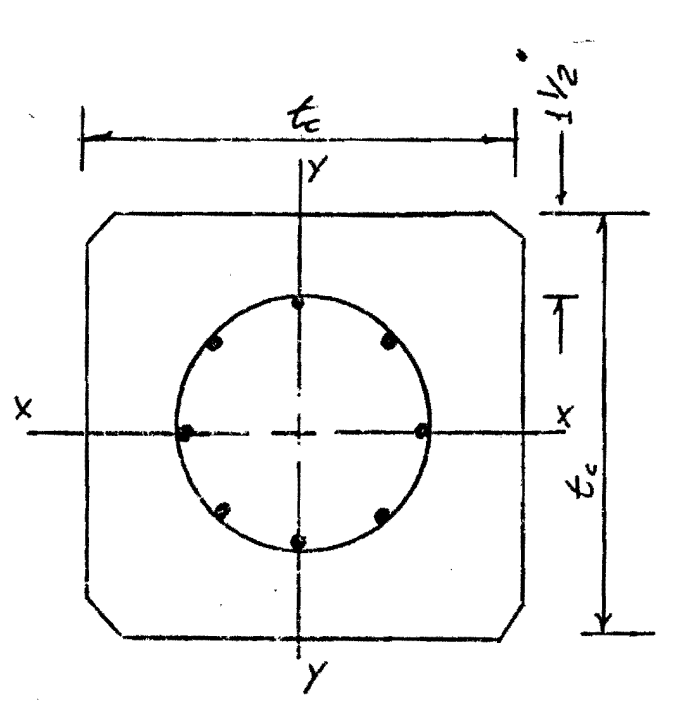

Figure 3.11. Rectangular Cross-section, Spirally Tied. (From Ref. 17)

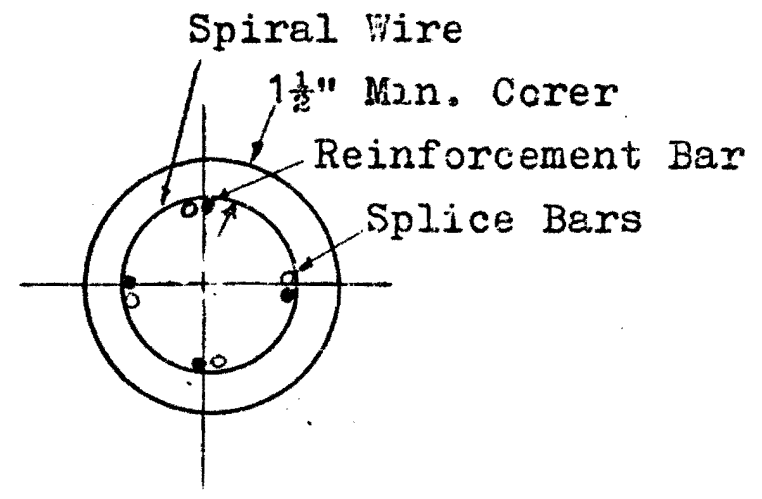

Figure 3.12. Typical Round Column with Spiral Wire. (From Ref17)

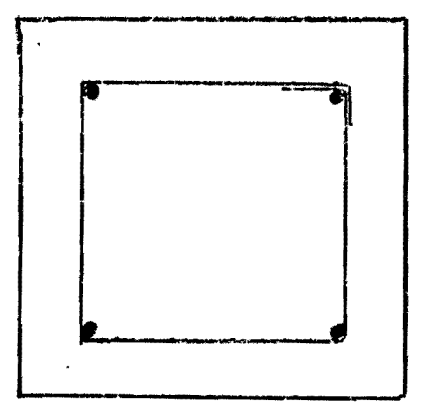

Figure 3.13. Typical Square Column with 4bars and tie. (From Ref. 17) 


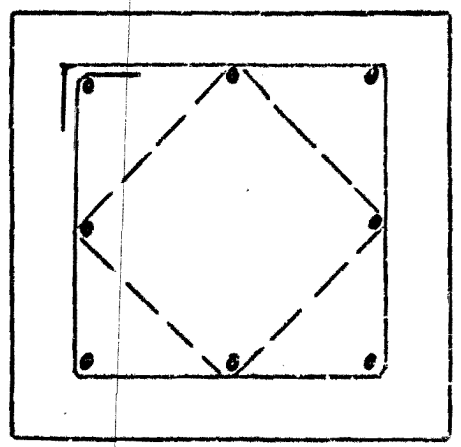

Figure 3.14. Square Column with 8-Bars and ties. (From Ref. 4).

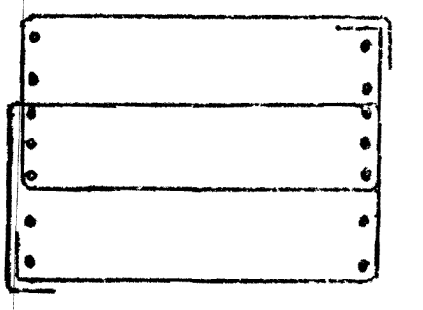

Figure 3.16. Typical Rectangular Column with 14-Bars. (From Ref. 4)

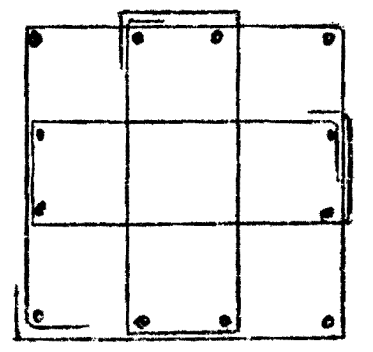

Figure 3.15. Square CoIumn with 12-Bars and pies. (From Ref. 4)

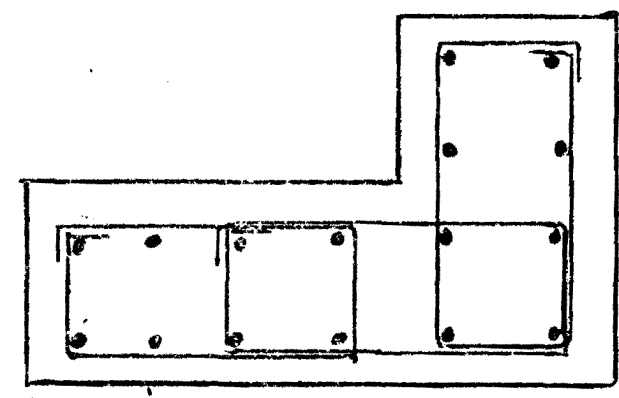

Figure 3.17. Typical Arrangement of Corner Columns. (From Ref. 4) 
cerming slenderness effects are presented in Part 5 of the same handbook. Figs. 3.10 and 3.11 show two typical crosssections for precast concrete columins.

Figs. 3.12 through 3.17 illustrate some of the typical cross-section details of column, as suggested in the Manual of Standard Practice for Detailing Reinforced Concrete Structures. 4

\subsubsection{Wall. Panels}

The precast concrete panel field has grown rapidly in the last few years. Iimited use of panels started prior to 1912, when units were cast at the job site and lifted into place. Similar methods were used for several housing developments and buildings of various occupancies built between 1912 and 1940.6

More recent developments of precast concrete wall panels have involved the use of a variety of surface treatments, such as exposed aggregates, mosaic, glass and marble chips, as well as textured and smooth surface finishes that are obtained by the application of industrial techniques developed in the precast industry. ${ }^{17}$

A variety of shapes have become popular in the field of precast wall panels in the past 10 years. The windowtype mullion wall panel is common in the curtain walls used on many high rise structures today. In many cases, this type of precast wall panel.is replacing the metal curtain wall on the basis of aesthetics and economy. In many cases, 
the designer now has a material that can be molded in any conceivable shape made in precast concrete. 6

While a wide variety of shapes are available, most wall panels can be catagorized as flat panels, double-Tee, ribbed panels, hollow-core panels, window panels or sandwich panels. These six basic types of panels can all serve as curtain wall or as load bearing wall. 6

1) Plat Panels - Flat panels are used ranging from small pieces to large curtain or load bearing walls supporting one or more floors. Many types of buildings use both one story panels and multi-story panels. These panels have haunches or other types of eccentric supports to carry the intermediate floor or roof loads.

Flat panels with a thickness of 4-in. or more lend themselves to prestressing when they car be designed with a concentric prestress of about 200 to 400 Psi. Short flat panels of thin sections are often reinforced with mild steel rather than prestressed when stresses due to handing are rather low. Fig. 3.18 shows a typical flat panel.

2) Double-Tee Panels - A double-Tee panel is an adaptation of a structural member, commonly used in floor or roof systems. When used as a wall panel, the double-Tee is usually concentrically prestressed. Dcuble-Tee load-bearing panels often have haunches cast on the flange face to support intermediate floor members. The haunch can either be the entire width of the panel, or cast as two single 
haunches at the position of the panel legs or stems. Fig. 3.19 shows the typical double-Tee panels.

3) Ribbed Panels - A ribbed panal is similar to a double-Tee wall panel with no openings, but is stiffened by casting muliions or ribs. The flat portion of the ribbed panel is often thicker, usually from 4 to 6 inches.

Depending on tine design and the available plant facilities, ribbed panels may be prestressed or reinforced. Ribbed panels serve as either curtain or load bearing walls. A common use of ribbed panels is for industrial or commercial buildings whexe no windows are required, but an attractive architectural facade is desired. Fig. 3.20 shows typical ribbed panel sections.

4) Hollow-Core Panels - These panels are made by casting hollow cores within the thickness of the panels. The hollow cores of the panels are used for connection purposes. Steel bars are installed through these cores, continuously through the panels on the top and then filled with concrete or grout. Also, bent bars from floor slabs are placed in the hollow cores, and then grouted to create connections.

When these panels are subjected to loads requiring transfer of shear between two faces of the panel, the thickness of connecting diaphragms should be designed for shear transfer through the concrete section. Fig. 3.21 shows typical hollow-core panels. 

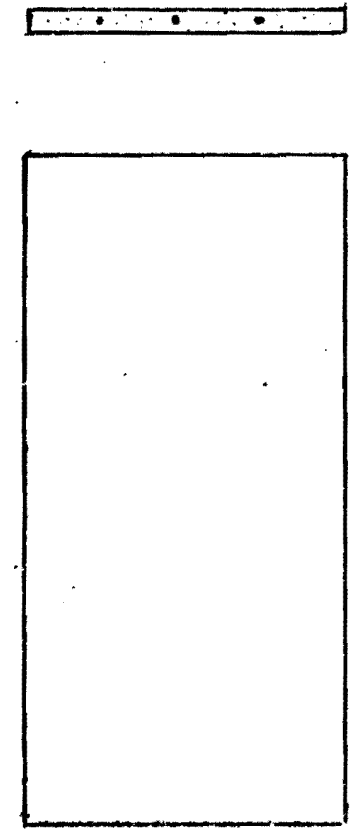
$\frac{\text { Figure } 3.18}{\text { (From Ref. T7) }}$ Typical plat Panel Cross-Section.
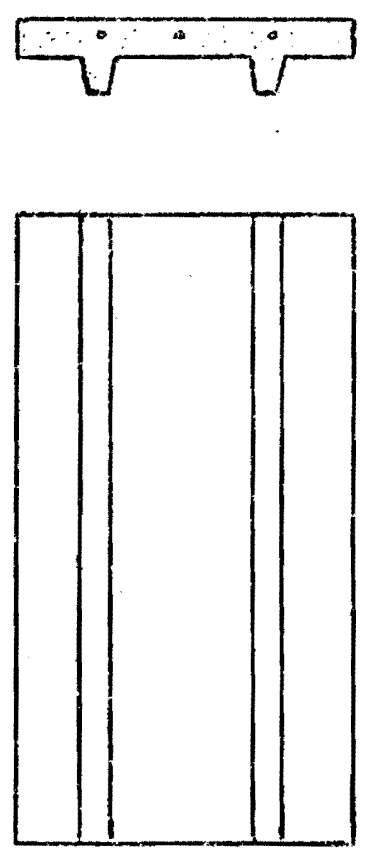

Figure 3.19. Common Type of Precast Double-Tee Viall Panels. (From Ref. 17) 


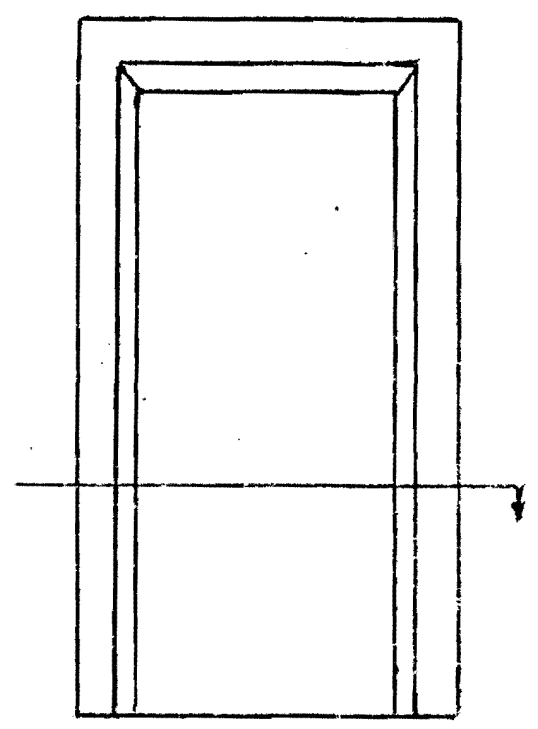
Figure 3.20. Typical Ribbed Panel Section. (From

$$
000000
$$

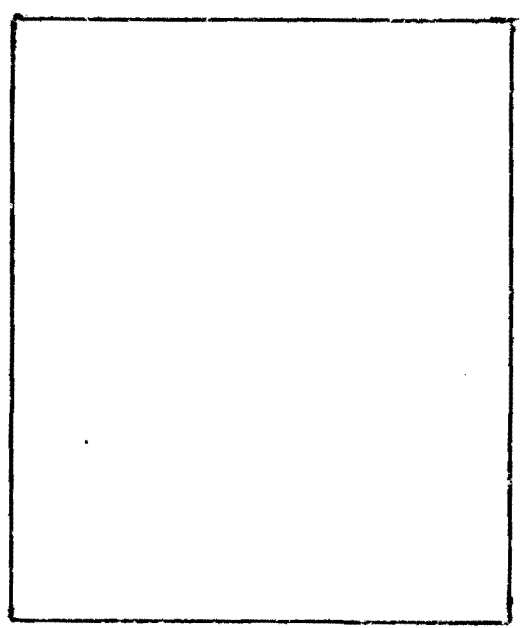
$\frac{\text { Figure } 3.21}{\text { (From Ref. }}$ i7) Typical Hollow Cored Panel Section. 
5) Window Panels - The window, or mullion panels are the most complex type of panel to design. However, they are usually made for specific projects. They require a thorough structural analysis for production, handling, erection and resistance to working loads. Due to the form requirement and difficulty in obtaining concentric prestress forces, prestressing of window panels may not be practical. 17

Window panels can be either single story or multistory. Multi-story panels can be built in any length as long as the handling and transportation problems can be solved. The most practical length of multi-story panels is $45 \mathrm{ft}^{17}$ Fig. 3.22 illustrates a typical two story window panel.

6) Sandwich Fanels - Concrete sandwich panels have become an important feature in modern building construction, as they offer, in a single building element, an economical method of providing structural requirements, thermal insulation and attractive architectural treatment. Extremely light-weight insulating materials such as foamed concrete, plastics and glass provide good insulation, but they have low resistance to handling and service loads. A protective or load-bearing structura]. concrete shell must be provided over one or both sides of these materials. Attractive surfaces may be obtained by many methods, such as exposed aggregate or patterns obtained from three dimensional forms. 6 


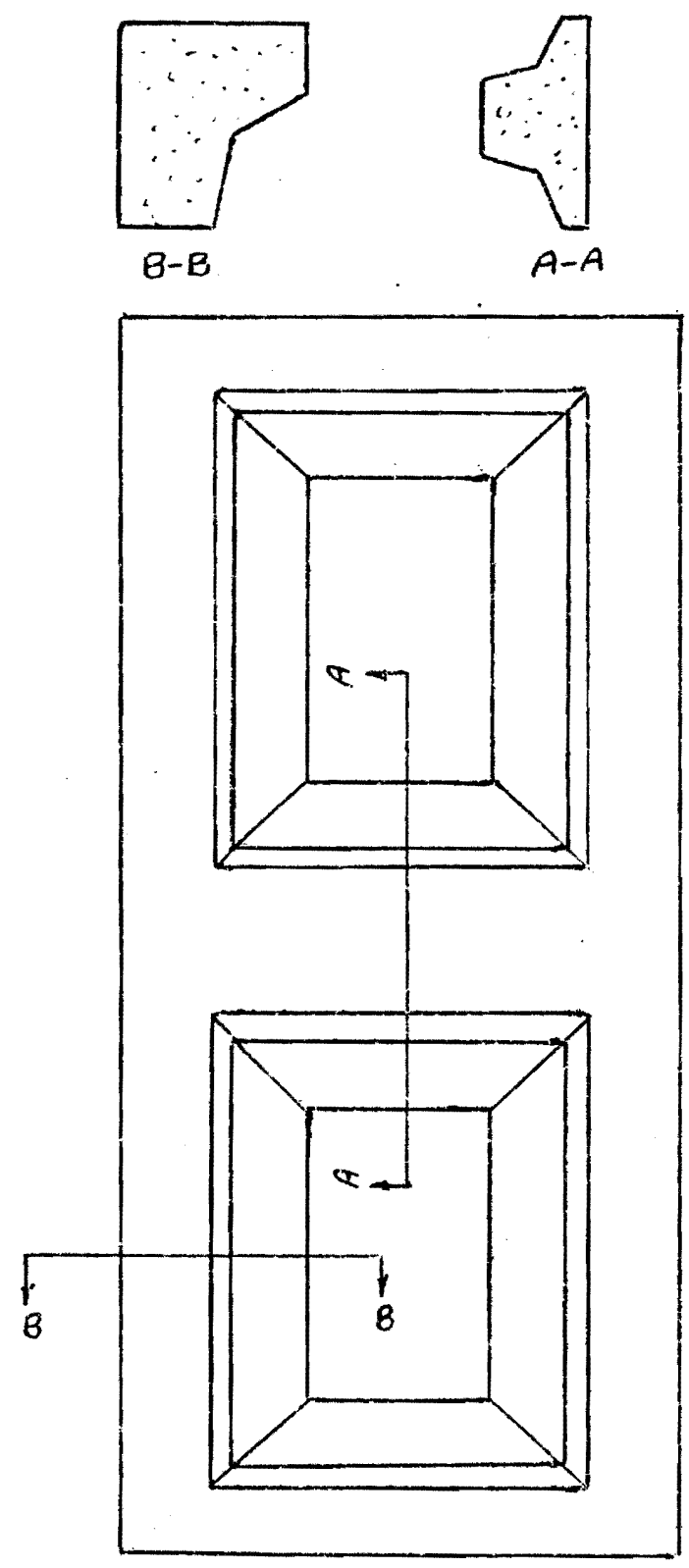

Figure 3.22. Typical Two-Story Window Wall Panels. (From Ref. 17) 
Sandwich panels used in the United States generally have 1 to 2 inches of insulation sandwiched between two identically sized shells which are $1 \frac{1}{2}$ to $2 \frac{1}{2}$ inches thick. Fig. 3.23 shows a typical sanäwich panel cross-section. The design of precast wall panels should be made either with reference to allowable working stresses, service loads and the accepted straight line theory of flexure (working stress design) or with reference to load factors and strength (ultimate strengti design) as given in ACI 31871 Code. $^{2}$

The absence of recognized published data on specifications for precast concrete materials urged the Technical Activities Comnittee of the American Concrete Institute to establish Committee 53.3 Precast Panels. The first organizational meeting was held at the $58 \mathrm{th}$ Annual Convention of the American Concrete Institute in Denver in Vilarci, 1962. ${ }^{6}$ The design method suggested by the ACI Committee 533 is working stress design.

Precast wall panels are divided into two categories: panels used as bearing walls or columns loaded in the plane of the panei, and panel used as beams loaded in the plane of the panel.

In the first category, the aliowable direct compressive stress in the concrete for concentric loads, based on working stress design, should not exceed the following for normal weight concrete, $F_{a}=0.2 f_{c}^{\prime}\left[1-\left(\frac{h}{40 t e}\right)^{3}\right]$. This 

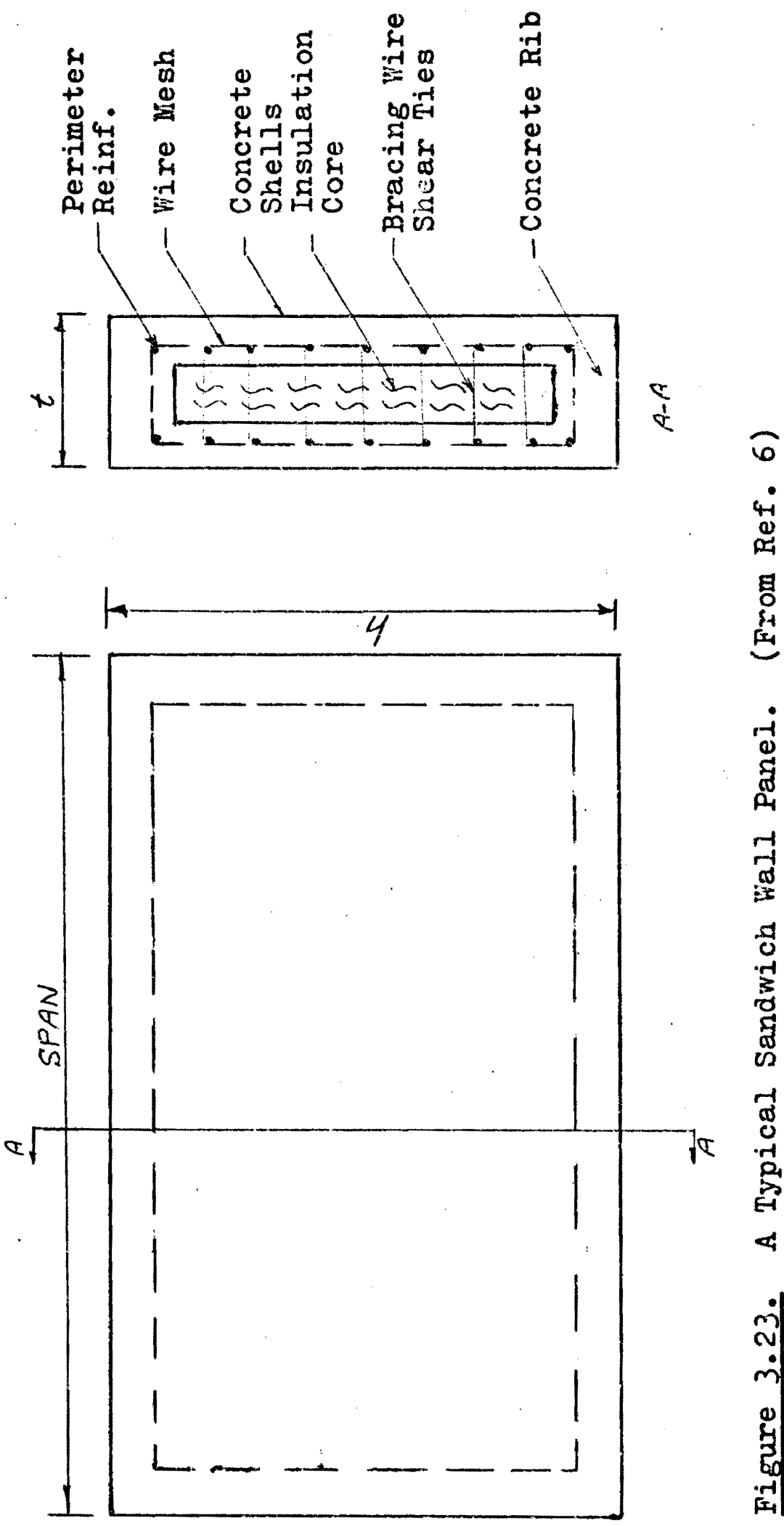

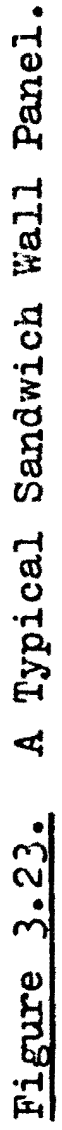


equation is plotted for different $f_{c}^{\prime}$ values in Fig. $3.24 .^{6}$

In the second category, the allowable compressive stress in concrete walls which span horizontally as beams between columns, supports or isolated footings, shall not exceed the following for normal weight concrete (145 Psf), $F_{c}=0.2 f_{c}^{\prime}\left[1-\left(\frac{h}{60 t e}\right)^{3}\right]$, where height of panel $h \leqslant 8 \mathrm{ft} .6$ The above equation is plotted for different $f_{c}^{\prime}$ values in Fig. 3.24.

Precast wall panels used as non-bearing or curtain walls should be limited to $\frac{h}{t}$ (height or span to total thickness) ratio of 50 , provided that the walls are designed to carry all loads which may be imposed on the unit and further provided that the deflection nomal to the plane of the panel under loads is less than $\frac{h}{240}$, but not greater than 3/4in., where $h$ is the distance between supporting or enclosing nembers.

Where ceilings, floors and partitions intersect precast wall panels, the deflection normal to the plane of the panel as well as in its own plane shoula be limited to $\frac{h}{360}$ or $\frac{1}{4}$-in. maximum, or provisions shoula be made for panel movement and deflection in joints.

Precast wall panels spanning between columns, isolated foundations or other supporting members with depth/span ratios greater than $2 / 5$ for continuous spans, or $4 / 5$ for simple spans, should be designed as deep beams, taking into account the non-linear stress distribution and local buck- 


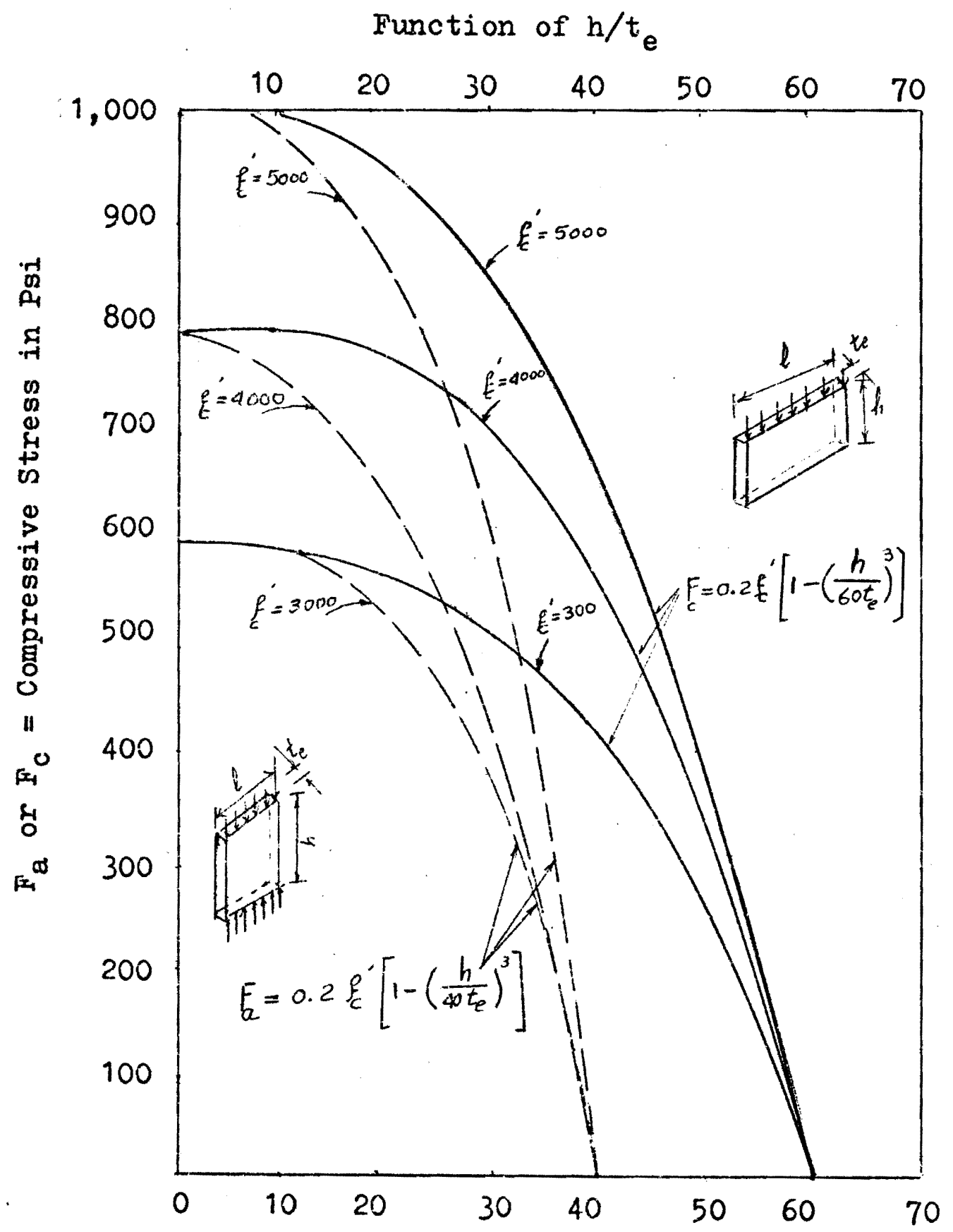

Figure 3.24. Allowable Compressive Stress for Precast Concrete Panels Based on $h / t_{e}$ Ratio, Recommended by ACI Committee 533. (From Ref. 6 ) 
ling (especially in sandwich-type panels).

The clear distances between lateral supports of a precast wall panel should not exceed 32 times the least width of the compression flange or effective panel thickness. 6 Ultimate design relationships for flexural, axial and combined axial-flexural loadings vary for non-rectangular sections. Fig. 3.25 and Fig. 3.26 illustrate the ultimate design relationships for both reinforced and prestressed concrete panel cross-sections. ${ }^{17}$ The unsymmetrical crosssection is chosen for illustration in order to be more general. The prestressed design relationships shown are for concentric prestress about the center of gravity of the precast cross-section, but can be used with little loss of accuracy for eccentrically prestressed cross-sections. 17

In Figs. 3.25 and 3.26 , the design relationships for combined axial and flexural ultimate loadings are referenced to the position of the neutra]. strain axis. The location of the neutral strain axis at ultimate can be determined from $C=\frac{a}{K_{1}}$, where $K_{1}=0.85-0.05\left(f_{c}^{\prime} / 1000-4\right)$, but not greater than 0.85 , for $f_{c}^{\prime}=4000$ Psi.

The principles of ultimate strength design used for ordinary reinforced concrete sections can be applied to prestressed sections with some adeitional consideration. It is necessary to use strand stress-strain curves since prestressing strands do not have the well aefined yield points of mild steel reinforcement. Unless the strand rup- 


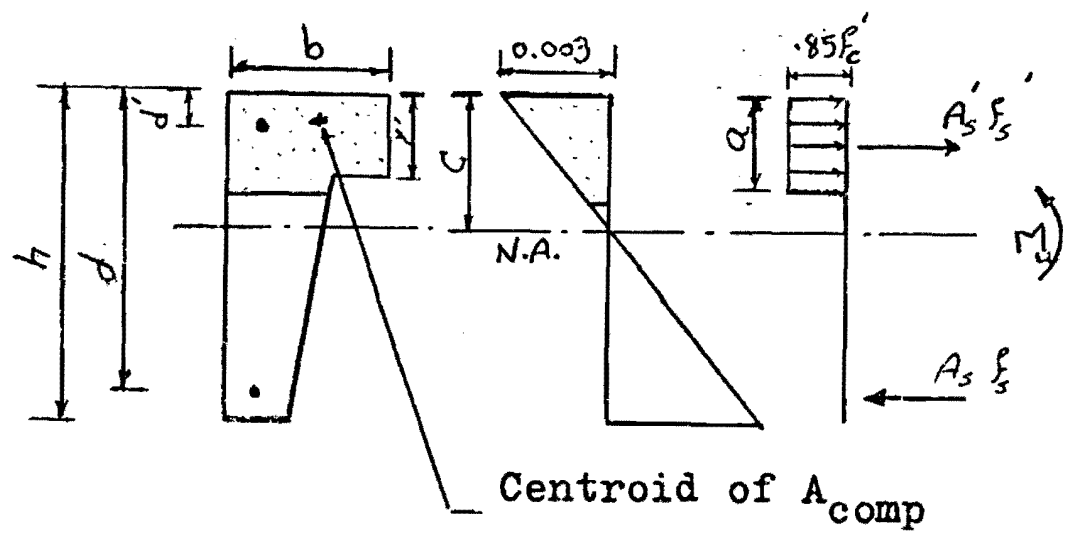

Flexure

$$
\begin{aligned}
A_{\text {comp }} & =\left(A_{s} f_{y}-A_{s^{\prime}}^{\prime} f_{s}^{\prime}\right) / 0.85 f_{c}^{\prime} \\
f_{s}^{\prime} & =E_{s}\left[\frac{0.003}{c}\left(c-d^{\prime}\right)\right] \leqslant f_{y} \\
f_{s} & =E_{s}\left[\frac{0.003}{c}(d-c)\right] \leqslant f_{y}^{\prime} \\
M_{u} & =\left(A_{c o m p}\right) 0.85 f_{c}^{\prime}\left(d-y^{\prime}\right)+A_{s}^{\prime} f_{s}^{\prime}\left(d-d^{\prime}\right)
\end{aligned}
$$

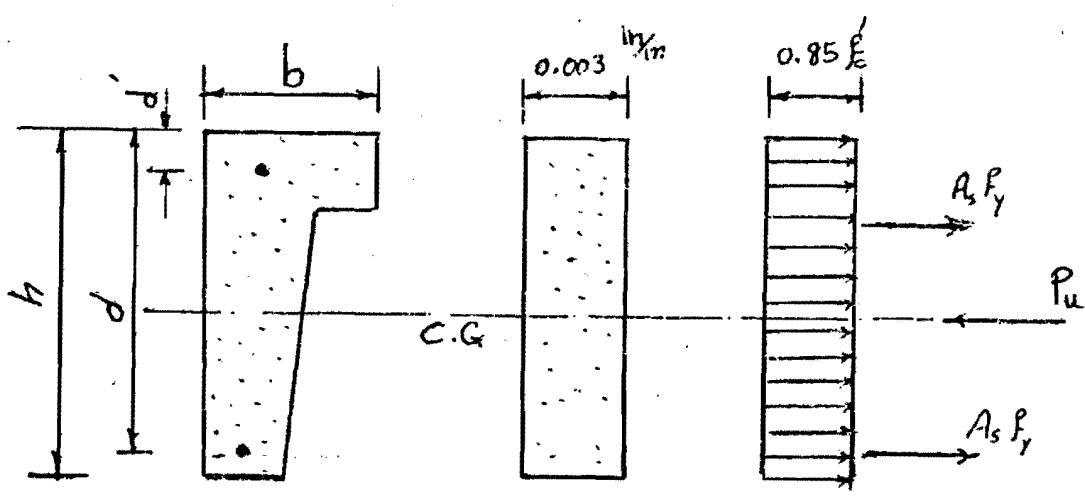

Axial

$$
\begin{aligned}
& P_{u}=0.85 f_{c}^{\prime}\left(A_{c o m p}\right)+\sum A_{s} f_{y} \\
& A_{c o m p} \simeq A_{g}
\end{aligned}
$$

Figure 3.25. Ultimate Design Relationship for Precast, Reinforced Wall Panels. (From Ref. 17) 


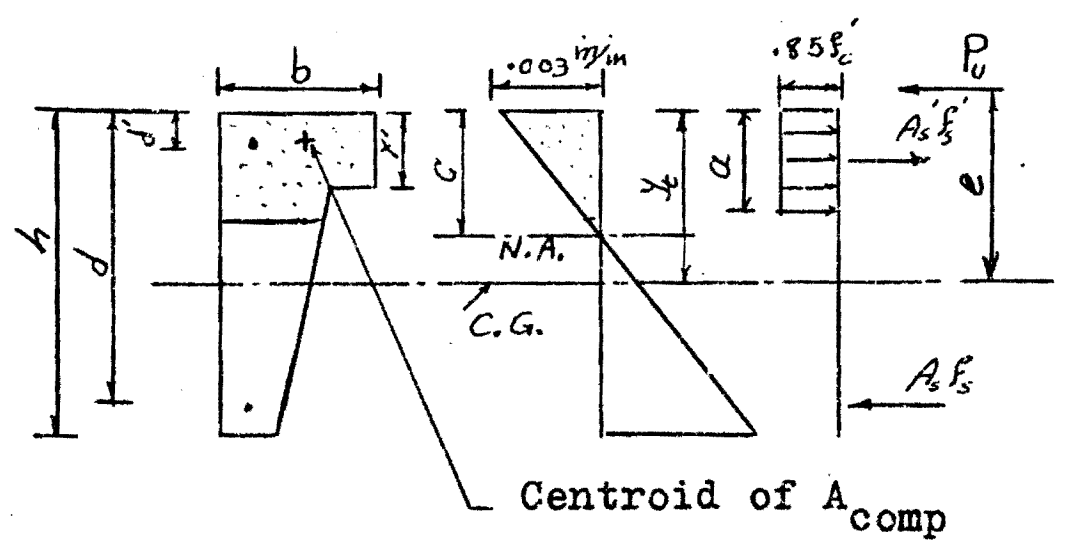

Combined Axial-Flexure, Tension Controlling

$$
\begin{aligned}
& A_{\text {comp }}=\left[P_{u}+A_{s} f_{s}-A_{s}^{\prime} f_{s}^{\prime}\right] / 0.85 f_{c}^{\prime} \\
& f_{s}^{\prime}=E_{s}\left[\frac{0.003}{C}\left(c-d^{\prime}\right)\right] f_{y} \\
& f_{s}=E_{s}\left[\frac{0.003}{C}(d-c)\right] f_{y} \\
& P_{u}=\left(A_{c o m p}\right) 0.85 f_{c}^{\prime}+A_{s}^{\prime} f_{s}^{\prime}-A_{s} f_{s} \\
& P_{u}(e) \text { about C.G. }=\left(A_{c o m p}\right)\left(y_{t}-y^{\prime}\right)\left(0.85 f_{c}^{\prime}\right)+ \\
& \quad A_{s} f_{s}\left(d-y_{t}\right)+A_{s}^{\prime} f_{s}^{\prime}\left(y_{t}-d^{\prime}\right)
\end{aligned}
$$

Figure 3.25. (Continuation), Ultimate Design Relationship for Precast, keinforced Wall Panels. (From Ref. 17) 


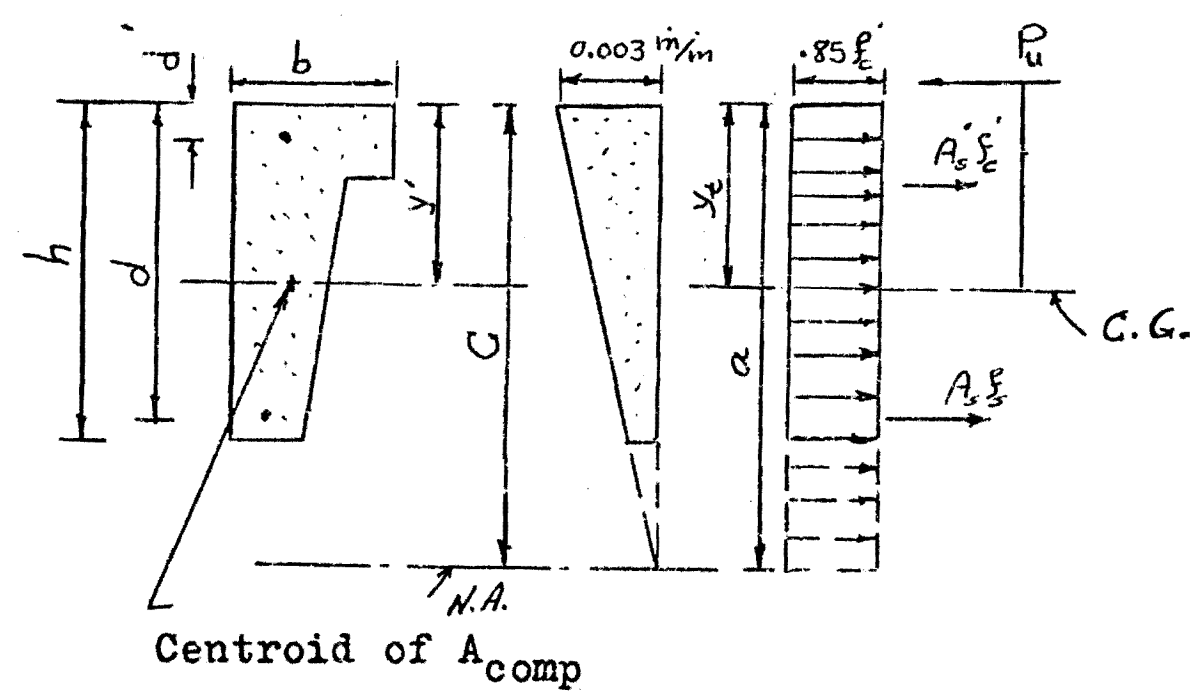

Combined Axial-Flexure, Compression Cortrolling

$$
\begin{aligned}
& A_{c o m p}\left.=A_{g}, \text { if } a\right\rangle h \\
& f_{s}^{\prime}=E_{s}\left[\frac{0.003}{c}\left(c-d^{\prime}\right)\right]\left\langle f_{y}\right. \\
& f_{s}=E_{s}\left[\frac{0.003}{c}(c-a)\right]\left\langle f_{y}^{\prime}\right. \\
& P_{u}=\left(0.85 f_{c}^{\prime} A_{g}\right)+A_{s^{\prime}}^{\prime} f_{s}^{\prime}+A_{s} f_{s}^{\prime} \\
& P_{u}(e) \text { about C.G. }=\left(0.85 f_{c}^{\prime} A_{g}\right)\left(y_{t}-y^{\prime}\right)-A_{s} f_{s}\left(d-y_{t}\right)+ \\
& \quad A_{s_{s}^{\prime}}^{\prime}\left(y_{t}-d^{\prime}\right) \\
& \text { If a }\left\langle K_{1} d, A_{c o m p}=\left[F_{u}+A_{s^{\prime}} f_{s}-A_{s^{\prime}}^{\prime} f_{s}^{\prime}\right] / 0.85 f_{c}^{\prime}\right.
\end{aligned}
$$

Figure 3.25. (Continuation). Ultimate Design Relationship for Precast, Reinforced Wall Panels. (From Ref. 17) 


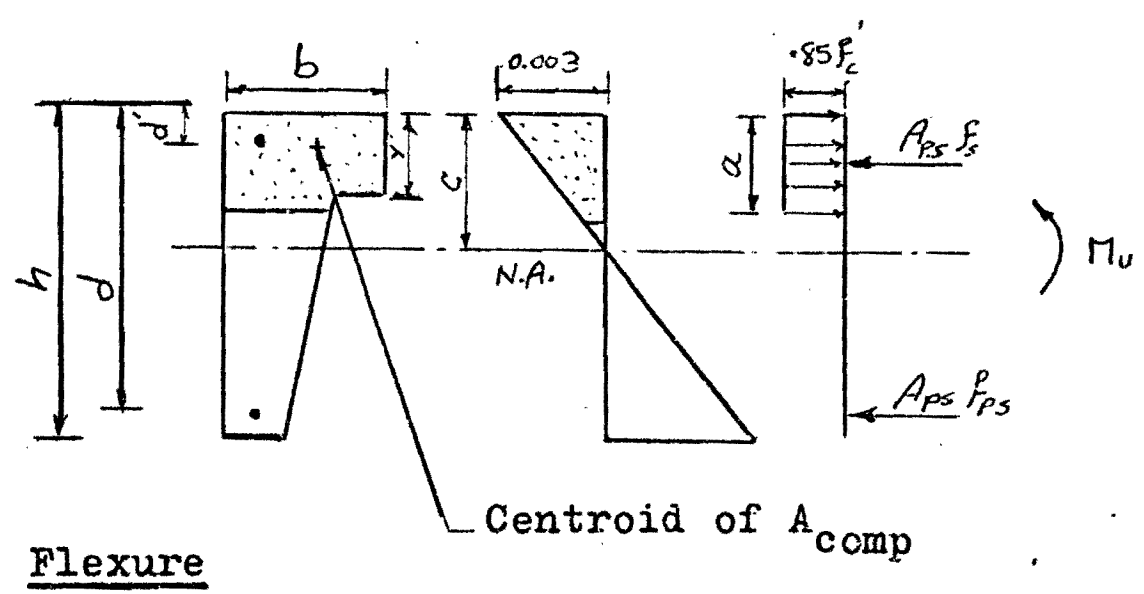

$$
\begin{aligned}
& A_{\text {comp }}=\left(A_{p s} f_{p s}+A_{p s} f_{s}\right) / 0.85 f_{c}^{\prime} \\
& \varepsilon_{s^{*}}=\left[f_{s e} / E_{s}-\frac{0.003}{c}\left(c-a^{*}\right)\right] \leqslant 0.035 \mathrm{in./in.} \\
& \varepsilon_{\mathrm{ps}}{ }^{*}=\left[f_{\mathrm{se}} / \mathrm{E}_{\mathrm{s}}+\frac{0.003}{\mathrm{c}}(\mathrm{d}-\mathrm{c})\right] \leqslant 0.035 \mathrm{in} . / \mathrm{in} \text {. } \\
& M_{u}=\left(A_{c o m p}\right) 0.85 f_{c}^{\prime}\left(\alpha-y^{\prime}\right)-A_{p s} f_{s}\left(d_{-}-d^{\prime}\right)
\end{aligned}
$$

*obtain $f_{s}$ and $f_{p s}$ from stress-strain curves.

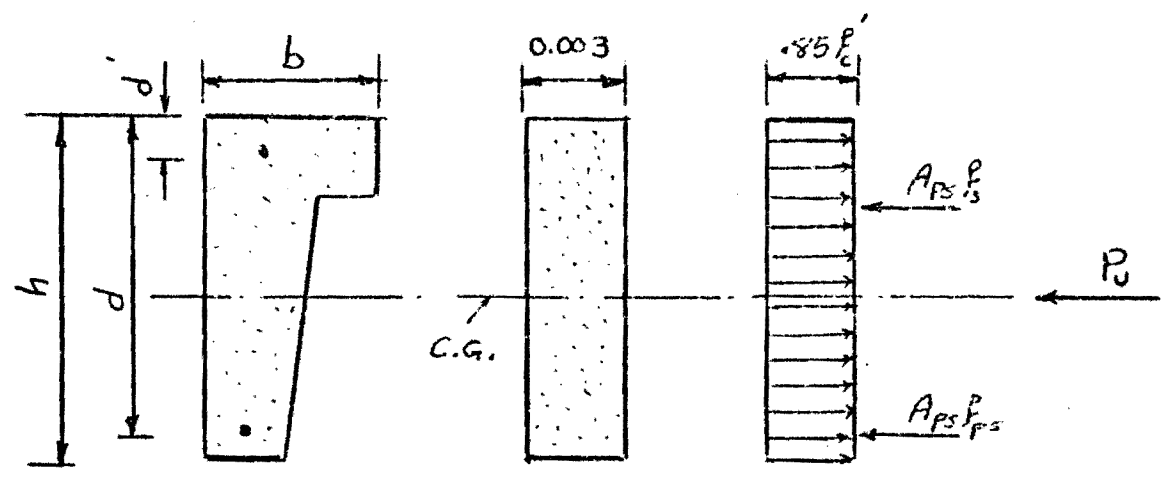

Axial

$$
\begin{aligned}
P_{u} & =0.85 f_{c}^{\prime}\left(A_{c o m p}\right)-\sum\left[A_{p s}\left(f_{s e}-0.003 E_{s}\right)\right] \\
A_{c o m p} & =A_{g}
\end{aligned}
$$

Figure 3.26. Ultimate Design Relationships for Precast, Prestressed Wall Panels. (From Ref. 17) 


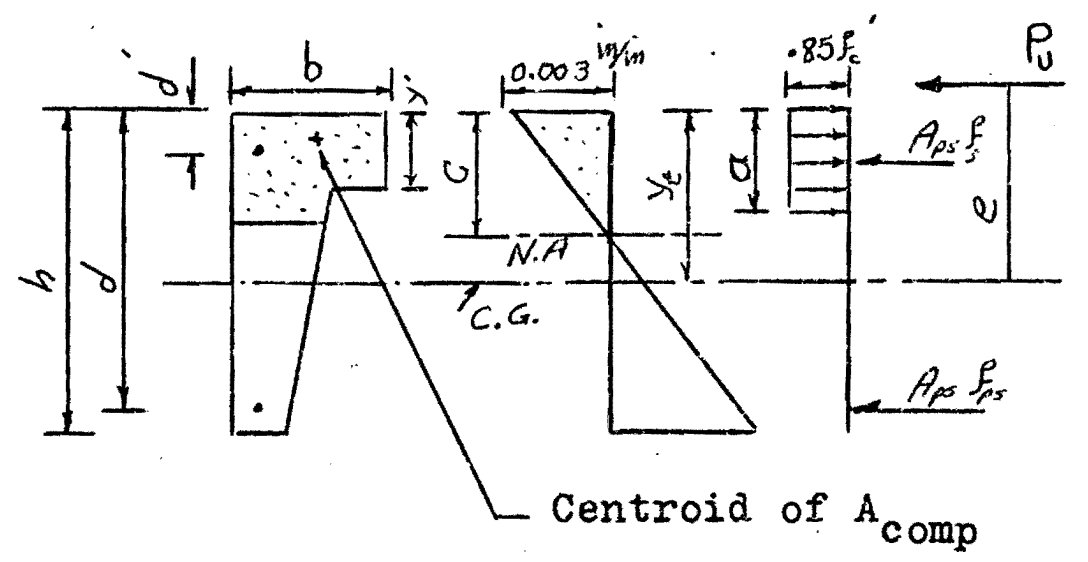

Combined Axial-Flexure, Tension Controlling

$$
\begin{aligned}
& A_{\text {comp }}=\left[P_{u}+A_{p s} f_{p s}+A_{p s} f_{s}\right] / 0.85 f_{c}^{\prime} \\
& \varepsilon_{\mathrm{s}}^{*}=\left[f_{\mathrm{se}} / \mathrm{E}_{\mathrm{s}}-\frac{0.003}{c}\left(c-d^{\prime}\right)\right] \leqslant 0.035 \mathrm{in.} / \mathrm{in} \text {. } \\
& \varepsilon_{p s}^{*}=\left[f_{s e} / s_{s}+\frac{0.003}{c}(d-c)\right] \leqslant 0.035 \mathrm{in.} / \mathrm{in} \text {. } \\
& P_{u}(e) \text { about C.G. }=\left(A_{\text {comp }}\right)\left(y_{t}-y^{\prime}\right) 0.85 f_{c}^{\prime}- \\
& A_{p s} f_{s}\left(y_{t}-d^{\prime}\right)+A_{p s} f_{p s}\left(d-y_{t}\right)
\end{aligned}
$$

* Obtain $f_{s}$ and $f_{p s}$ from stress-strain curves.

Figure 3.26. (Continuation). Ultimate Design Relationships for Precast, Prestressed Wall Panels. (From Ref. 17) 


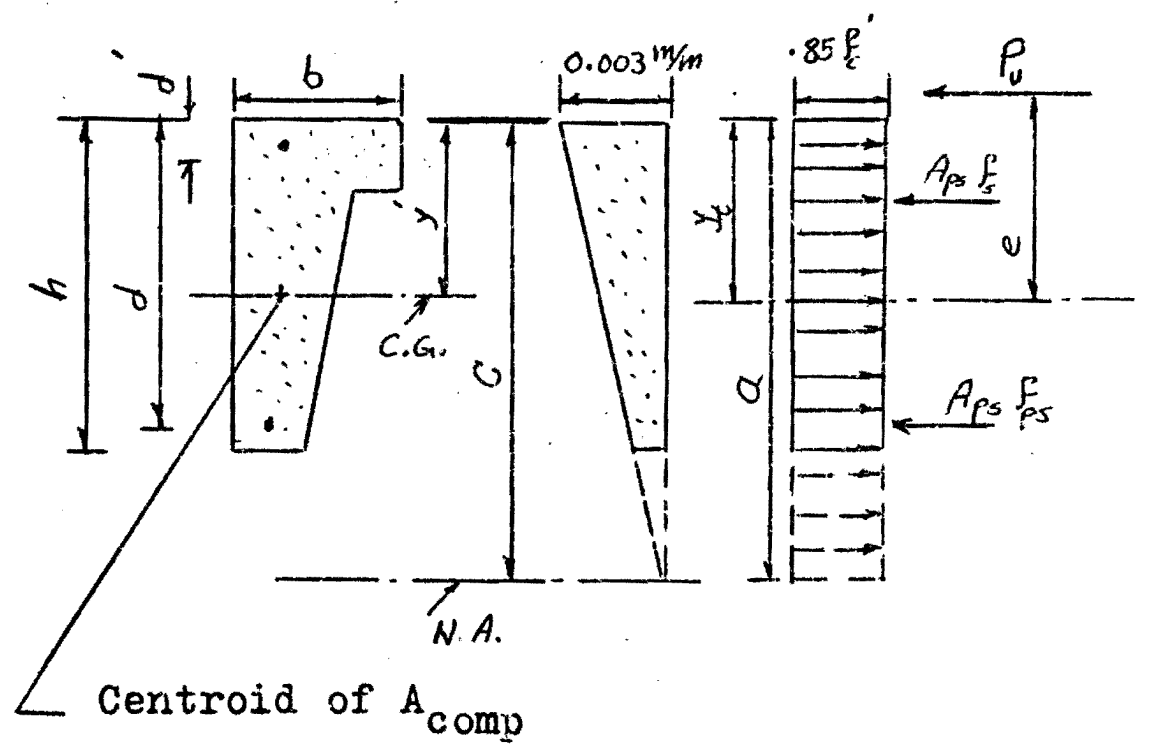

Combined Axial-Flexure, Compression Controlling

$$
\begin{aligned}
& A_{\text {comp }} \simeq A_{g} \text { if a } h \\
& \varepsilon_{s}^{*}=\left[f_{s e} / E_{s}-\frac{0.003}{c}\left(c-d^{\prime}\right)\right] \leqslant 0.035 \mathrm{in.} / \mathrm{in} \text {. } \\
& \left.\varepsilon_{p s}^{*}=f_{s e} / \varepsilon_{s}-\frac{0.003}{c}(c-d)\right] \leqslant 0.035 \text { in. } / \text { in. } \\
& P_{u}=\left(0.85 f_{c}^{\prime}\right)\left(A_{c o m p}\right)-A_{p s} f_{s}-A_{p s} f_{p s} \\
& P_{u}(e) \text { about C.G. }=\left(A_{c o m p}\right)\left(y_{t}-y^{\prime}\right)-A_{p s} f_{s}\left(y_{t}-d^{\prime}\right)+ \\
& A_{p s} f_{p s}\left(d-y_{t}\right) \\
& \text { If } a\left\langle h, A_{c o m p}=\left[P_{u}+A_{p s} f_{p s}+A_{p s} f_{s}\right] / 0.85 f_{c}^{\prime}\right.
\end{aligned}
$$

Figure 3.26. (Continuation). Ultimate Design Relationships for Precast, Prestressed Wall Panels. (From Ref. 17) 
ture strain is known, the maximum strand strain at ultimate should not exceed $3.5 \%{ }^{17}$

Slenderness effects should be considered when designing load bearing panels, and also be a consideration in tall, slender curtain wall panels. ${ }^{17}$

In order to control cracking, the modulus of mupture of the concrete should not be exceeded under service loads. ACI 318-71 Code $^{2}$ specifies the modulus of rupture of concrete as $f_{r}=7.5 f_{c}^{\prime}$ for nomal weight concrete. The value of $f_{r}$ is to be multiplied by 0.75 for "ail light weight", and 0.85 for "sand light weight" concrete. 17

To be reasonably assured of "crack-free" sections, a factor of safety should be used in the design as 1.65 for normal weight concrete and 2.0 for sand light weight concrete. $^{17}$ 


\subsection{CONNECTIONS}

\subsubsection{General}

The use of joints and connections for the transmission of shears, axial loads, moments and torques from member to member, and from menber to sub-structure is the most significant factor in precast concrete construction. General guidelines for the design of connections to assure satisfactory service behavior and maximum economy are as follows: 17

1) Connections are to be located where concentration of stresses exist. All possible loadings and movements at the connection should be accounter. for in the design.

2) Since tolerance of fabricating connection and of members framing into a connection cause variation in the location of force acting at the connection, it should be designed to withstand forces acting anywhere within the tolerance area.

3) Connection economics are achieved through repetitious use of details. For similar types of connections, the details should be identical wherever possible.

Loading conditions to be considered in the design of joints and connections are service loads including wind and earthquake forces, volume changes due to shrinkage, creep, temperature changes, erection. loads and loading encountered in stripping forms, shoring and removal of shores, storage and transportation of members. 1 The ultimate strength design method could most adequately be used, with the applic- 
able load factors specified in the ACI 318-71 Code. ${ }^{2}$ In cases where small deviation from design dimensions due to fabrication or construction tolerances can have significant effect on the design (such as clip angles, corbels, etc.), or where loads in excess of those anticipated can occur, an additional load factor of $4 / 3$ j.s recommended. 17

According to ACI 318-71, section $9 / 3 / 7$, forces resulting from creep, shrinkage and temperature change may be treated as dead load. Prestressed Concrete Institute ${ }^{17}$ recommends that a minimum load factor of 1.6 (this is the average of dead and live load factors for structures with normal ratio of dead to live loads) be used for forces resulting from volume change movements.

\subsubsection{Design}

A. Transfer of Shear. The first capability of a connection should be to transfer the shear forces. The transfer of shear may be accomplished by using reinforcing steel extended as dowels coupled with cast-in-place concrete placed between roughened concrete interfaces. Mechanical devices such as embedded plates or shapes, brackets, prestressing force applied across the connecting surfaces, or any other way which meets all accepted unit stress requirements for the materials involved, and meets the ultimate strength requirement specified by ACI $318-71^{2}$ may also be used.

In case of simple reinforcing dowels, the extension 
of reinforcing bars in a flexural member or the placement of dowels anchored in each connecting member, either by mechanical anchorage devices or with minimum embedment required to develop the full yield strength of the bar through bond may be used to transfer shear (see Fig. 3.27). ${ }^{1}$ The allowable shear, based on extended bars or dowels, should not exceed $v_{u}=\sqrt{\left(A_{s} f_{s}\right)^{2}+\left(1.5 D^{2} f_{c}^{\prime} \operatorname{Sin} \theta\right)^{2}}$, where $v_{u}$ is the total vertical shear, and $f_{S}$ is the allowable stress in bars or dowels. The second term in the above equation should not be considered if the concrete cover on the dowel is less than 3 -in. ${ }^{1}$

Brackets and corbels are protmusions cast onto the side of a column or wall to serve as a beam seat. Brackets shown in Fig. 3.28 can be aesigned based on the following equation: ${ }^{17}$

$$
\begin{aligned}
& v_{u}=\phi b d \sqrt{f_{c}^{\prime}} c_{1} c_{2}, \text { where } \phi=0.85 \\
& c_{1}=6.5\left(1-0.5^{\left.d / I_{v}\right)}\right. \\
& c_{2}=\frac{\left(1000 / \rho_{v f}\right)^{\left(1 / 3+0.4 T_{u} / v_{u}\right)}}{10}, \text { where } \rho_{v f}=\frac{A_{v f}}{b d}
\end{aligned}
$$

The magnitude of $\mathrm{T}_{u}$ can be determined by analysis, but it is required that a value not less than $0.2 \mathrm{v}_{u}$ be used (see Fig. 2.5, where this horizontal force is denoted by $N_{u}$ ). The main tensile reinforcement, $A_{v f}$, should be anchored positively near the extreme outer face by welded cross bars or by welding to confinement angles (see Fig. 3.29). Horizontal bars, $A_{v h}$, equal to $A_{v f} / 2$ should be placed in the 


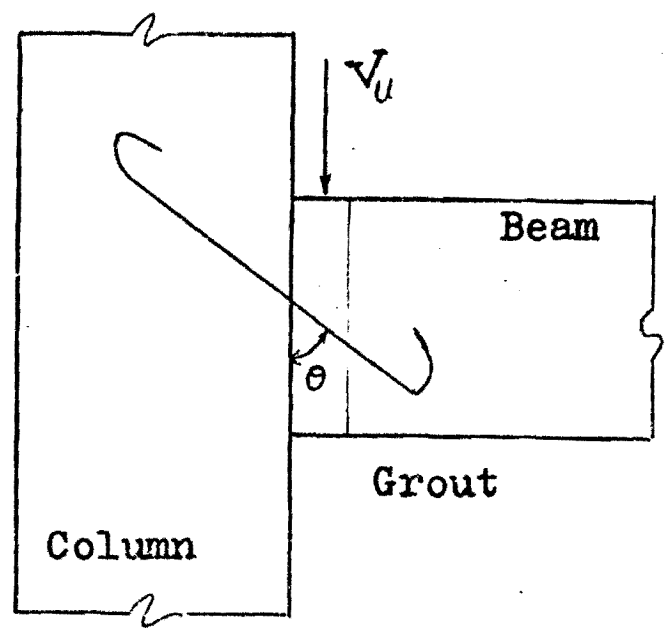

Either member is precast.

Figure 3.27. Reinforced Dowels. (From Ref. 1)

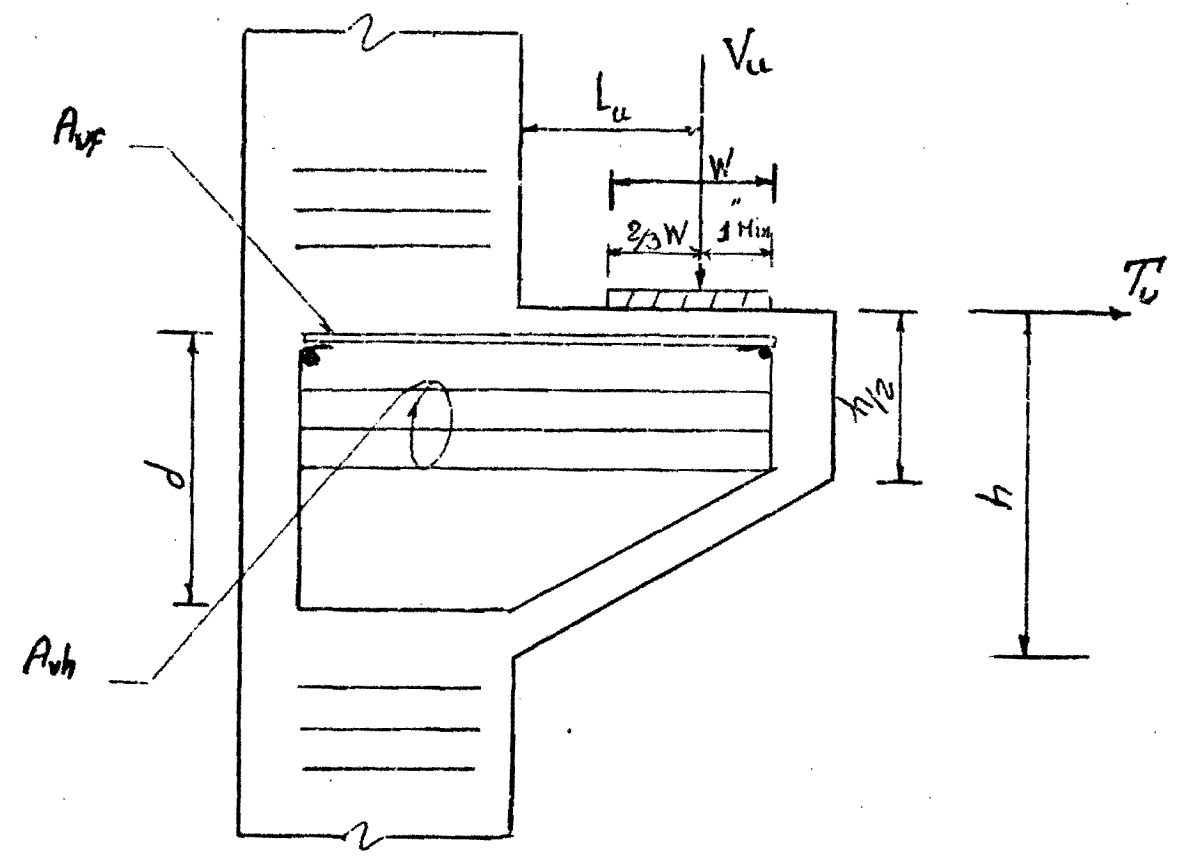

Figure 3.28. Concrete Bracket. (From Ref. 17) 
upper two-thirds of the haunch, where $A_{v f}=\frac{V_{u}}{\phi f_{y} \mu}$. The position of the applied vertical load is assumed to be located at the outer third point of the bearing contact area. The ultimate bearing stress without confinement angles should not exceed $0.5 f_{c}^{\prime}$, as suggested by PCI. ${ }^{17}$

Brackets may be made by fastening steel clip angles or other steel shapes to plates which are cast flush with the vertical faces of concrete members (see Fig. 3.30). This type of bracket also shouid be designed to resist all shears and moments developed by the connection. Structural steel shapes or plates may also be used in transferring shear (see Fig. 3.31).

Another method of transferring shear is by welded headed studs (Fig. 3.32). The full pull-out capacity given by $\mathrm{PCI}^{17}$ for welded headed studs is the lesser of $P_{u}^{\prime}=\phi 16\left(I_{e}+d_{h}\right) \sqrt{f_{c}^{\prime}} I_{e}$ or $P_{u}^{\prime}=09 A_{s o} f_{s}^{\prime}$, where $\phi=0.85$, and $A_{\text {So }}$ is the shank area of the stud, and $\hat{r}_{S}^{\prime}$ is the ultimate tensile strength of stud steel. 17

Metal studs also can be used by welding to bracket plates or similar pieces (Fig. 3.33), for shear transfer and anchorages. The allowable shear may be determined by the following expression given by the ACI Committee $512:^{1}$ $v_{u}=110 d^{2} \sqrt{f_{c}^{\prime}}$, where $h / d$ is equal to or greater than 4.2 , and $v_{u}=27 h d \sqrt{f_{c}^{\prime}}$, where $h / d$ is iess than 4.2 .

B. Transfer of Moment. The transfer of moment through connections between precast members or cast-in-place 

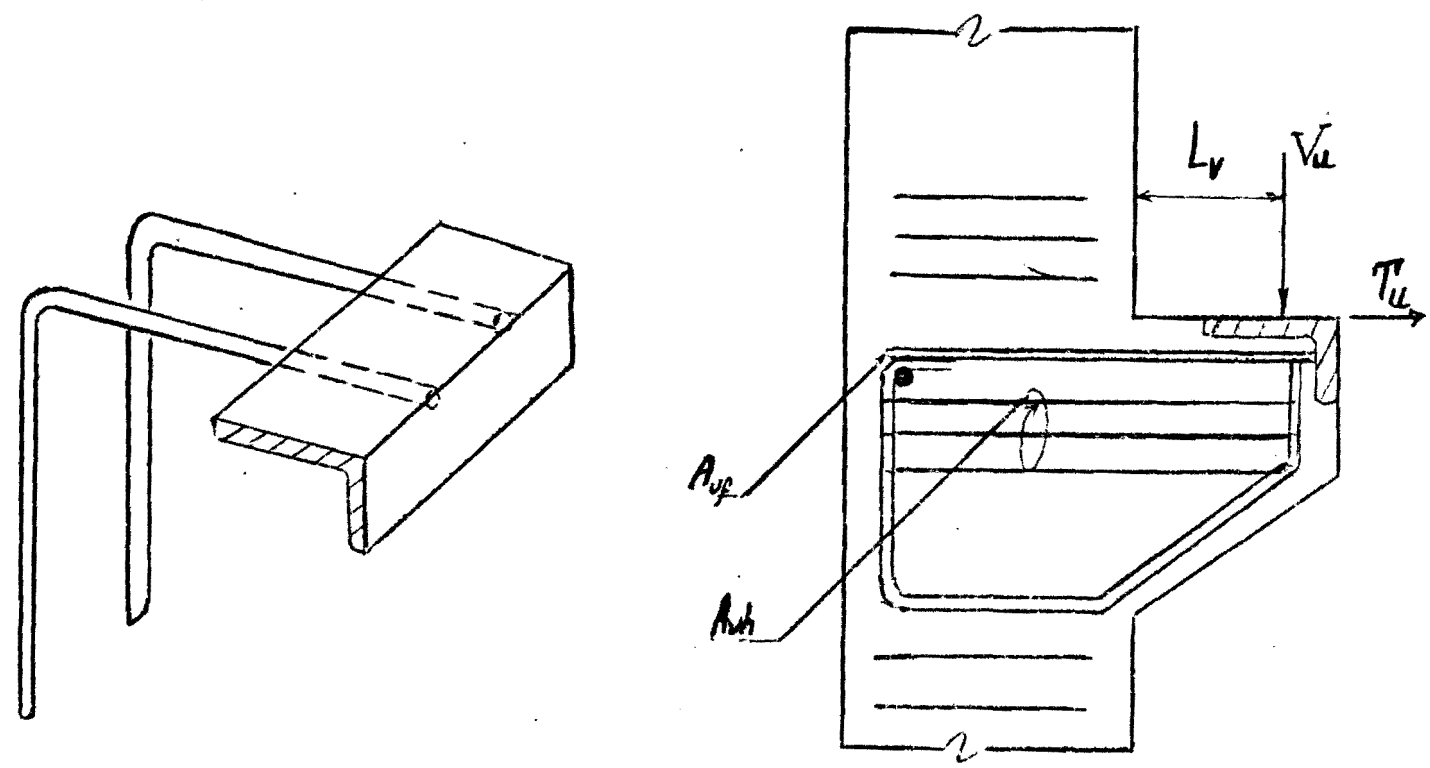

Figure 3.29. Confinement Angle Used in Bracket. TFrom Ref. i7)

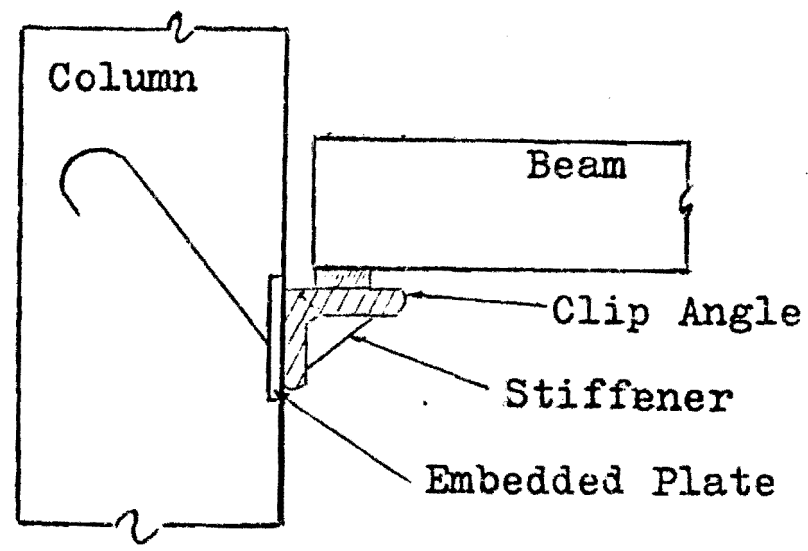

Figure 3.30. Steel Bracket in Beam-Column Connection. (From Ref. 1) 


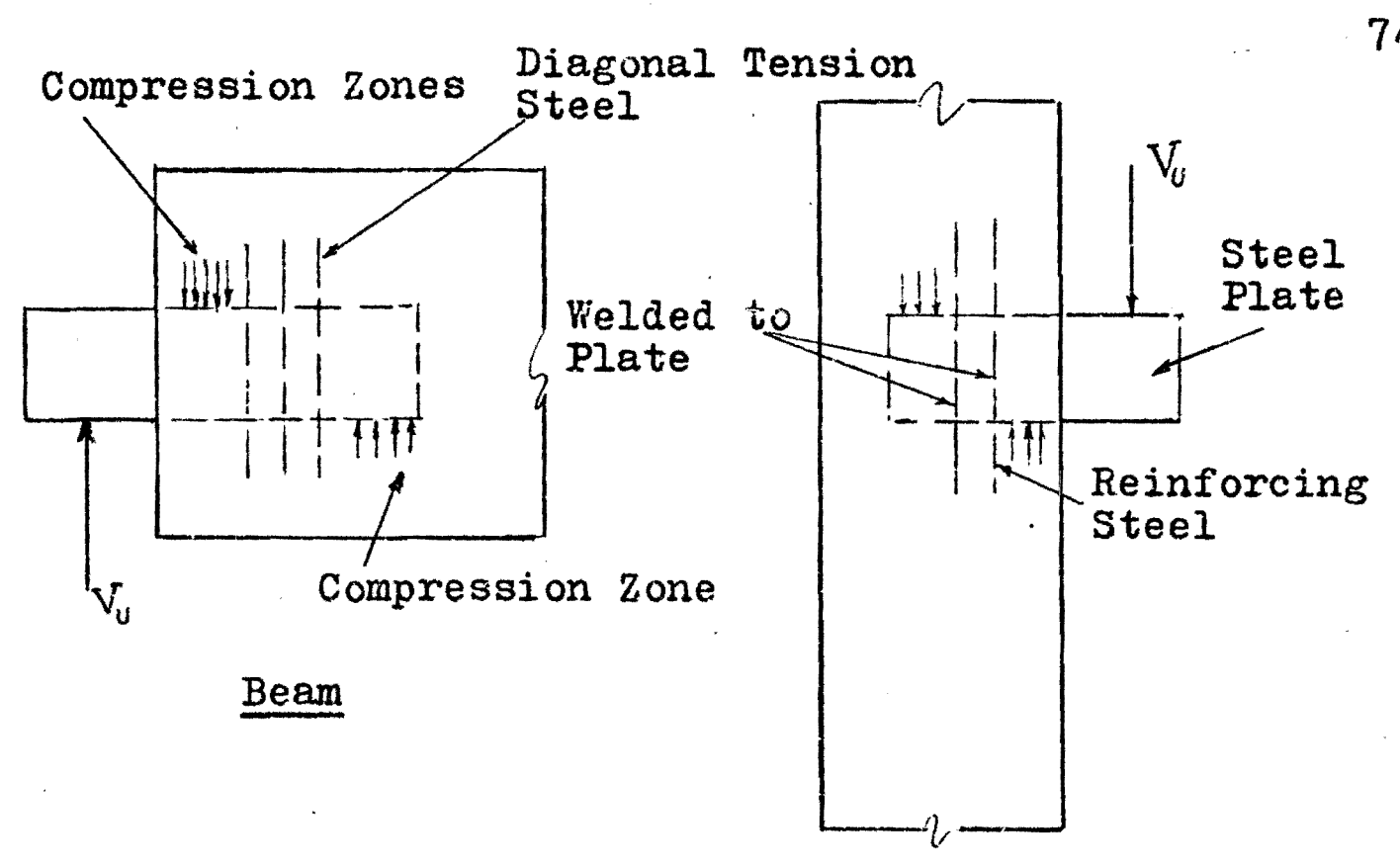

Column

Figure 3.31. Shear Transfer Devices for Beams and Columns. (From Ref. 1)

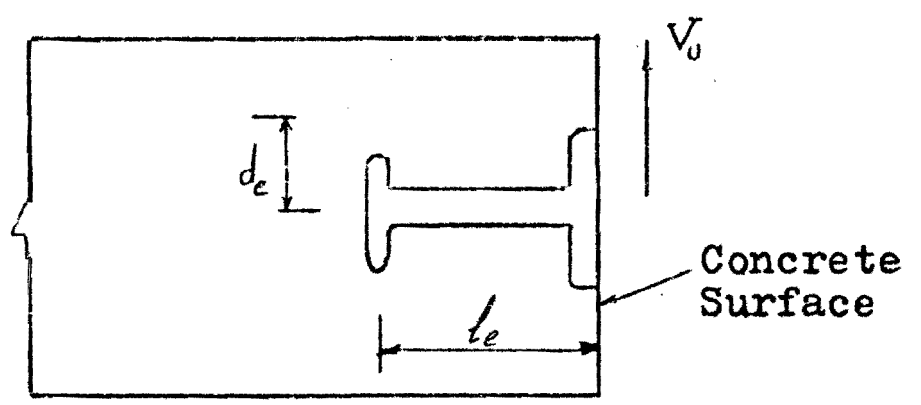

Figure 3.32. Shear Loading on Stud Near a Free Edge. (From Ref. 17) 


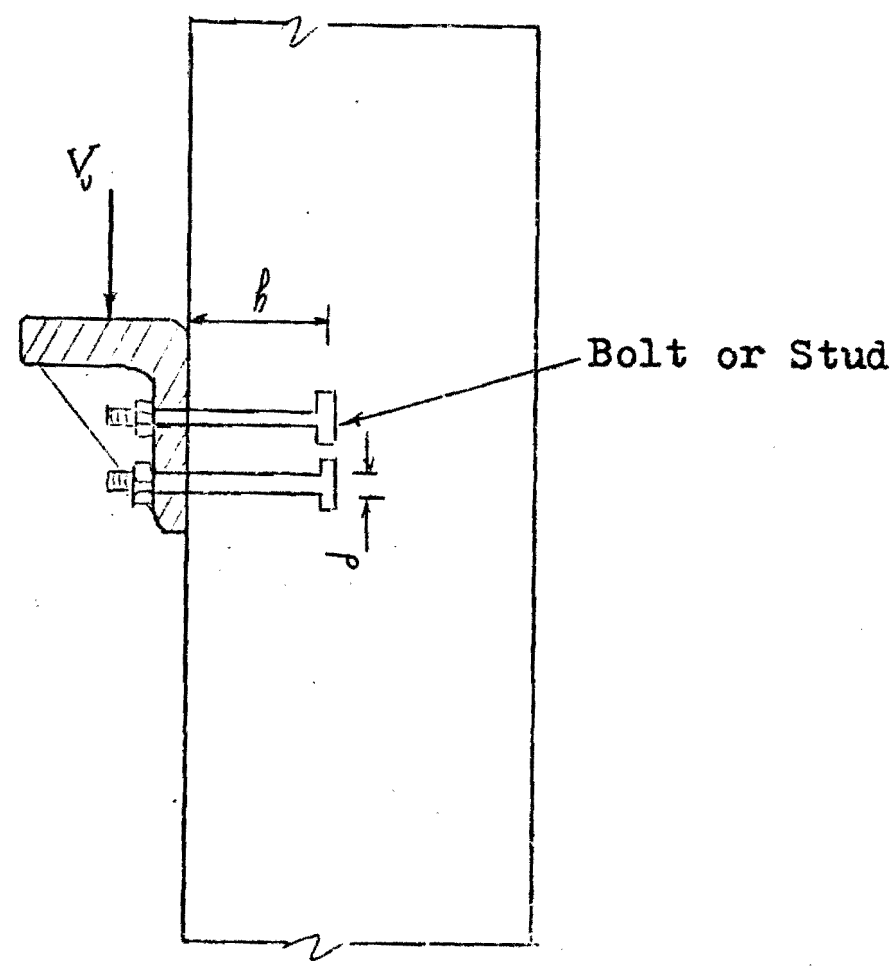

Figure 3.33. Bolt or Stud for Shear mransfer and Anchorage. (From Ref. 1) 
members (foundation) may be accomplished by: reinforcing steel extended as dowels; or prestressing force applied to the joint and properly developed by the connecting members. 1 Reinforcing bars which are lapped or welded, or steel plates or shapes which are welded to reinforcing bars, or to other steel plates or shapes should be detailed so that there is a minimum eccentricity of force transferred through the connection.

The design of the connection and the adjacent members should consider all stresses due to eccentric loading conditions, creep, shrinkage and temperature changes. Also, the design of connections should always include an investigation of the possibility of torsional stresses due to unequal loading, wind and seismic forces, differential settlement or temporary erection loading conditions. In general, members should be detailed so that torsion is held to a minimum at the connection.

c. Transfer of Axial Tension and Compression. Axial tension forces carried through a connection should not produce stresses in any part of the connection which combines with bending stresses or torsional stresses that exceed permissible stresses for the materials involved. Structural steel shapes may be used to transfer axial tension in connections provided that the total stress in each precast element is transferred by bond producing devices fixed to the structural steel shape so embedded. ${ }^{1}$ 
Compression also should be transferred across a connection without eccentricity whenever possible. The stresses resulting from axial compression combined with any other stresses on the section should be kept within the allowable stresses for the materials involved. Structural steel shapes may be used just as mentioned for tension stresses. 1

\subsubsection{Connection Details}

A. Column to Foundation. Due to the importance of transferring the loads from columns to the foundation, special attention should be made in designing the column to foundation connections. One standard method is shown in detail ir Fig. 3.34. In this method, the dowels are set by template, with sleeves to allow some later adjustment. The bearing plate is set level and to accurate elevation on a grout pad. The column j.s lowered onto the plate and guyed or braced, thus freeing the crane quickly for other operations. The dowels are then welded to the embedded angles. This detail provides full strength, continuity, and gives the flush appearance of monolithic concrete. 7

Another detail, as shown in Fig. 3.35 , is suggested by PCI. 17 In this detail, the precast concrete column is placed on the cast-in-place base and anchor bolts from the base are bolted to the column to create enough strength and continuity. The base plate is used in order to distribute load on the footing. 


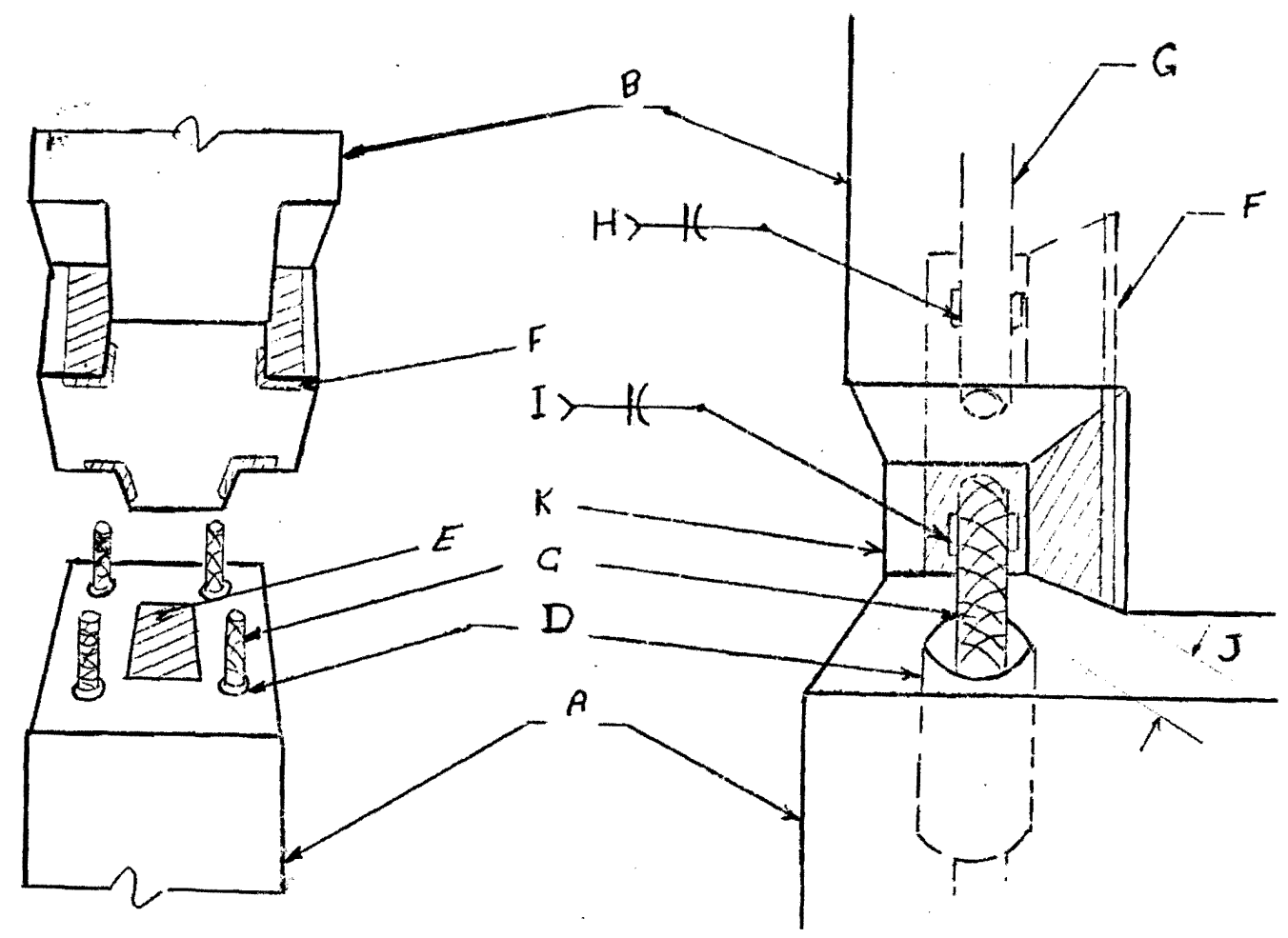
$A=$ Cast-In-Place Footing
$G=$ Column Rebar
$B=$ Precast Column
$\mathrm{C}=$ Dowels
$D=$ Sleeves
$E=$ Bearing Plate
$F=$ Embedded Angle
$\mathrm{H}=$ Shop Weld
$I=$ Field Weld
$J=G a p$
$\mathrm{K}=$ Corner Block-Out

Figure 3.34. Column to Footing Connection. (From 


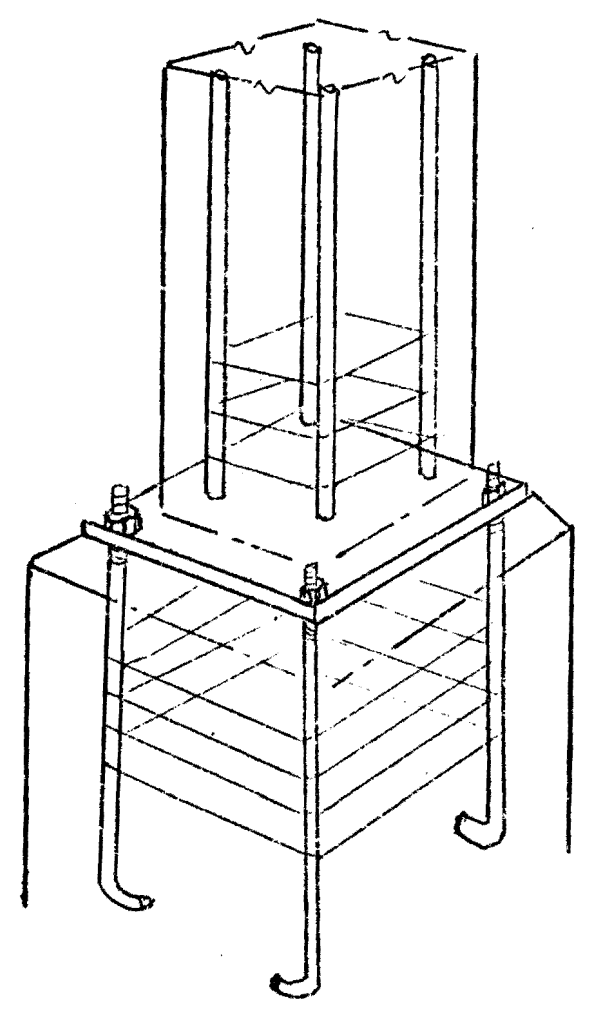

Figure 3.35. Column Base Connections. (From 
Another method of connecting the columns or walls to the foundation is by post-tensioning, as shown in Fig. 3.36. 21 The tying technique begins with the pouring of the foundation bars attached to threaded anchor plates at the bottom ends which are cast into the concrete. These foundation bars are greased and paper wrapped to insure elongation during tensioning.

Additional bars are then connected to the foundation tendons through couplers at the first floor level, ready to receive the wall panels. All bars are previously cut to the proper floor height, which simplifies handling. Being rigid, these bars stand vertical on their coupler connections without support.

Wall panels are next lowered over the bars through preformed holes. When the walls are in position, anchor plate and nut assemblies are placed over the bars. Hydraulic jacks are then attached and the bars stressed. When the specified tension is reached, the nuts are turmed down to their final position against the face of the anchor plates. Grouting is done at each level immediately after tensioning.

B. Column to Column. Due to the similarity between connection of column to column and column to foundation, similar detailing can be used as presented in section 3.3.3. A. In addition to connection details mentioned, Fig. 3.37 shows a detail of wall-to-wall connections using friction 


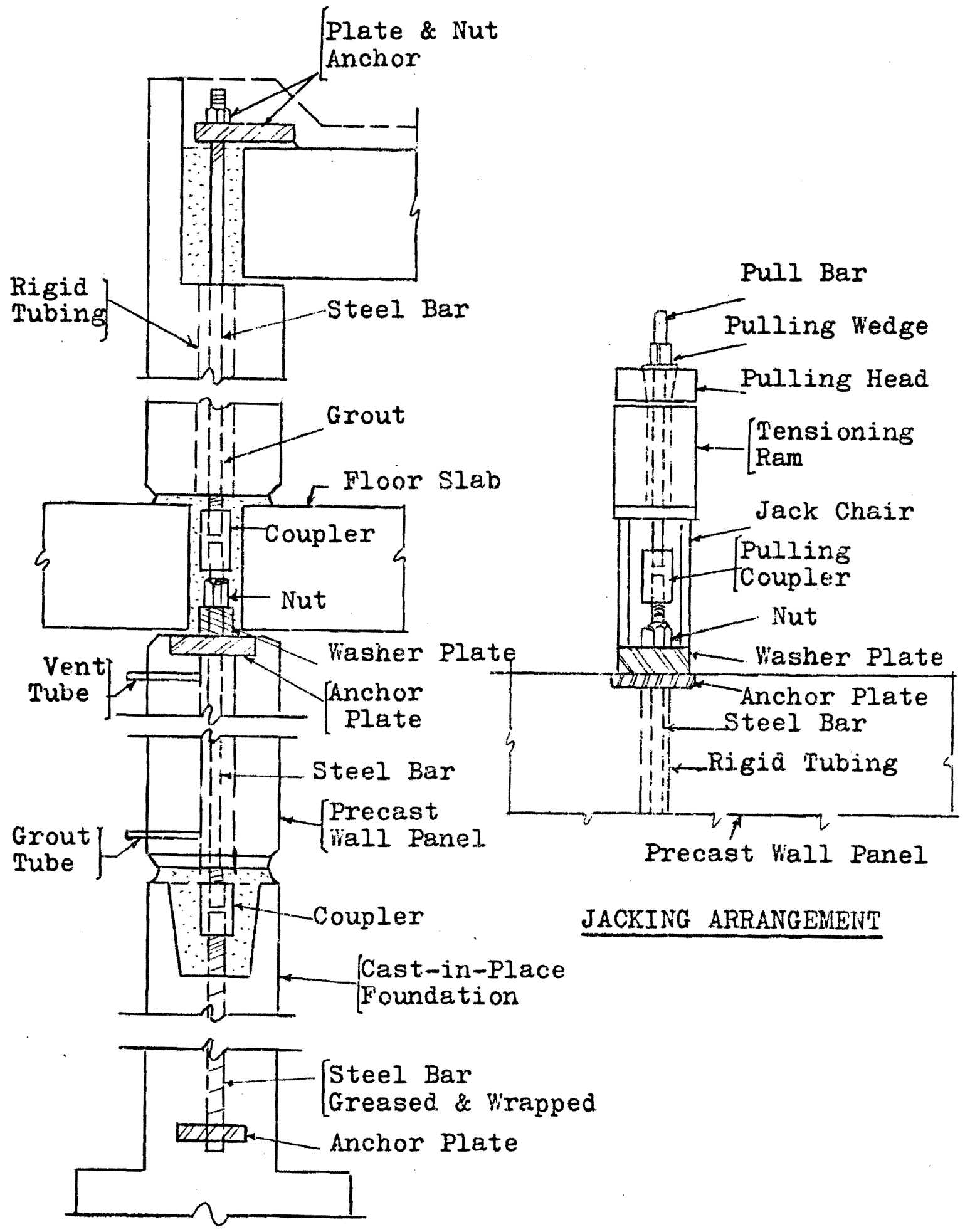

Figure 3.36. Typical Assembly of Post-Tensioning 


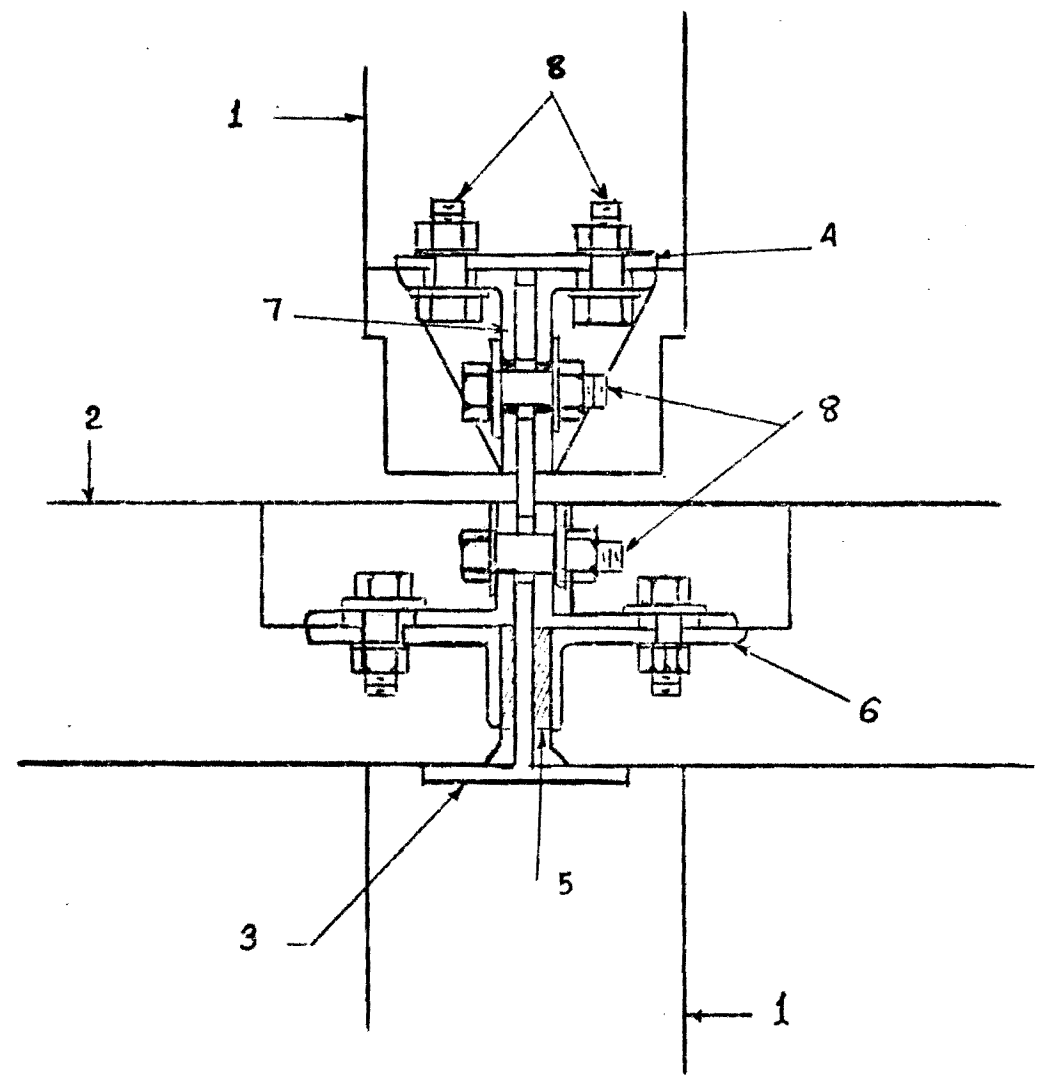

1. Bearing Wall Panel

2. Floor Panel

3. Wall Insert-Top

4. Wall Insert-Bottom

5. Metal Shims
6. Floor Insert

7. Connection Miake-Up Pieces

8. Friction Bolted Connection

Figure 3.37. Wall-To-Wall Connection. (From Ref. 20) 
bolts. 20

c. Beam to Column. Structural continuity and ease of erection comprise the two chief conflicting requirements of beam to column connections.

One type of connection is the knife connection (Fig. 3.38), which provides full continuity for superimposed dead and live load negative moment. 7 Several tests for widely varying application have shown very satisfactory behavior at working load. 7

Another method of connecting beam to column or wall is by a connection which is composed of steel inserts embedded in the concrete panels (Fig. 3.39). These are held in place by steel welded anchor bars which are used to develop the required strength by friction shear. During erection, when two such inserts are placed adjacent to each other, a third element (a steel make-up piece) is friction bolted onto the embedded inserts, thus completing the connection. The makeup pieces are preslotted to take up manufacturing and erection tolerances. 20 More details of beam to column or wall connection are shown in Fig. 3.40.

D. Beam to Beam. Beam to beam and column to beam connections are similar and the same general discussions of the details apply. Some of the typical details of connection of beam to beam are shown in Figs. 3.41 through 3.43 . E. Slab to Beam or to Slab. Some of the typical details of siab to beam or to slab connections are shown in Figs. 3.44 through 3.48 . 


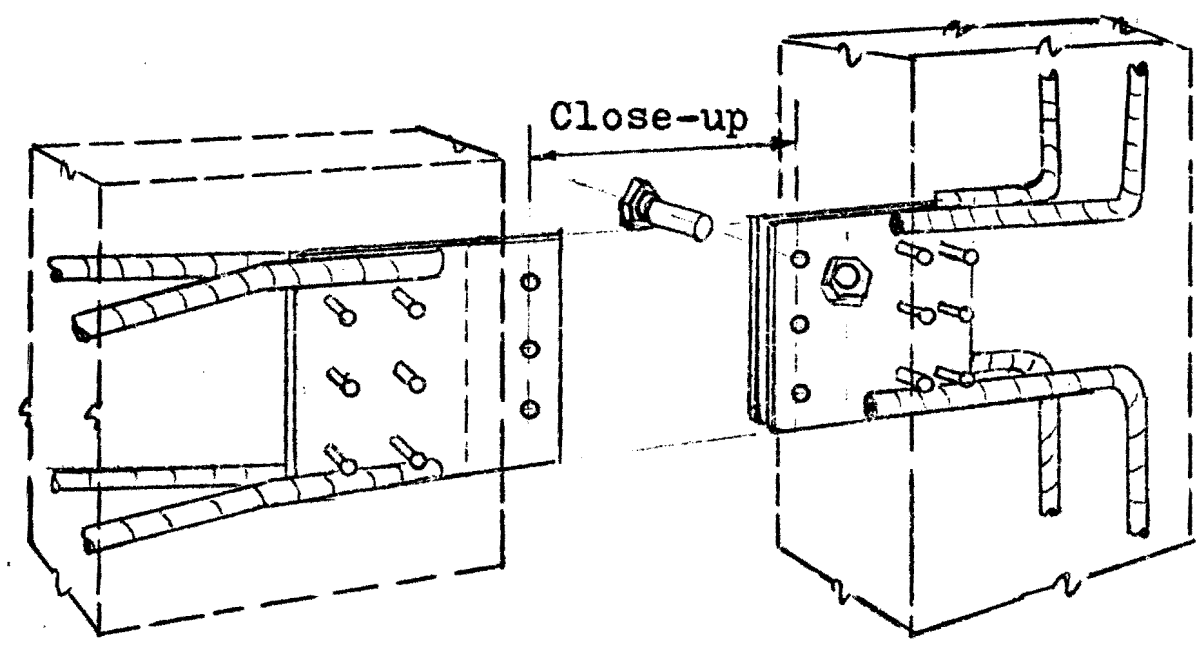

Beam

Column

Figure 3.38. Knife Connection for Beam to Column. (From Ref. 7) 


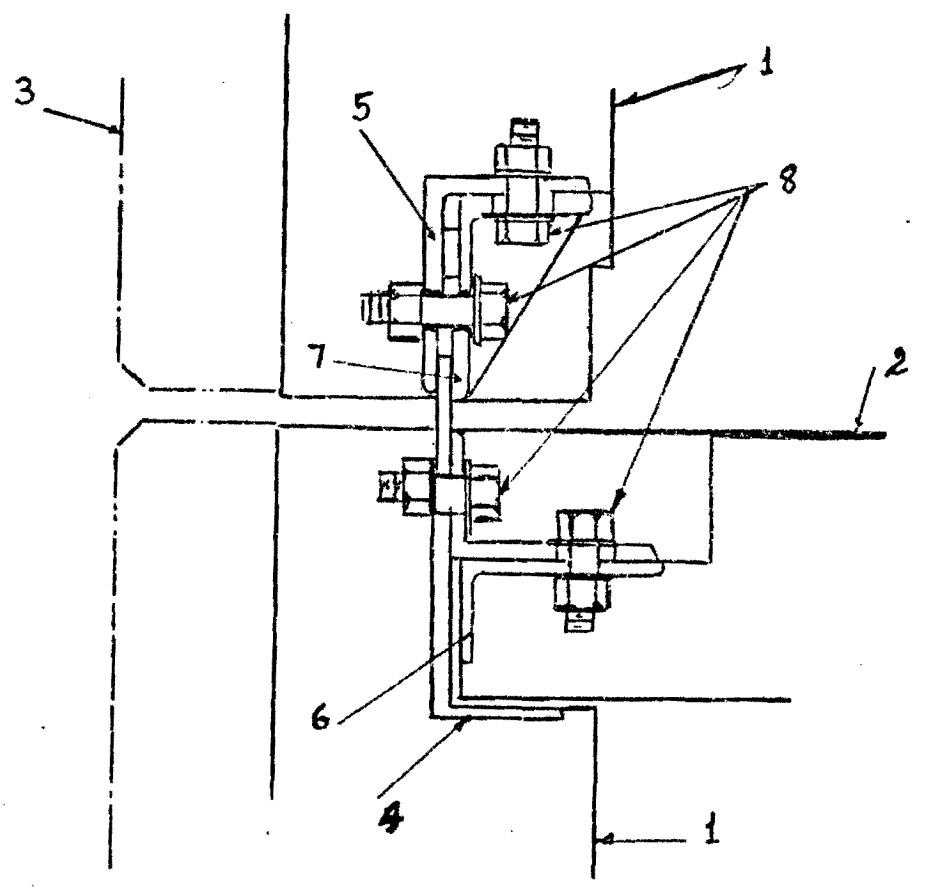

1. Exterior Bearing Viall Fanel

2. Floor Panel

3. Cladding

4. Wall Top Insert

5: Wald Bottom Insert
6. Floor Insert

7. Connection Make-Up Pieces

8. Friction Bolted Connections

Figure 3.39. Exterior Wall-to-Floor-to-Wall Connection. (From Ref. 20) 


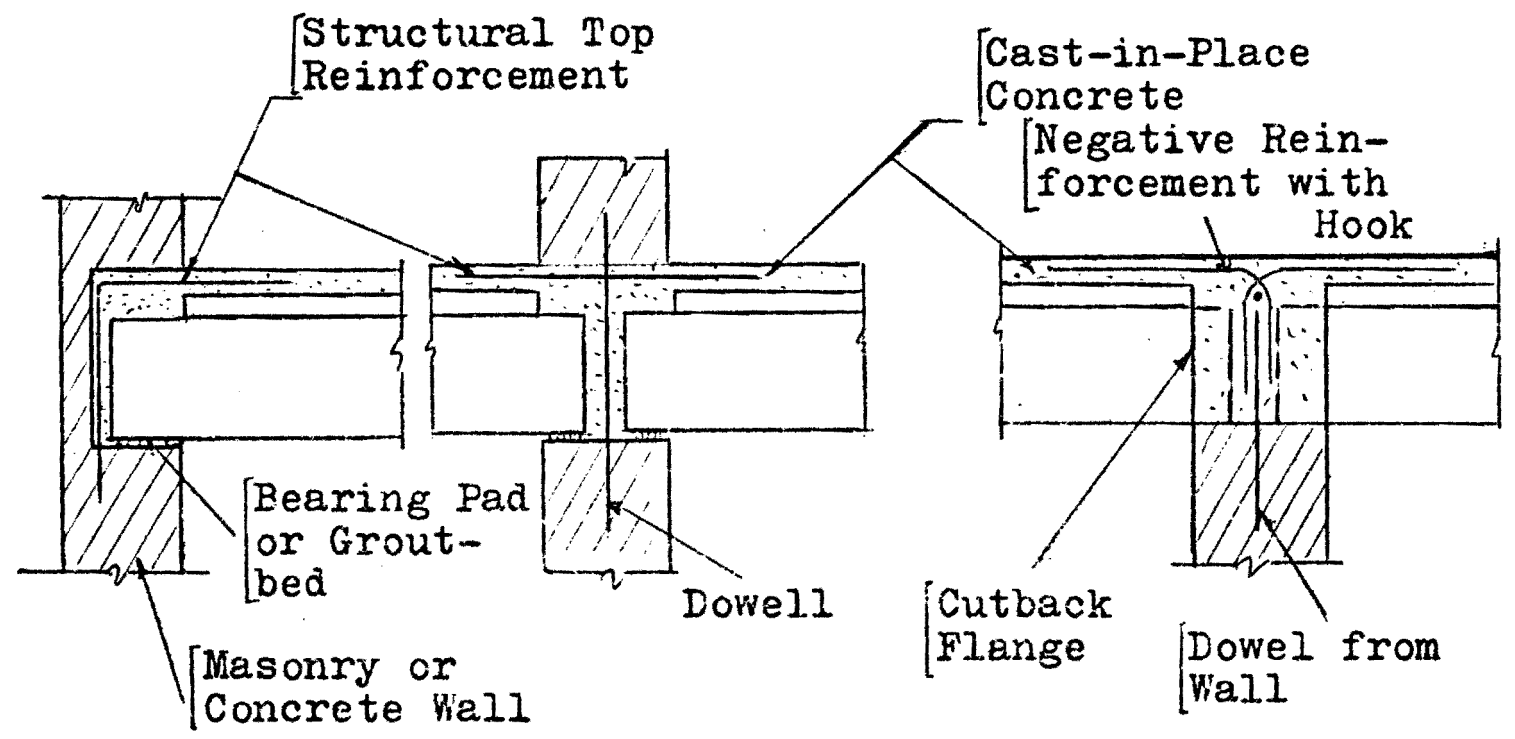

Figure 3.40. Connection Details of Beam to Wall. (From Ref. 13)

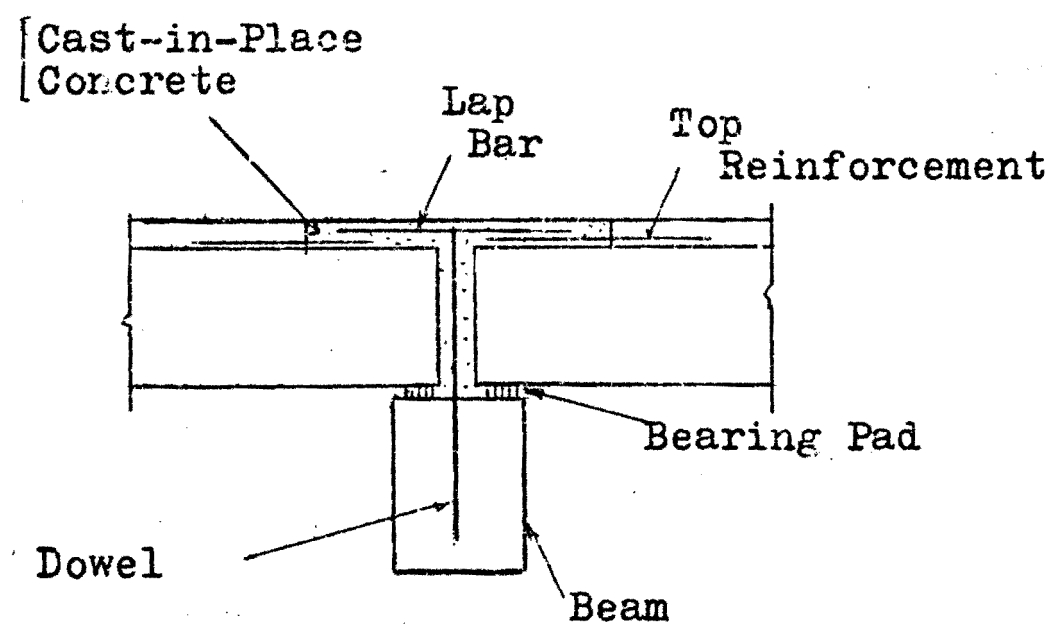

Figure 3.41. Connection Detail of Beam to Beam. (From Ref. 13) 
Seat Angle and Plate Insert

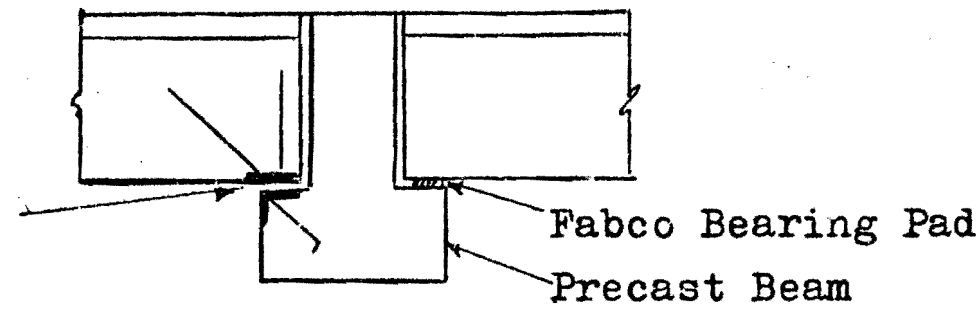

Figure 3.42. Connection Detail of Beam to Beam. (From Ref. 13)

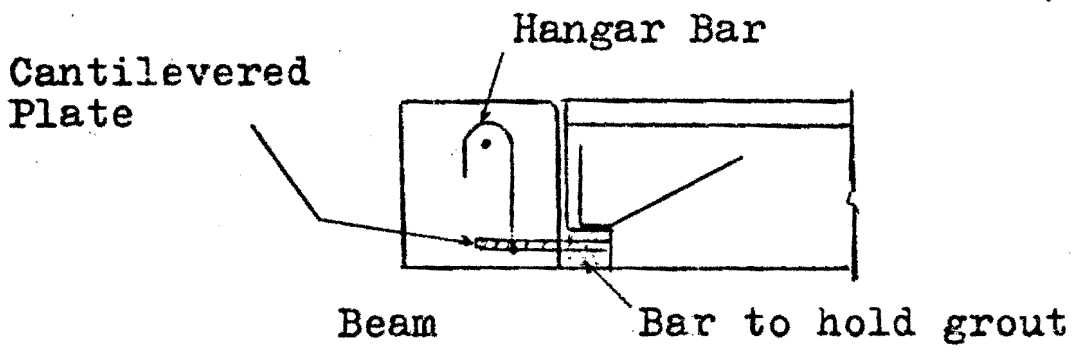

Figure 3.43. Cornection Detail of Beam to Beam. (From Ref. 13)

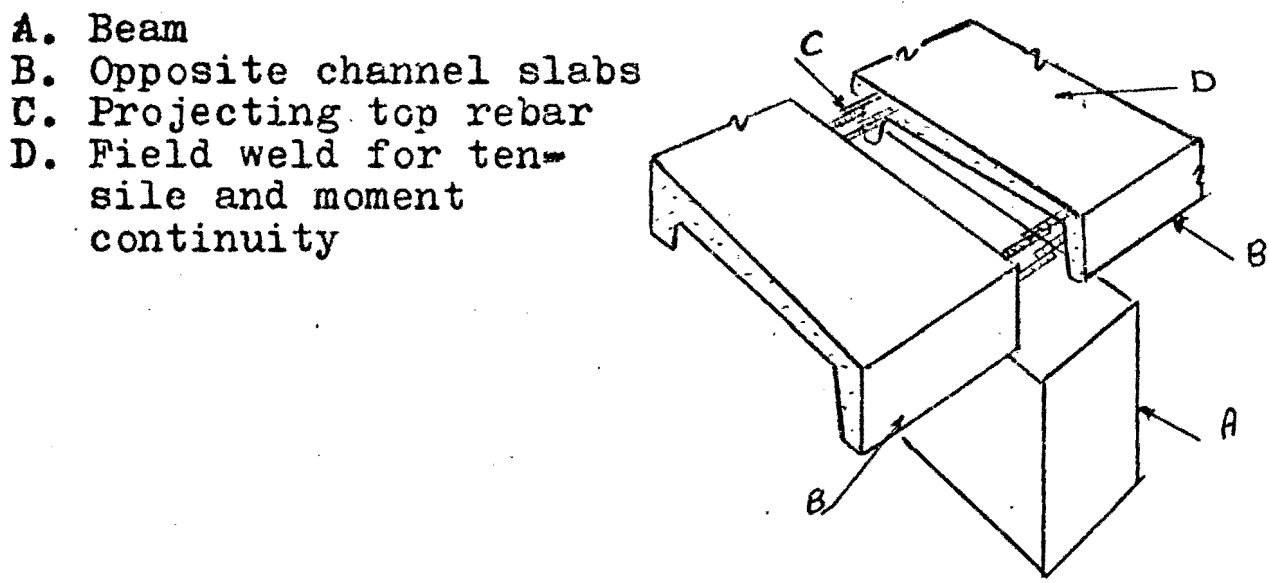

Figure 3.44. Connection Detail of Slab to Slab. (From Ref.7) 


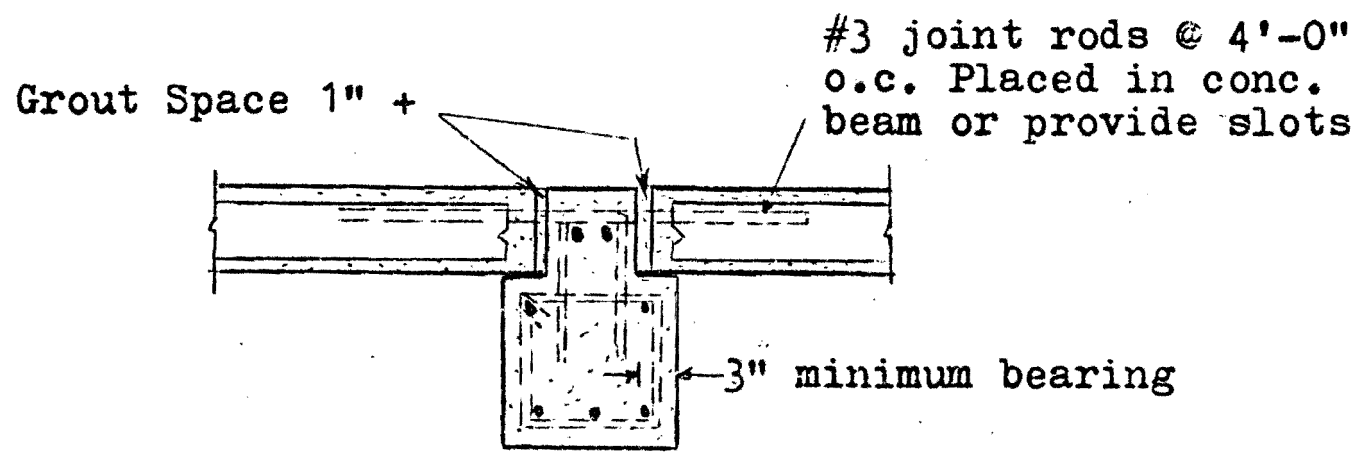

Figure 3.45. Typical Bearing on Interior Concrete Beam. Connection of Slab to Beam and Slab. (From Ref. 13)

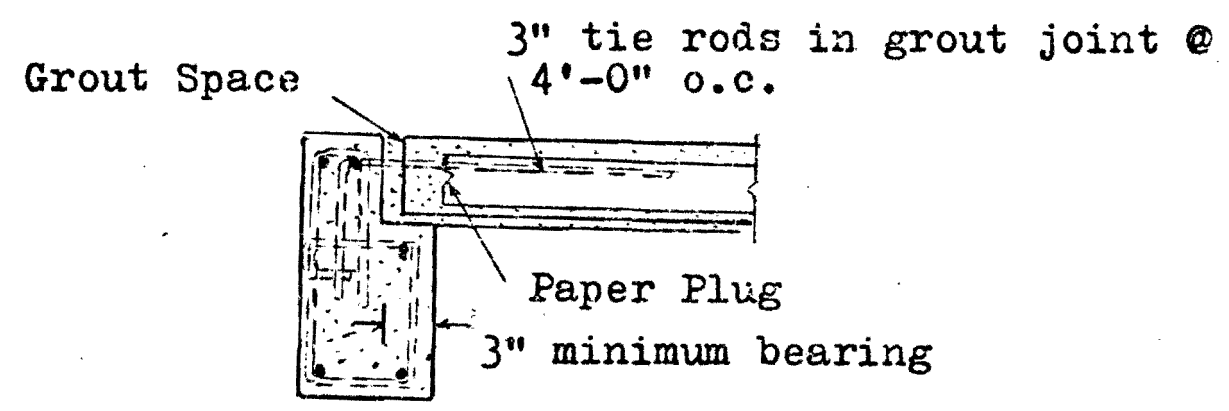

Figure 3.46. Typical Bearing on Exterior Concrete Beams. Connection of Slab to Beam. (From Ref. 13) 


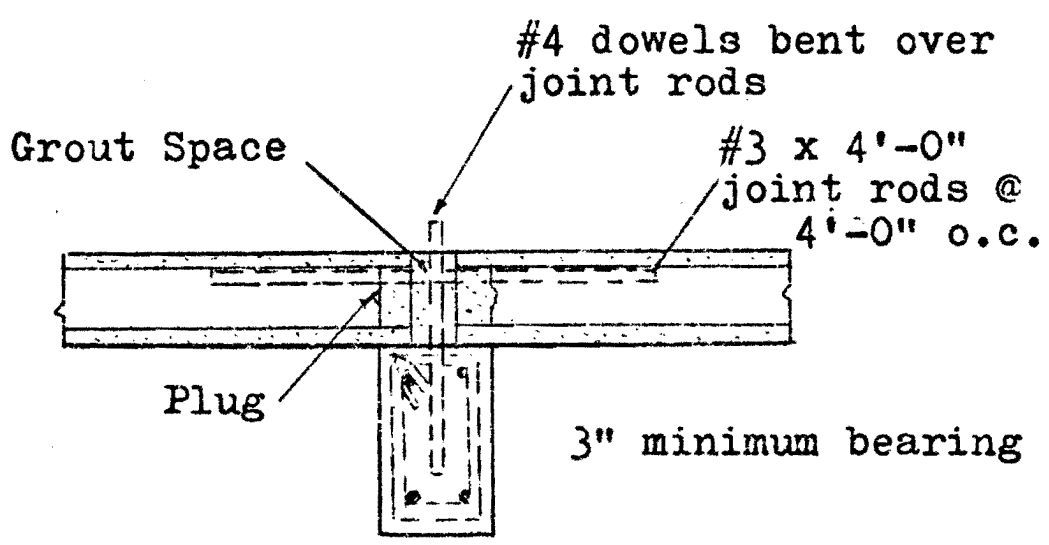

Figure 3.47. Typical Bearing on Interior Concrete Beam. Connection of slab to slab and beam. (From Ref. 13)

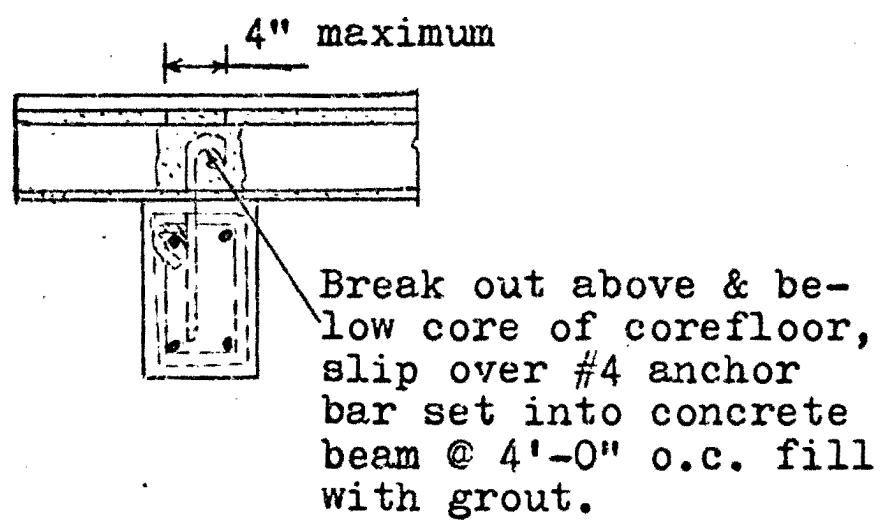

Figure 3.48. Typical Bearing on Exterior Concrete Beam with Cantilever. Connection of Slab to Beam. (From Ref. 13) 


\subsection{SEALANT MATERIALS AND JOINT}

\subsubsection{Sealant Materials}

For many years, oil based mastics or bituminous compounds and metallic materials were the orly sealants available. ${ }^{19}$ For many applications, these traditional materials do not perform well, ana, in recent years, there has been active development of many types of elastomeric sealants whose behavior is largely elastic, rather than plastic, and which are flexible rather than rigid at normal service temperatures. Elastomeric materials are available as field molded and preformed sealants. ${ }^{19}$ Though initially more expensive, they may be more economical cver an extended period due to longer service life. Furthermore, they can seal joints where considerable movements occur which could not have been sealed by the traditional materials.

Field molded sealants can be in one of the following forms :

1) Mastics, which are composed of viscous liquid rendered immobile by the addition of fibers and fillers. They do not usually harden, set or cure after application, but instead form a skin on the surface exposed to the atmosphere. $^{19}$

They are used in buildings for general cracking and glazing where only very small joint movements are antici- 
pated, and economy in initial cost outweighs that of maintenance or replacement. Polykutene and Polyiscbutylene mastics have a somewhat longer service life than do the other mastics.

2) Thermoplastics, either cold-applied, solvent or emulsion type, are set either by the release of solvents or the breaking of emulsion on exposure to air. They are primarily used as sealants for caulking and for horizontal and vertical joints in buildings which have smail movements.

Preformed sealants can be in one of the following

\section{forms :}

1) Gaskets and tapes, which are widely used sealants between glazing and its frame, around winaow and other openings in buildings, and at joints between precast concrete panels in curtain wells.

2) Compression seals, such as Neoprene, which is currently used for most sealing applications. For this purpose, the Neoprene formulation used must have special properties. For effective sealing, sufficient contact pressure must be maintained at the joint face. This requires that the seal experience some degree of compression. Good resistance to compression forces (i.e., the material must recover sufficieritly when released) is required.

To facilitate installation of compression seals, liquid Neoprene based lubricants are used. Compression seals are effective joint sealants over a wide range of tempera- 
ture in almost all application.

\subsubsection{Joint Design}

The location and width of joints that require sealing can be specified by considering the availability of sealant and the anticipated movement of the joints. If the sealants cannot take the anticipated movement, then the joint system for the structure must be redesigned to reduce the movement at the joints. Sealing systems currently available can accomodate (at increasing cost) movements up to about. 15-in. $(38.8 \mathrm{~cm}$.$) , and are presently being designed for$ even greater movements. Therefore, it is possible to design and specify a suitable sealed joint for almost any type of concrete structure.

The anticipated length (volume) changes within the structure must be determined and translated into joint locations and movements that not cnly fit the structural design and maintain the integrity between the individual structural units, but also, consider the fact that each type of sealant currently available imposes specific limitations. For both the shape of the joint that can be sealed, end the movement that can be accomodated, when using the applicable structural design codes and standards for movement calculations, it should be remembered that the cources of movement and the nature of movement, both long and short term, can be very important in other than simple structures. Both experience and judgement are necessary in the design of joints that 
function satisfactorily. ${ }^{19}$

In Reference 19, graphs are available to obtain joint widths for both field-molded sealants and compression sealants.

\section{4 .3 Joint Details}

The purpose of the joint is to provide weather tightness of the precast concrete members. Joints between precast panels may be divided into two basic types; one-stage joints, or two-stage joints. One-stage joints have one line of defense for their weatherproofing ability. This occurs normally in the form of a sealant close to the exterior surface. The advantage of this type of joint is that it generally provides the lowest first cost, and it is suitable for use between precast panels, as shown in Figs. 3.49 and 3.50 .

Two-stage joints, however, have two lines of defense for weatherproofing. The typical joint consists of a rain barrier near the exterior face and an air seal normally close to the interior face of the panels. The rain barrier is designed to shed most of the water from the joint and the air seal is the demarcation lire between outside and inside air pressures. Between these two stages is an equalization or expansion chamber which must be vented and drained to the outside. The two-stage joint is gaining acceptance, particularly for buildings, subject to severe climatic exposure or temperature and humidity control. ${ }^{19}$

A disadvantage of the two-stage joint for concrete 

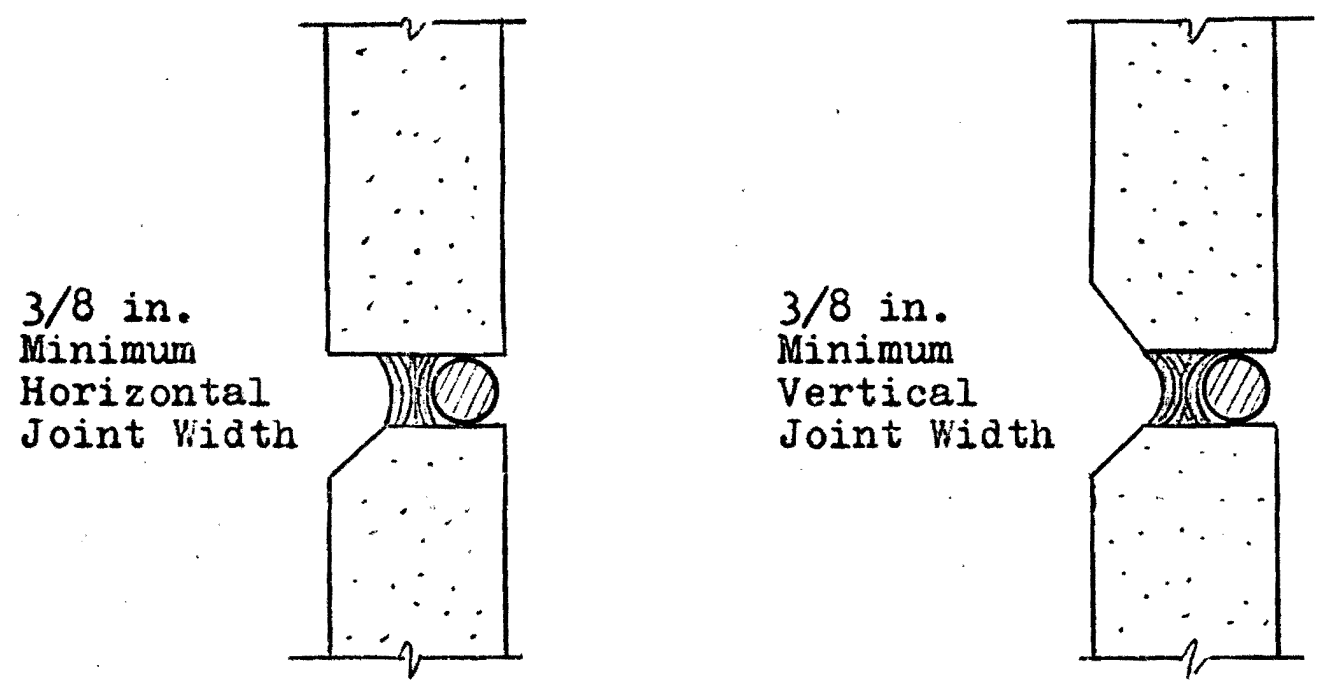

Figure 3.49. Recessed Vertical and Horizontal Butt Joint. (From Ref. 19)
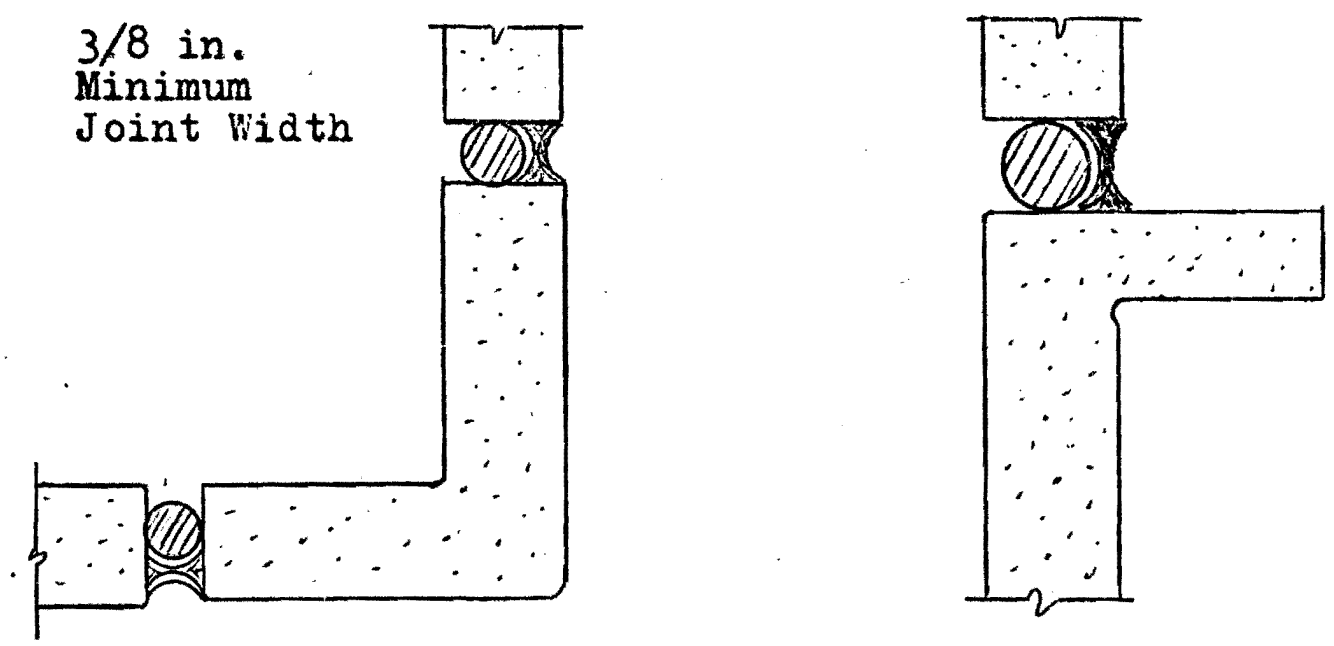

Figure 3.50. Corner Joint Detail and Panels with Narrow Ribs. (From Ref. 19) 
wall panels is the higher cost. For projects with good repititive joint design, properly integrated with other panel details, and having efficient production and erection procedures, it may well approach the cost of one-stage joint installations. ${ }^{19}$ In these instances, the safety factors and lower maintenance costs should be considered. Figs. 3.51 and 3.52 show two-stage joint details.

Some of the joint details for both floor and roof slab are shown in Fig. 3.53 . 
Air Seal Closed Cell Sponge Neoprene Square Strip or Rope 1.5 times the Theoretical Joint Width
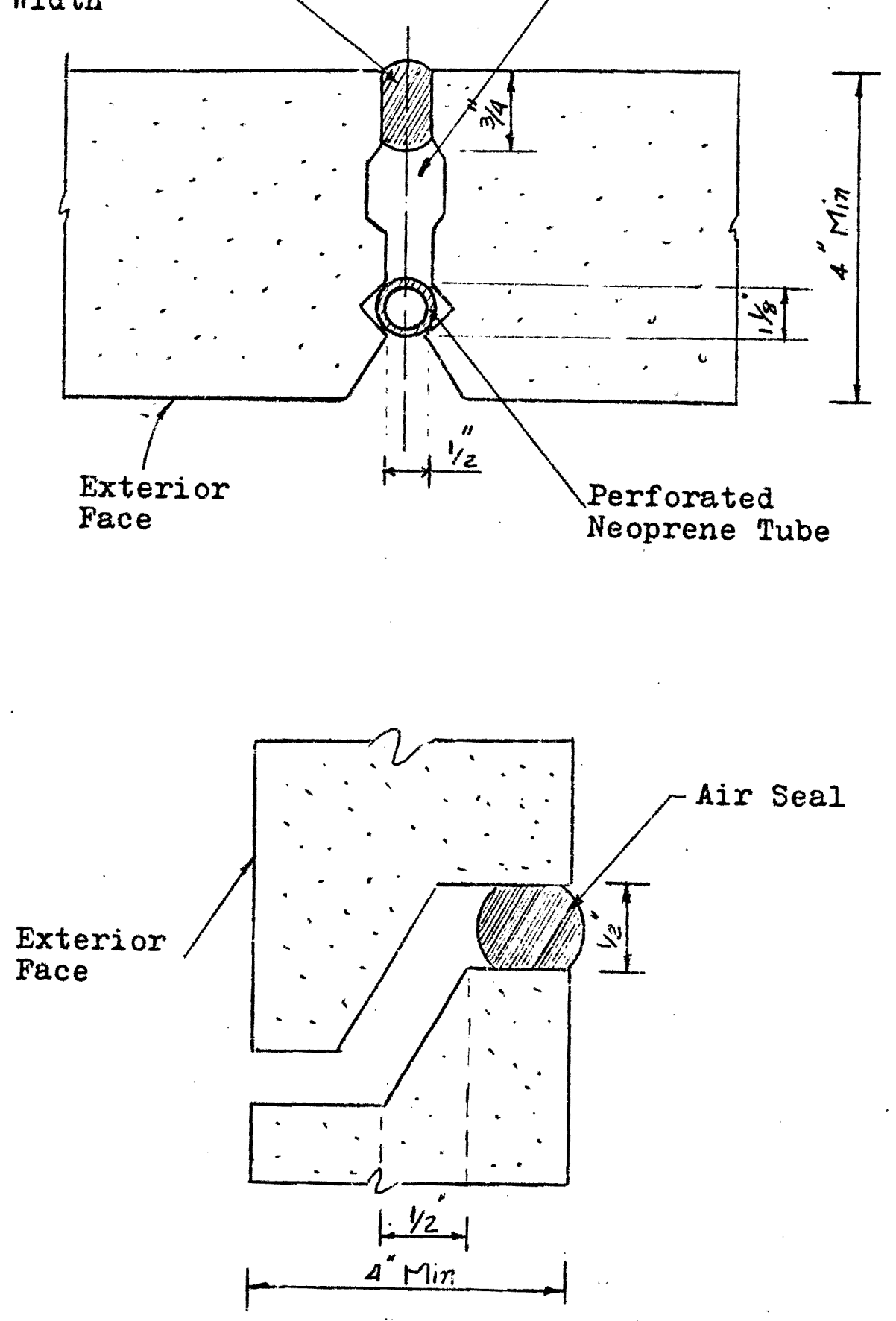

Figure 3.51. Two-Stage Joint Vertical and Horizontal Gaskets. (From Ref. 19) 

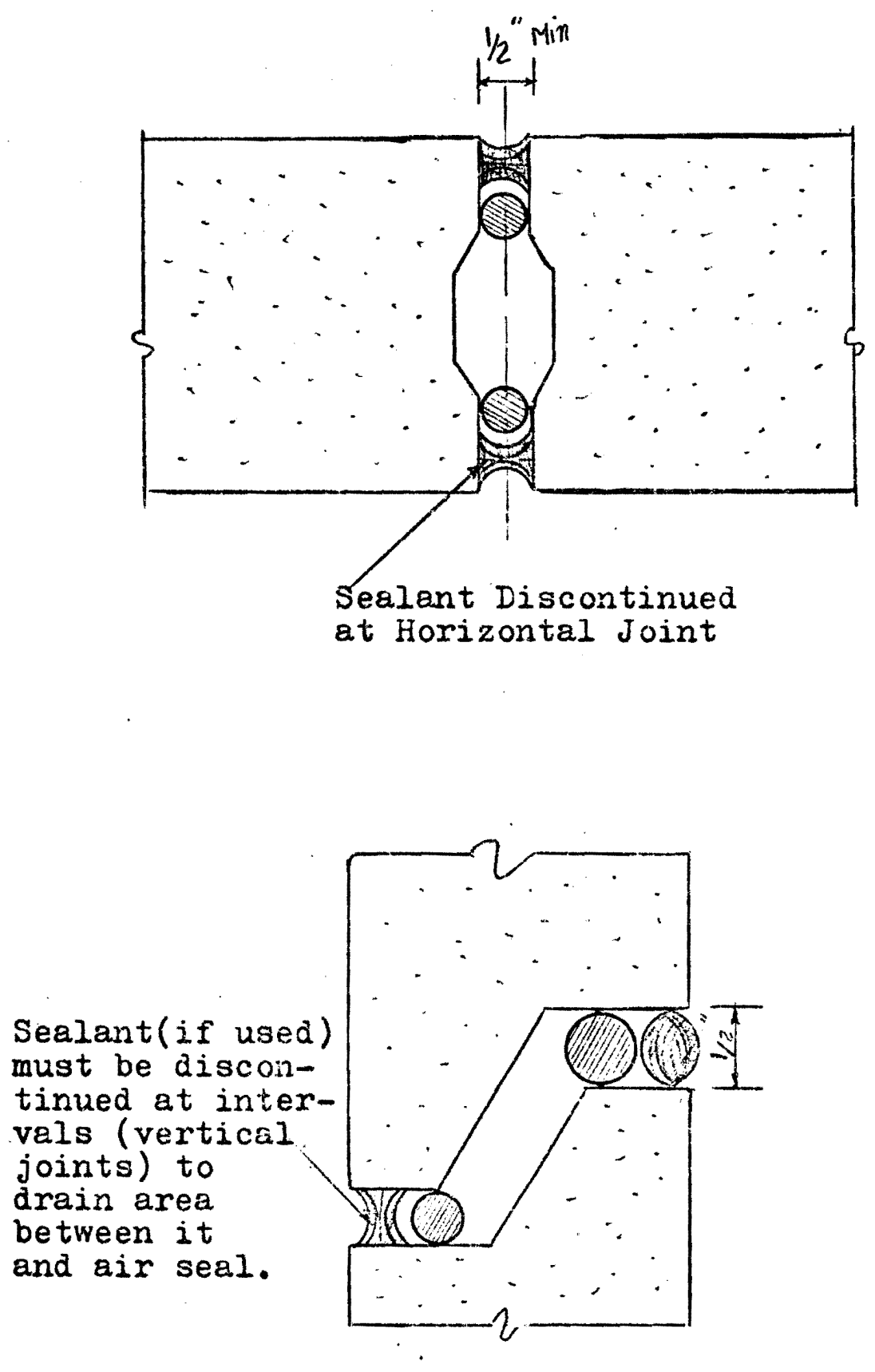

Figure 3.52. Two-Stage Joint Vertical and Horizontal Sealants. (From Ref. 19) 

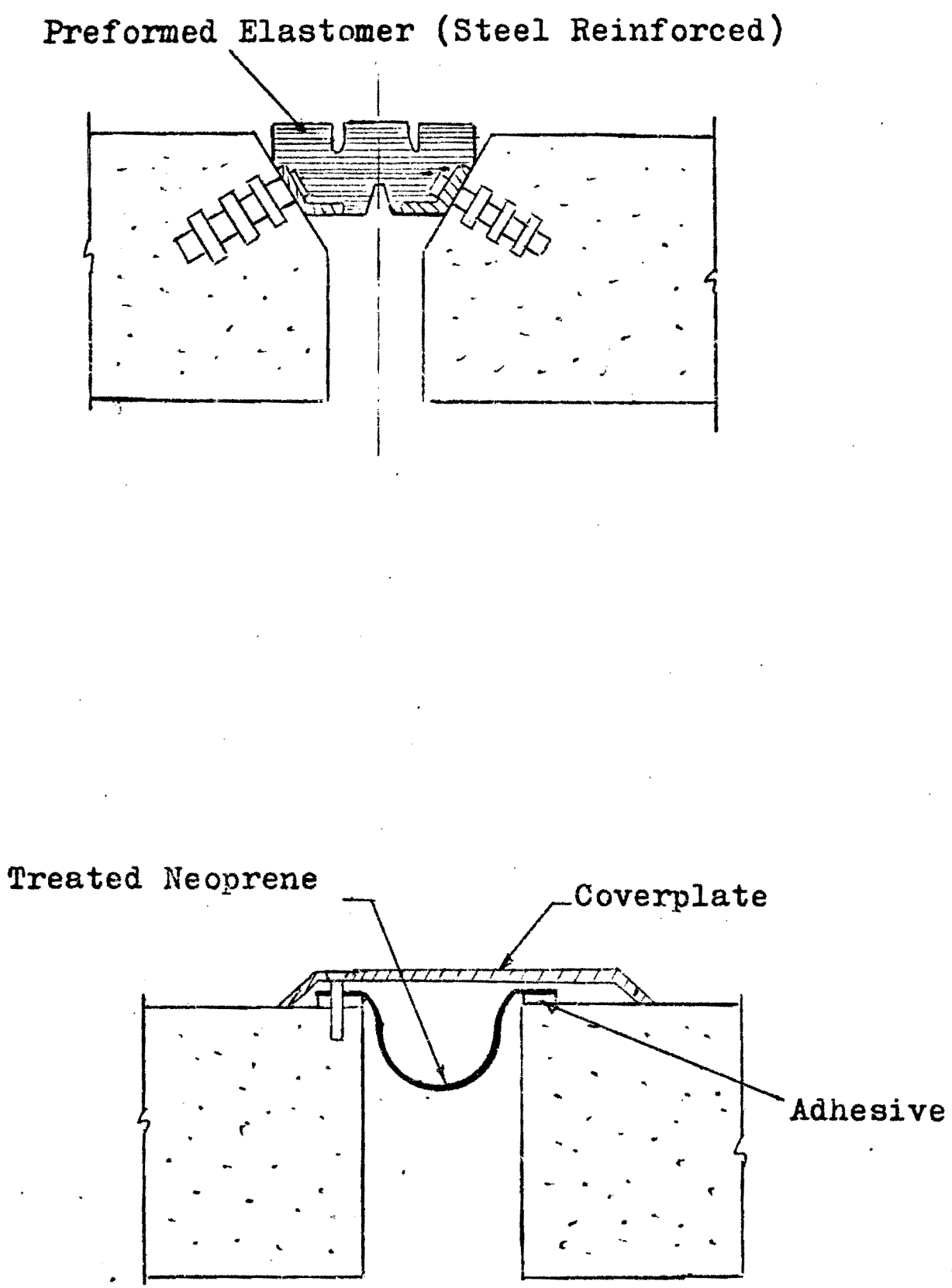

Figure 3.53. Floor and Roof Slab Joint Details. (From Ref. 19) 


\subsection{FIRE RESISTANCE}

The fire resistance of concrete makes it a very effective building material as compared to steel or wood. Concrete transmits heat very slowly, and, thus, is able to protect the steel reinforcement embedded within it from reaching the critical temperature at which its strength is no longer adequate. ${ }^{15}$ The protective coverage for steel is usually the critical item for the fire resistance of a concrete member. Failure of a reinforced concrete member often initiates from cracking and spalling, which exposes the steel to the fire. This action is due to differential expansion between the hot surface layers and the cooler concrete behind. It is also related to the opposing actions of cement, which shrinks due to a loss of moisture, and of the aggregate, which expands continuously during a temperature rise. 15

Factors affecting the thermal performance are: type of aggregate in the concrete; free moisture in the concrete, both absorbed and capiliary; and volume of concrete per square foot of exposed area. Fig. 3.54 shows the effect of various types of aggregate on the fire endurance of $43 / 4-i n$. Clab. ${ }^{5}$ Fire endurance is a measure of the elapsed time during which material or an assembly continues to exhibit fire resistance under specified conditions of test 
and performance. ${ }^{5}$ Fig. 3.55 shows relationships of slab thickness and type of aggregate to fire endurarce.

Factors affecting the structural performance are:

stress level in both concrete and steel; topping over the concrete and the reinforcing bars; tendency of aggregate and free moisture to cause spalling; and lateral restraint condition. 5

The effect of the concrete strength is more critical in columns then in slabs or beams, since this type of element is uniformly loaded in compression and surrounded by fire on all faces. In girders or slabs, the area exposed to fire is normally in tension so that protection of the reinforced steel is critical. Fig. 3.56 shows the effect of temperature on the modulus of elasticity and the compressive strength.

The fire resistance performance of ordinary reinforced concrete elements is affected by the rate of increase of the reinforcing steel temperature. This rate of increase is a function of the cover of the reinforcing bars and the size and shape of the cross-section in which they are embedded. These factors affect the time at which the reinforcing steel reaches a critical temperature (the temperature at which the yield point of the steel drops to the design stress in the steel). Fig. 3.57 shows the effect of temperature on the yeild strength of reinforcing steel. This figure indicates that for the intermediate grade bars most 
Fire Endurance - Hours

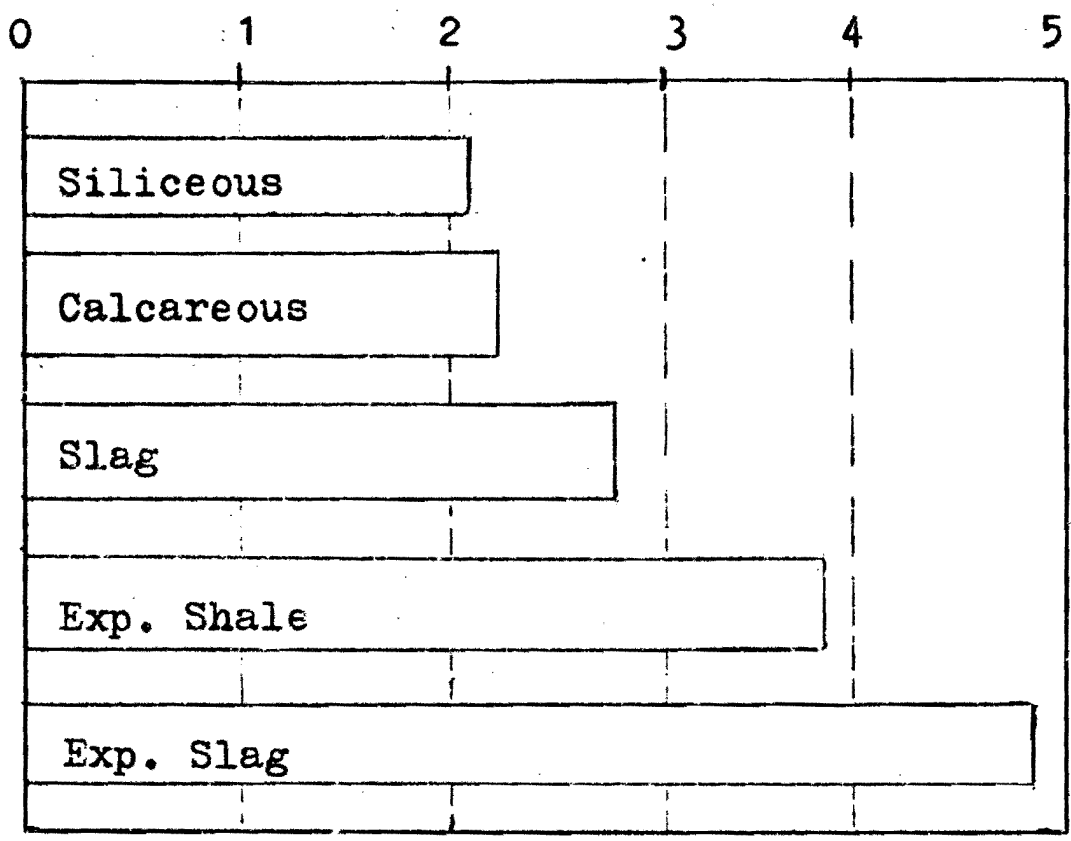

Figure 3.54. Effect of Varicus Types of Aggregate on the Fire Endurance of $43 / 4$-in. Slabs. (From Ref. 5)

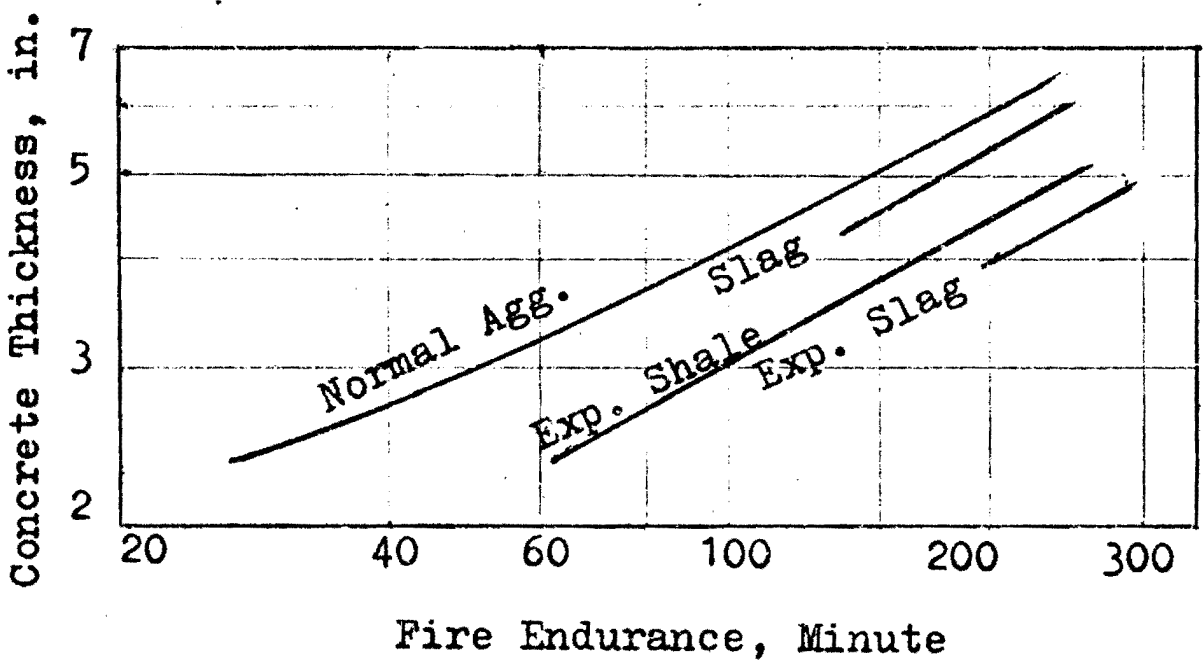

Figure 3.55. Relationship of Slab Thickness and Type of Aggregate to Fire Endurance. (From Ref. 19) 


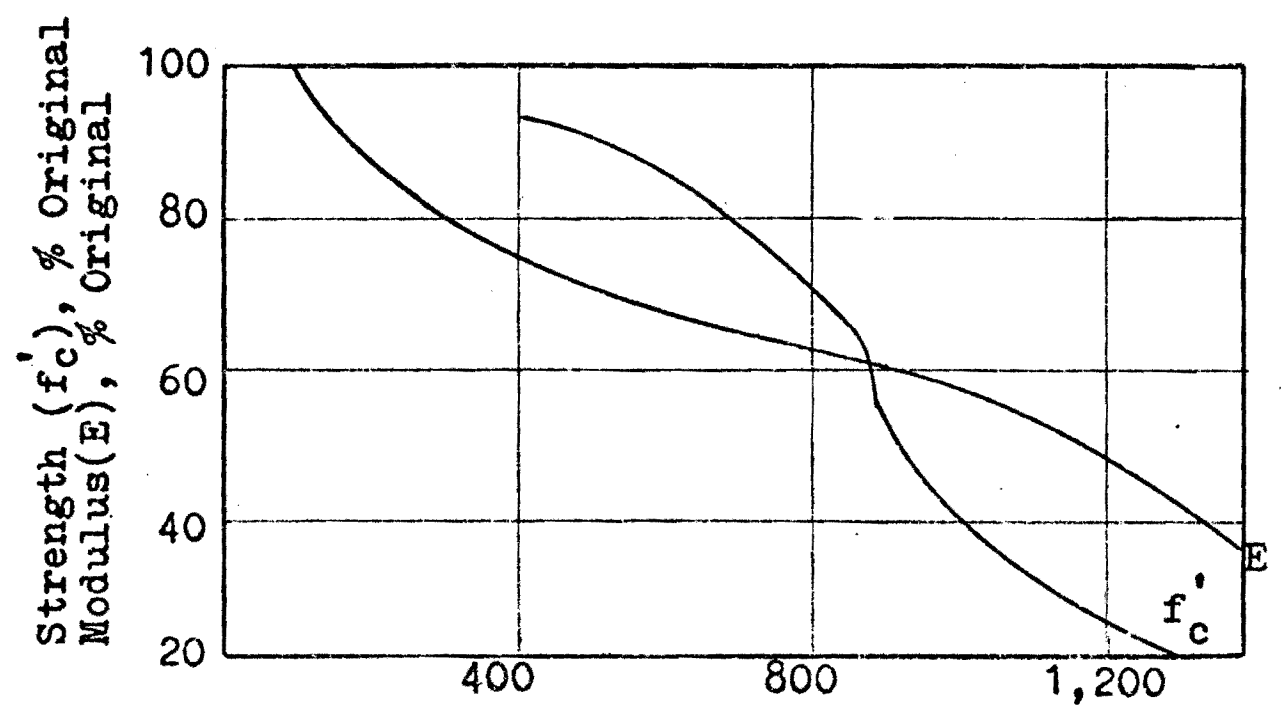

Figure 3.56. Effect of Temperature on Modulus of Elasticity and Compressive Strength. (From Ref. 5)

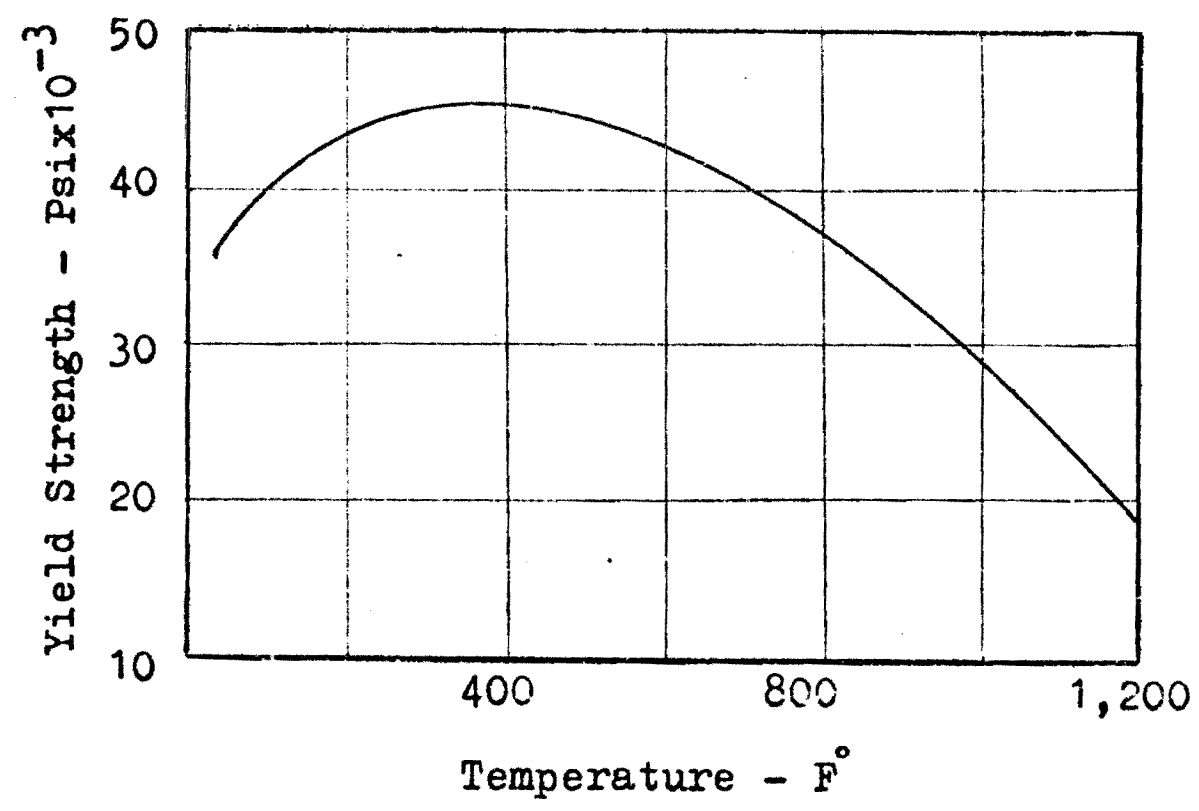

Figure 3.57. Effect of Temperature on the Yield Strength of Reinforcing Steel. (From Ref. 5) 
commonly used, the yield point will be approximately 18,000 Psi, when the bars have reached about 1,200 $\mathrm{F}$.

Since the temperature drop from the exposed surface is steep, small additions in the amount of cover have a large effect in the rate of temperature increase in the bars. Fig. 3.58 shows the actual thermal gradients of a 6.in. solid reinforced concrete slab. 5

Similar tests have been conducted on prestressed concrete. Results obtained for prestressed concrete are similar to the results of ordinary reinforced concrete. The most important difference is in the kind of steel used and the stress to which it is subjected. Prestressing steel contains a higher percentage of carbon, and is usually colddrawn to increase its strength, as discussed in Chapter 2. When subjected to the temperatures developed during a fire, it may become annealed and lose a large part of its normal strength. Tensile tests have shown that only about half of its tensile strength remains at $750^{\circ}$ to $850^{\circ} \mathrm{F}$, depending on the initial stress level; whereas for steel used in normal reinforced concrete, the corresponding temperature is about $1,000^{\circ} \mathrm{F}$. However, tests of prestressed beams, even when unrestrained, show a higher critical temperature (about $800^{\circ}$ to $1,000^{\circ} \mathrm{F}$ or more), which depends on the size and shape of the member.

The higher quality concrete used in prestressed concrete tends to be less permeable than ordinary concrete. Therefore, unless it is thoroughly dry when tested, spalling 
may also occur due to the greater rigidity of the higher quality prestressed concrete, especially for thin sections. When the exposed face is still cool, the high thermal stresses, in combination with the less yielding character of the high quality concrete, may cause spalling of thin slabs. 


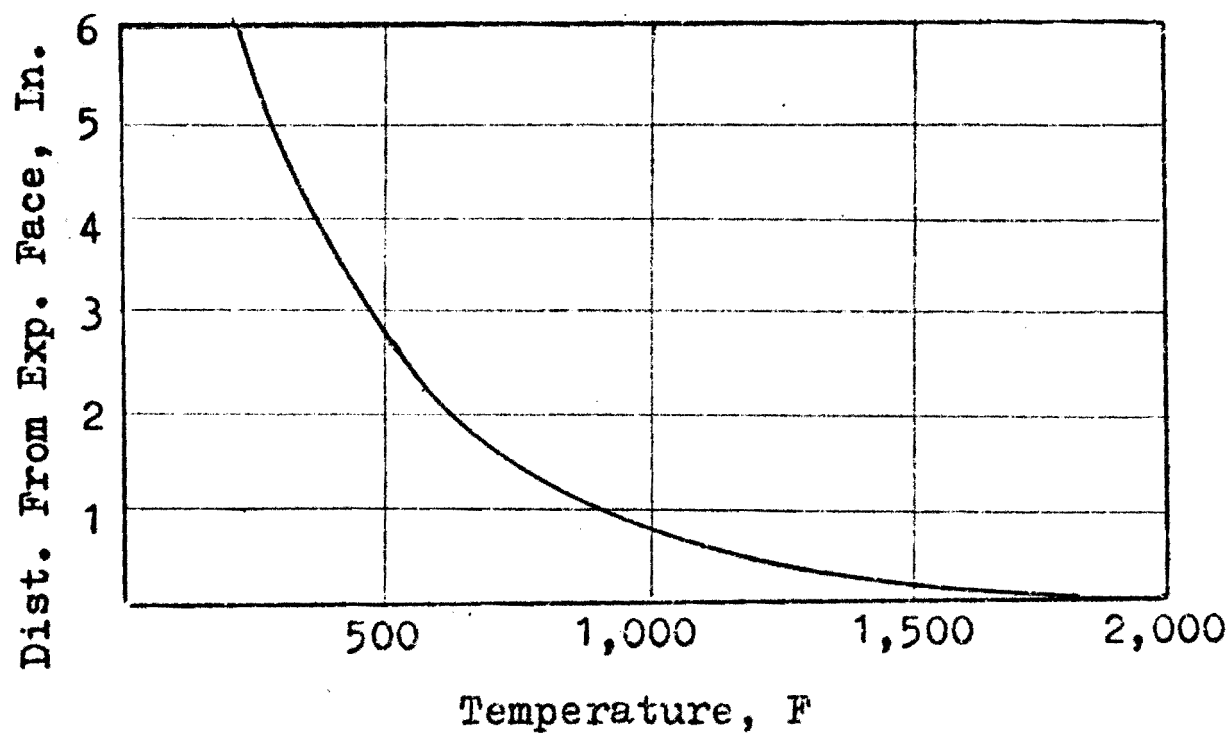

Figure 3.58. Thermal Gradient in a 6-in. Slab after 2 Hour Fire Exposure. (From Ref. 5) 


\subsection{THREE RECENTLY BUILT \\ STRUCTURES USING PRECAST \\ COINCKETE UNITS}

3.6.1 Case Study \#1

John Adams High School in Portland, Oregon will be studied as the first case study. The general contractor was Todd Building Co., the architect was Hawlett and Jamison A.I.A., and the structural engineer, Dirk it. Loojenga (Fig. 3.59). The precast prestressed concrete members were designed and produced under the supervision of George Laszlo, Chief Engineer, Empire Prestress, Inc. ${ }^{13}$

The structure is built in a $236,000 \mathrm{sq} . \mathrm{ft}$. area, with the entire stmacture above the foundation made with prestressed concrete. Columns are based on one cross-section shape. Exterior window panels are exposed dolomite aggregate concrete. Spandrel beams, walkway cover panels and railings are smooth concrete. Floor and roof construction is made of light-weight concrete prestressed Tees, $7.5 \mathrm{ft}$. wide to fit into a $15 \mathrm{ft}$. module line. The Tees used over the auditorium of the school are 120 ft., and over the gymnasium are $143 \mathrm{ft}$. Iong.

Thit main elements of this building are: 556 coiumns; 116 pcs. of window panels; 149 pcs. spandrel beams; 73 pcs. walkway cover panels (canopy panels); 79 pcs. walkway rails; 11 pcs. girders; and $232,000 \mathrm{sq}$. ft. $(21,500 \mathrm{~m})$ 
precast prestressed floor and roof Tees. There were also miscellaneous precast stair treads, etc.

The order of erection of members was first to erect $15 \mathrm{ft}$. columns at the center and at the window panels between the columns, then above these window panels a spandrel was placed, which was set into column notches. Then the floor or roof liee members were erected, one above each column and one in mid-span of the spandrel beams. In the two-story buildings, a similar method was repeated above the first floor level.

The basic section of all columns was a 24 " $x 24$ " cross with 8" of wall extended on each side. The column height was varied from $10 \mathrm{ft}$. to $28 \mathrm{ft}$. All columns received a smooth finisin to be painted in the field, and made of 5,000 Psi $(352 \mathrm{Kg} / \mathrm{sq} . \mathrm{cm}$.) herd róck concrete.

All window panels were the same size, $10^{\prime} \times 13^{\prime}$ $(3,05 \mathrm{~m} \cdot \times 3.96 \mathrm{~m}$.$) with four window openings. The specifica-$

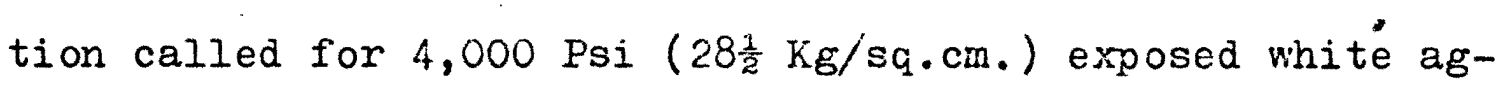
gregate concrete with some color addition. White dolomite aggregate was used, and excellent fsults were achieved with concrete retarder and sand blasting for exposing aggretate. Figure 3.60 illustrates a view of the window panels.

Spandrel beams were $8 " x 22^{\prime \prime} x^{1} 4^{\prime}-3 "(20.32 \mathrm{~cm} . x 55.9 \mathrm{~cm}$. $\mathbf{x} 43.4 \mathrm{~cm}$.$) , and made of 5,000$ Psi $(352 \mathrm{~kg} / \mathrm{sq} . \mathrm{cm}$.$) hard rock$ concrete with a smooth finish, ready to receive paint in the field. Some spandrel beams were $3^{\prime}-103 / 4^{\prime \prime}$ deep $(118.7 \mathrm{~cm}$.) 


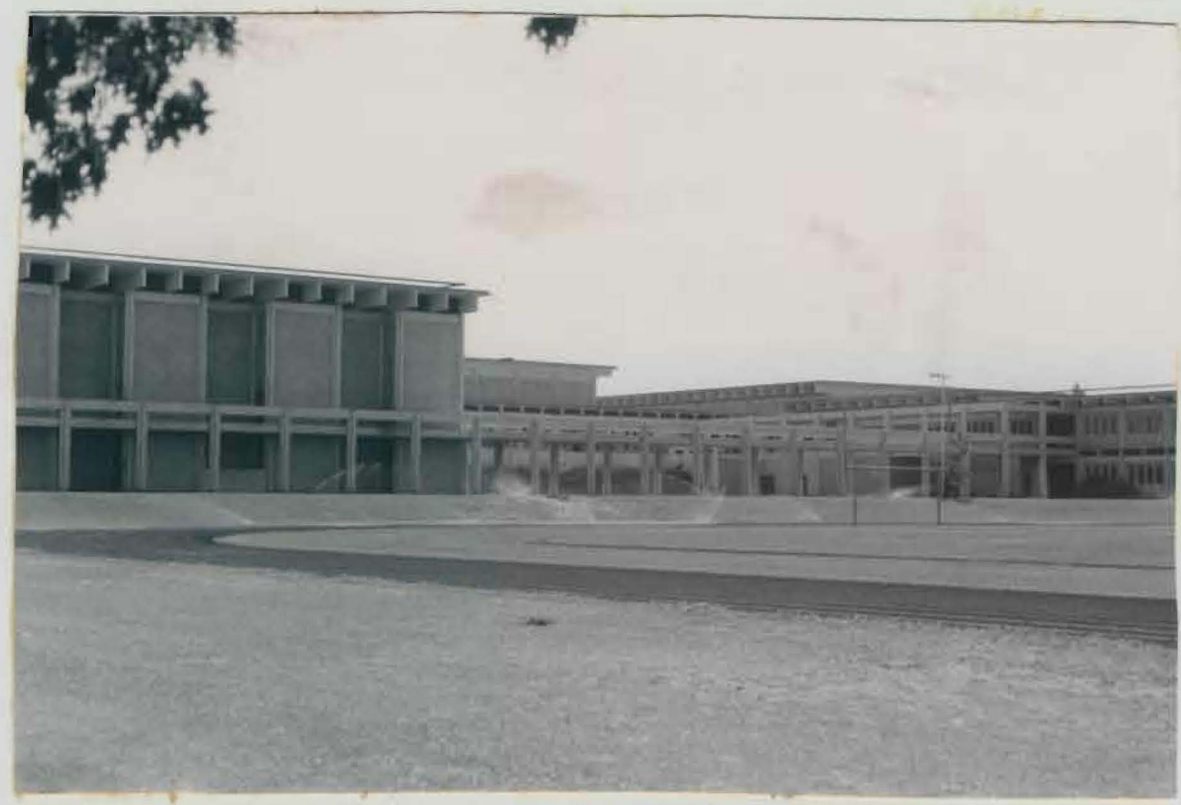

Figure 3.59. General View of Jon Adams High School.

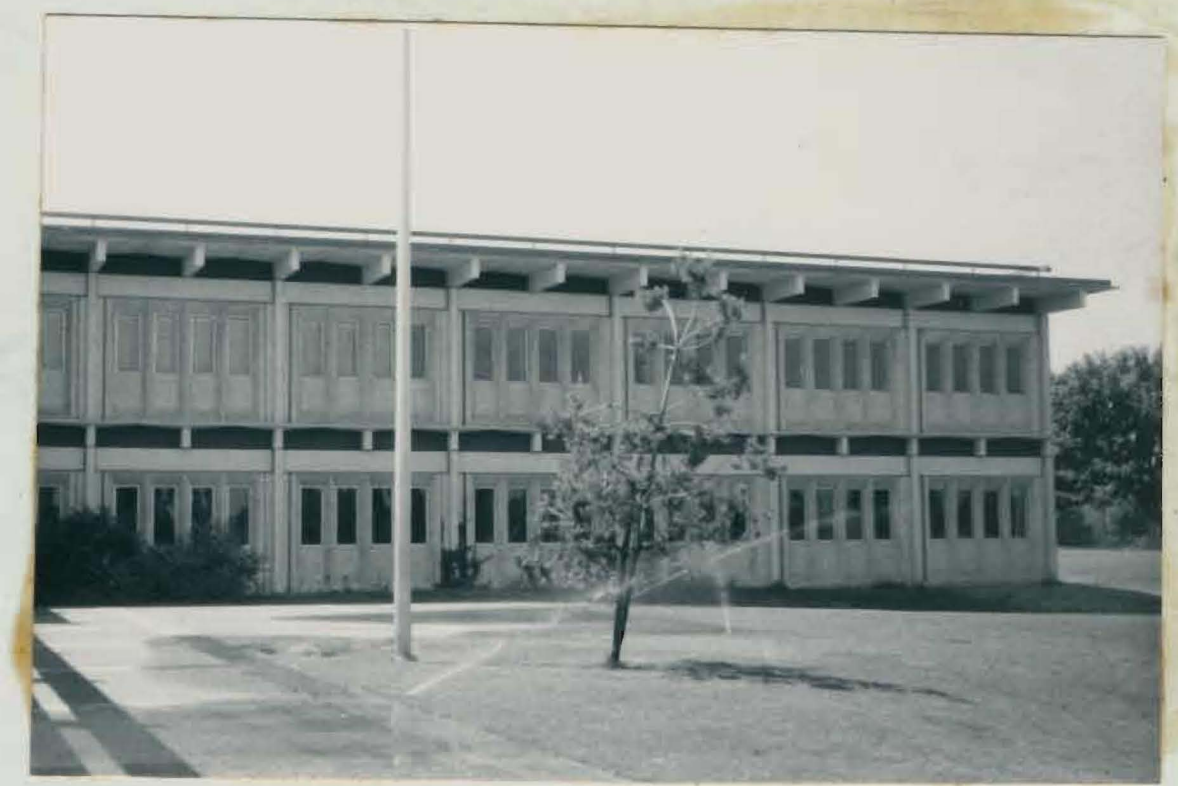

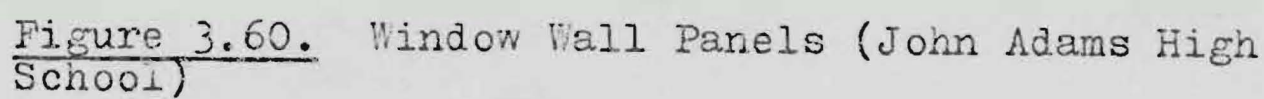


and received a scuiptured face. The sculpture was done by an artist, and these panels were produced by plastic suction-form method. Figs. 3.61 and 3.62 skow the spandrel beams.

Walkway cover panels were probably the most interesting and ingenious sections. They were $14^{\prime}-13^{\prime \prime} \times 14^{\prime}-3^{\prime \prime}$ ( $4.34 \mathrm{~m} . \times 4.34 \mathrm{~m}$.$) waffle slab with a cross rib at midspan.$ The perimeter beams and cross ribs were 8 "x22" $(20.32 \mathrm{~cm}$. $x$ $55.88 \mathrm{~cm}$.$) with 3^{\prime \prime}$ thick slabs $(7.62 \mathrm{~cm}$.$) . These canopy$ panels were produced in steel forms, and made of hard rock aggregate 4,000 Psi $(281 \mathrm{Kg} / \mathrm{sq} . \mathrm{cm}$.) concrete with smooth finish. Figs. 3.63 and 3.64 illustrate the walkway cover panels (waffle slab).

Floor and roof Tees were $7.5 \mathrm{ft} .(228.5 \mathrm{~cm}$.$) wide to$ fit into the $.15 \mathrm{ft}$. module lines. Depth was varied according to load and span requirements from 18 " to $48 "(45.7 \mathrm{~cm}$. to $122 \mathrm{~cm}$.$) . The floor spans were 45 \mathrm{ft}$. or $60 \mathrm{ft} .(13.72$ m. and $18.3 \mathrm{m.})$; roof spans averaged $90 \mathrm{ft} .(27.45 \mathrm{m.})$ in length. The roof Tees above the auditorium were 44" deep $x$ $120 \mathrm{ft}$. Iong ( $111.8 \mathrm{~cm} . \times 36.6 \mathrm{m.})$, and above the gymnasium 48" deep $\times 14.3 \mathrm{ft}$. Iong (122 cm. $x 43.61 \mathrm{~m}$ ) Due to slendemess and great length of these Tees, special attention was made in production and handlirg. To eliminate sideways (horizontal) bending and excessive torsion during hauling, it was necessary to design a special bracing system. This system included a heavy steel angle bolted to each end on 


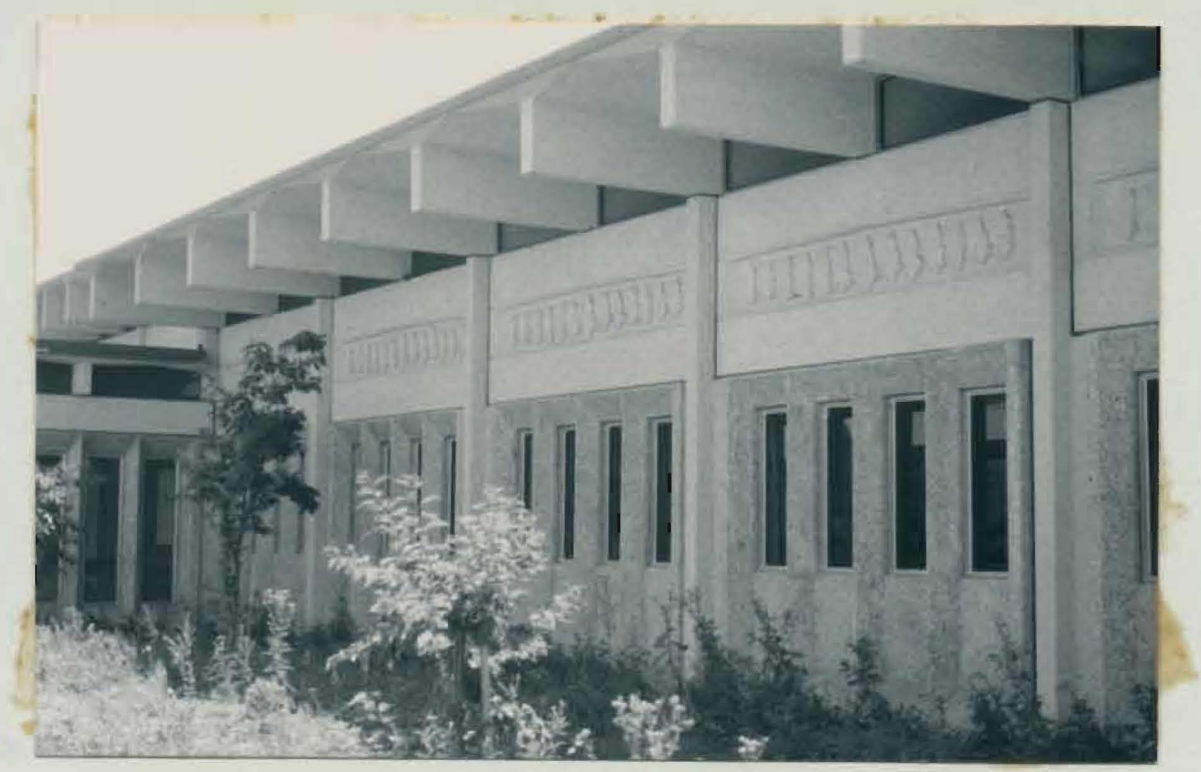

Figure 3.61. Spandrel Beams (John Adams High School). 


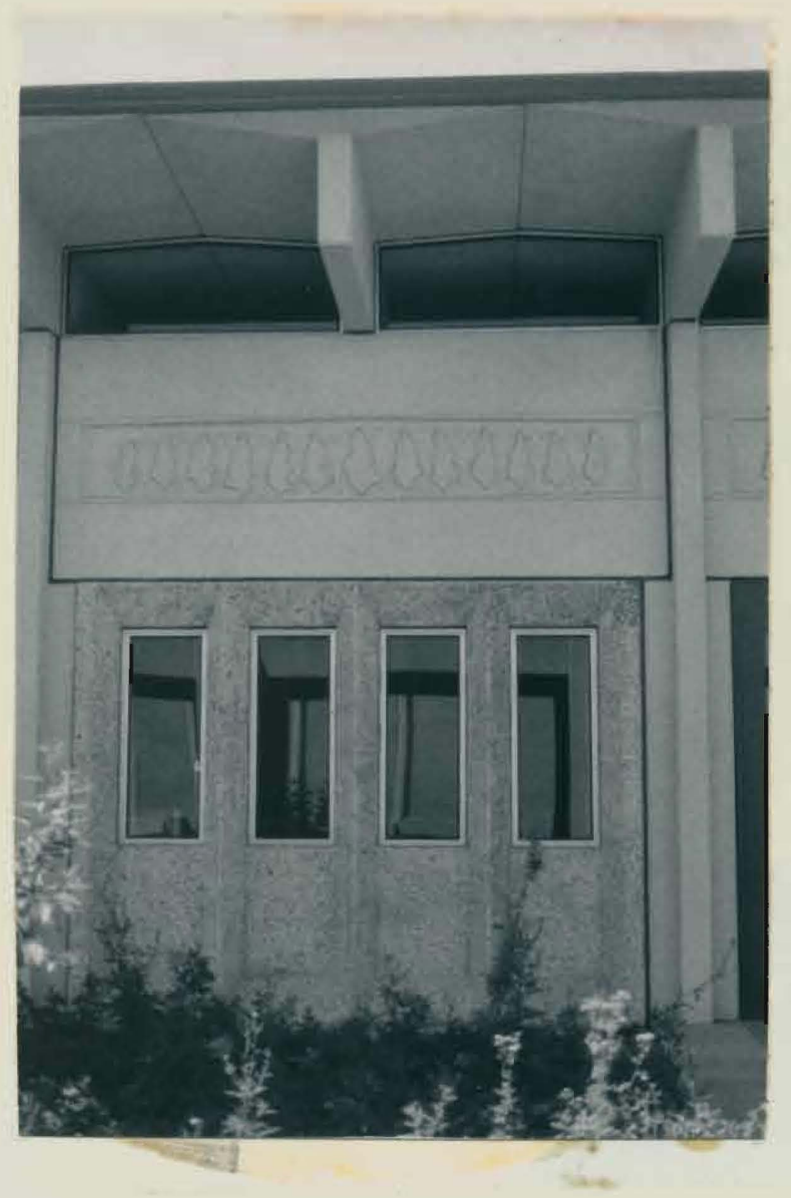

Figure 3.62. A Close-Up of a Spanarel. Beam (John Adams Hign School). 


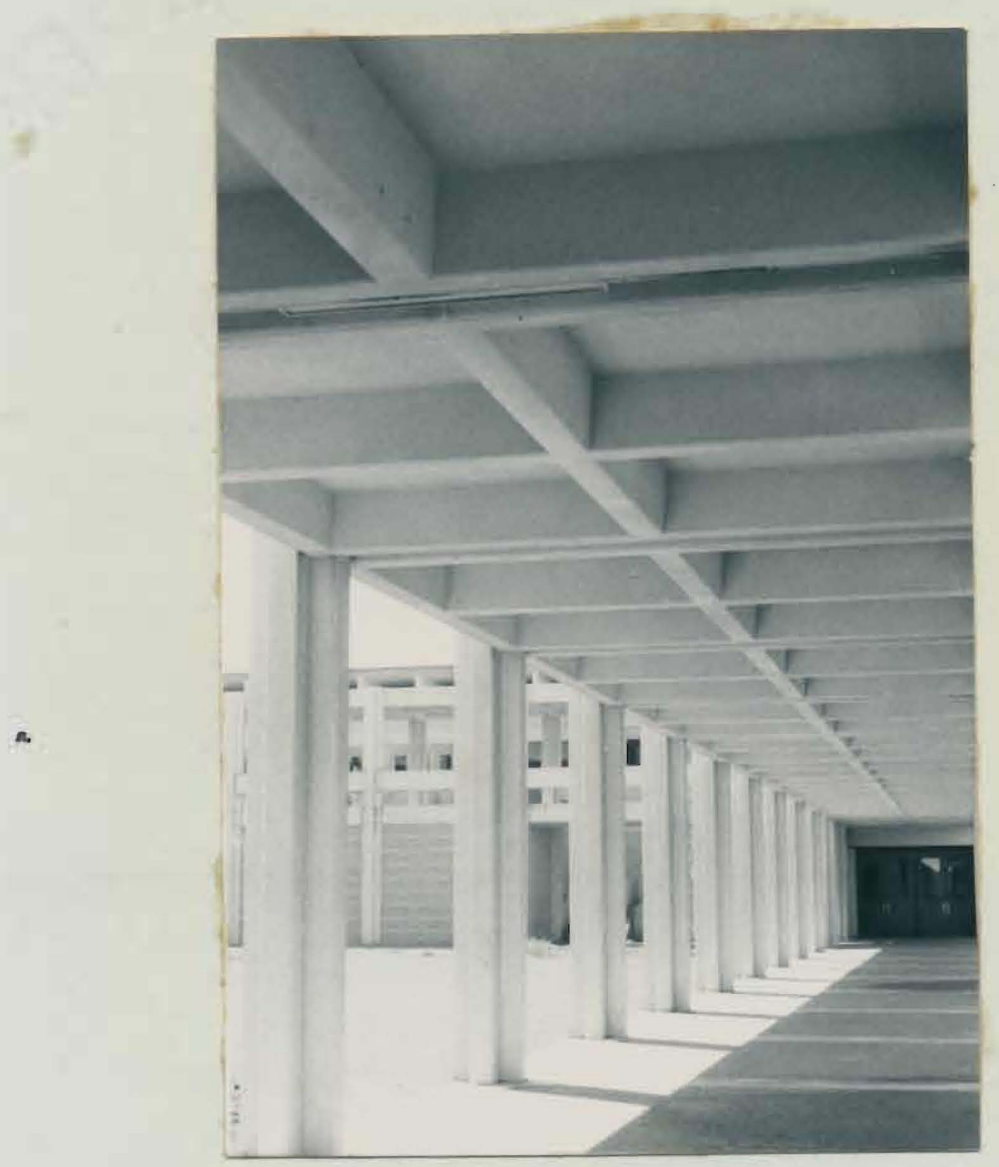

Figure 3.63. Walkway Cover Panel Used for First Floor (John Adars High School). 
113

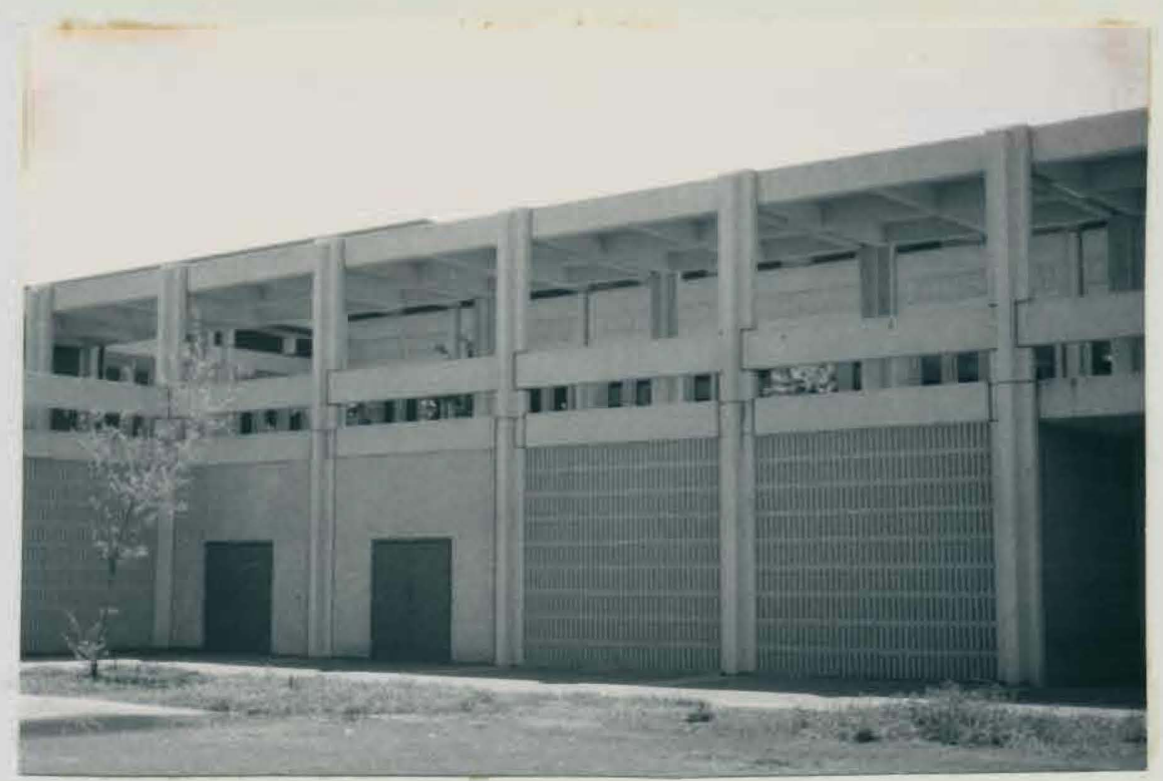

Figure 3.64. Walkway Cover Panel. Used for the Second - Floor (John Adans High School). 
both sides of the web. A $3 \mathrm{ft}$. long channel was then bolted to the web at the neutral axis at mid-span, and two $\frac{1}{2} "$ dia. $270 \mathrm{Ksi}$ strands were stressed from the end to give a horizontal truss to both sides of these long Tees. Just before erection, these strands were bumed. All roof Tees, including the long spans, were light-weight aggregate concrete, with the strength of 5,000 Psi minimum at 28 days ( $352 \mathrm{Kg} / \mathrm{sq} . \mathrm{cm}$.$) . Figs. 3.65$ and 3.66 illustrate Tee beams of the gymnasium and auditorium.

It was found that in short members (under $90 \mathrm{ft.}$ ), the camber can be calculated within 10\% accuracy in light-weight concrete; however, the longer members always achieved less camber than calculated.

Welded and pinned comnections were used in order to transfer the horizontal forces to interior shear walls and to the foundation. In larger sections, there were some cast-in-place rigia frames to resist horizontal forces. The window panels with their large sized openings were also designed for taking lateral forces. The larger sections were separated by means of expansion joints, using bolted connections with slotted holes, allowing enough movement for theremal and horizontal forces.

For simplicity, the same general type of connections were used. The columns were pinned by means of one or two \#8 rebars, extending into the foundation from the column base, and welded on exterior edges. The pin resisted hor- 


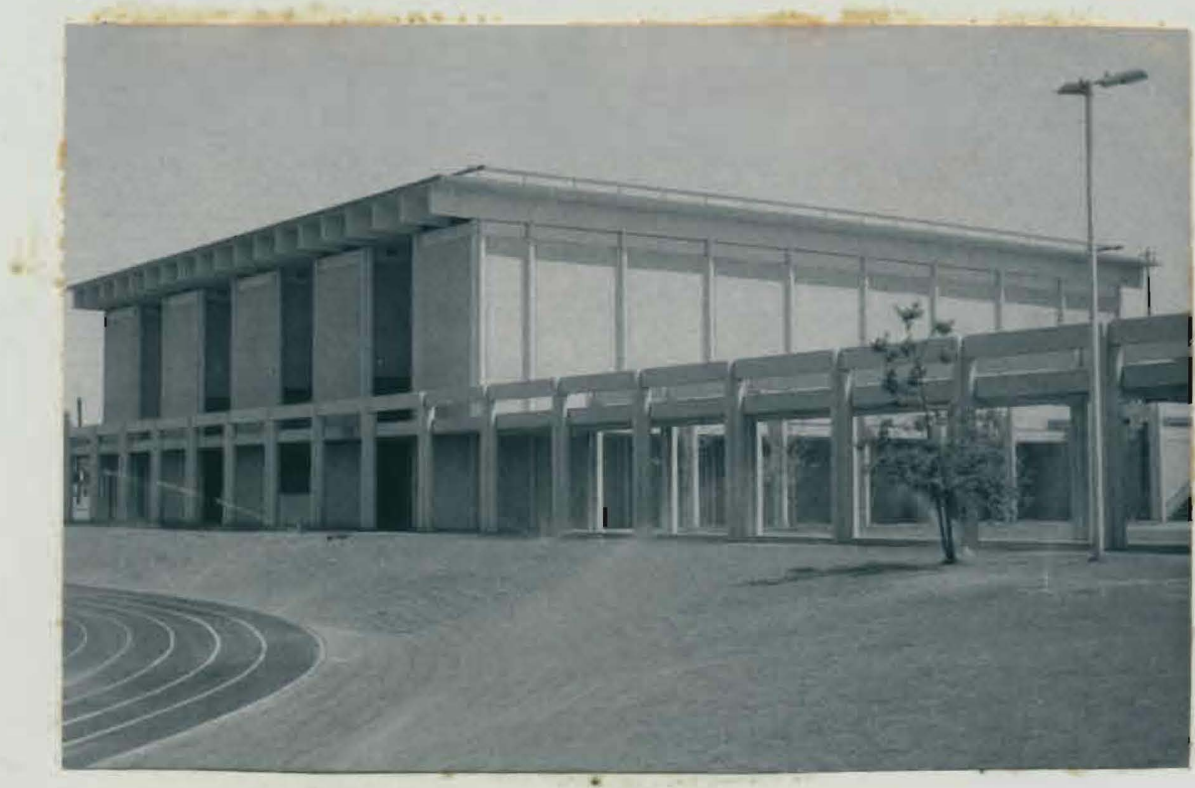
$\frac{\text { Figure 3.65. Tee Beam of Gymnasium (John Adams High }}{\text { School). }}$

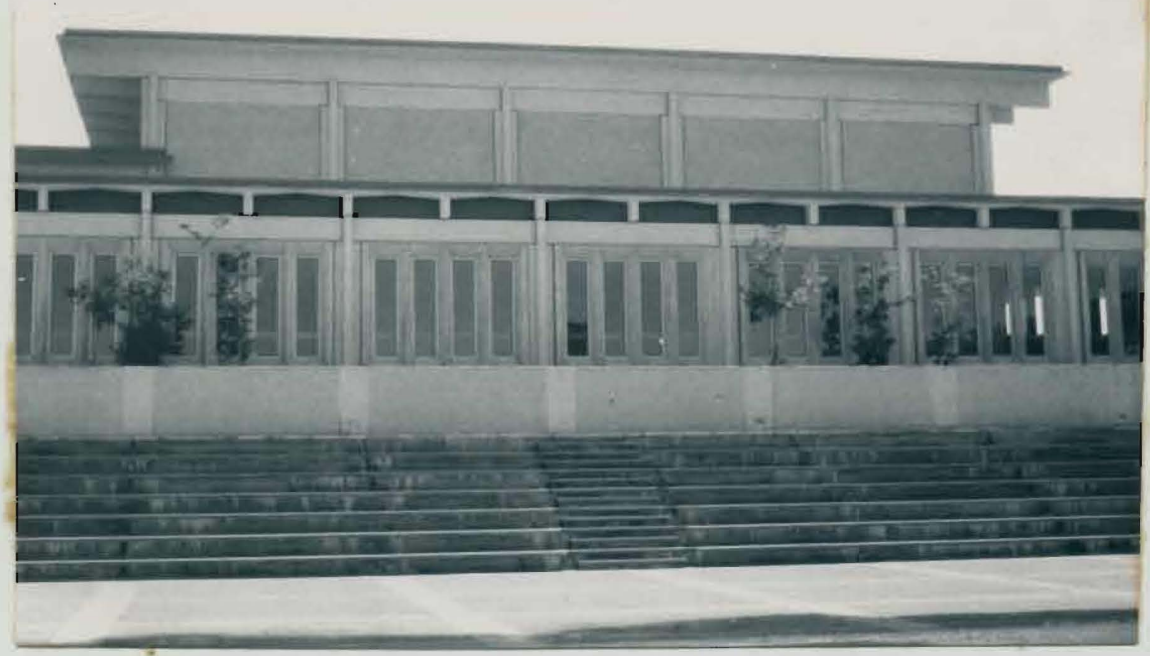

Figure 3.66. Tee Beam of Auditorium (John Adams Kigin 
izontal shear at the base, and the welded connection provided adequate rigidity against bending. Window wall panels were welded to continuous footing and to the columns at the sides. Floor and roof Tees had one or two vertical downspouts cast into the ends to receive $\# 8$ pins from column and spandrel beams, which were grouted into these holes. Generally speaking, the simplicity of erection and connection of precast building parts greatly contributed to cost reduction, and made the building architecturally attractive.

\subsection{Case Study \#2}

The second case study considered is the Harshall Union Manor Building in Fortland, Oregon. General contractor was Minden Construction Inc, and the architect was Henry Grey Brook. Interviewed was Jim Hendren, Superintiendent.

This building consists of 213 apartments in 12 stories. All members above the foundation are precast concrete. Two general views of the building are shown in Figs. 3.67 and 3.68 .

This building consists of wall panels, interior bearing walls and core slab. Interior shear walls and core slabs axe prestressed, while wall panels are ordinary reinforced concrete. Wall panels are $9^{\prime} \times 16^{\prime} \times 6^{\prime \prime}$ for exterior walls, using steel pipe cores for reinforcement, as show in Fig. 3.69. The interior walls are $12^{\prime} \times 16^{\prime} \times 12^{\prime \prime}$. These walls are bearing walls, and are designed to carry 


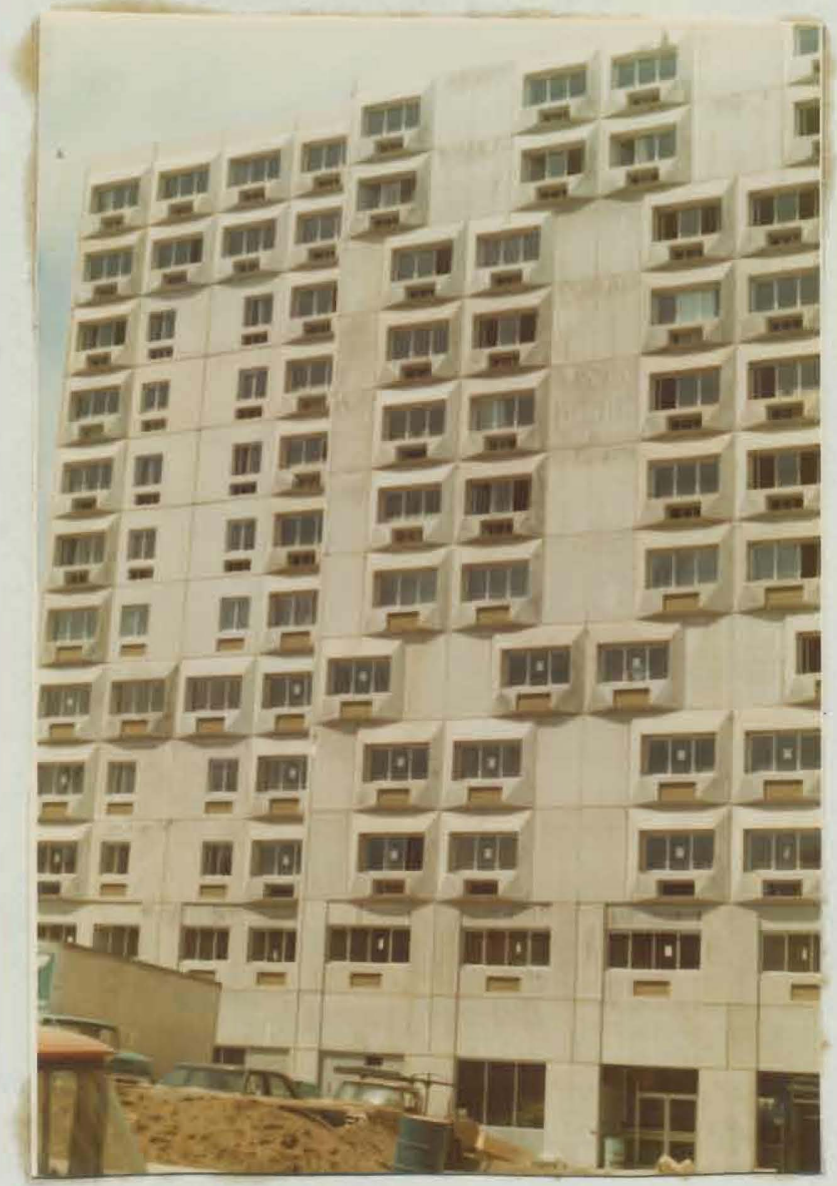

Figure 3.67. General View of Marshall Union Manor Builuing. 


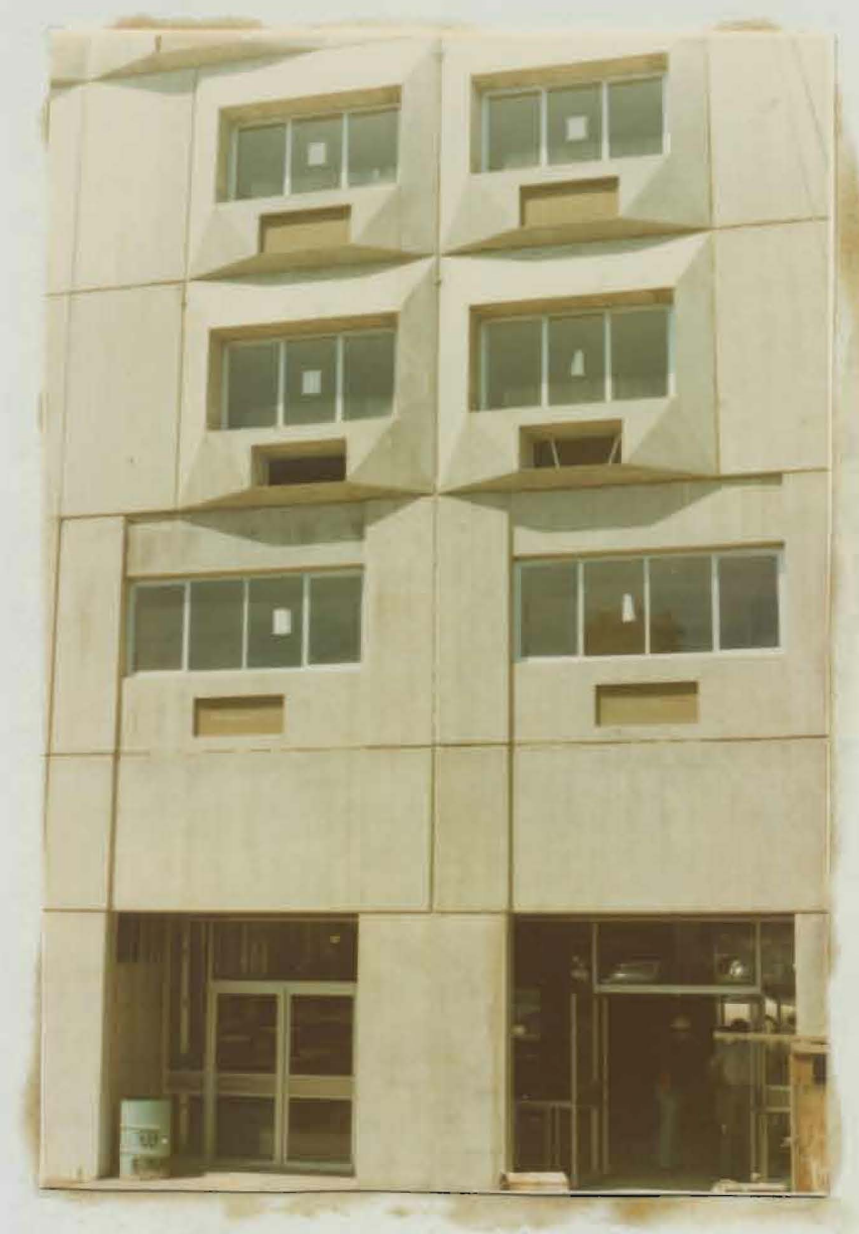

Figure 3.68. Another View of Marshall Union Manor Building. 
lateral shear forces necessary for Zone 2. Slabs are core slabs, all of which are precast prestressed concrete, and sizes are $8^{\prime} \times 32^{\prime} \times 12^{\prime \prime}$ for bottom floors and $8^{\prime} \times 32^{\prime} \times 8^{\prime \prime}$ for top floors. Fig. 3.70 shows the typical cross-section of core slabs. The hollow-cores are used for mechanical pipes and electrical wiring.

Figs. 3.71 and 3.72 illustrate typical details of slab to wall panel and slab to slab conrections.

Another interesting detailing was covering the narrow strip gap which, in some areas, could not be covered by the slabs, since the modular slab width was kept constant at 8'-0". These gaps usually varied from 2" to 6" in width, and $32^{\prime}-0 "$ in length (slab length). Fig. 3.73 illustrates this detail. Accoraing to Mr. Jim Henderson, Superintendent, construction time was reduced by about one-half by using precast members rather than cast-in-place members.

\subsubsection{Case Study \#3}

The third case studied was a garage built in Bridgeport, Connecticut (Fig. 3.7.4). 9 The garage was designed by Fletcher Phompson, Inc., Bridgeport architects, with Lathrop Douglass as consuiting architect. It was built for a capacity of 2,000 cars, and was completed in less than a year. It is $722 \mathrm{Ft}$. long and $123 \mathrm{ft}$. wide, seven stories high and contairs $635,000 \mathrm{sq}$. ft. of floor space. The actual construction and design costs were only $\$ 3.1$ million, or just slightly over $\$ 1,500$ per parking stall. 


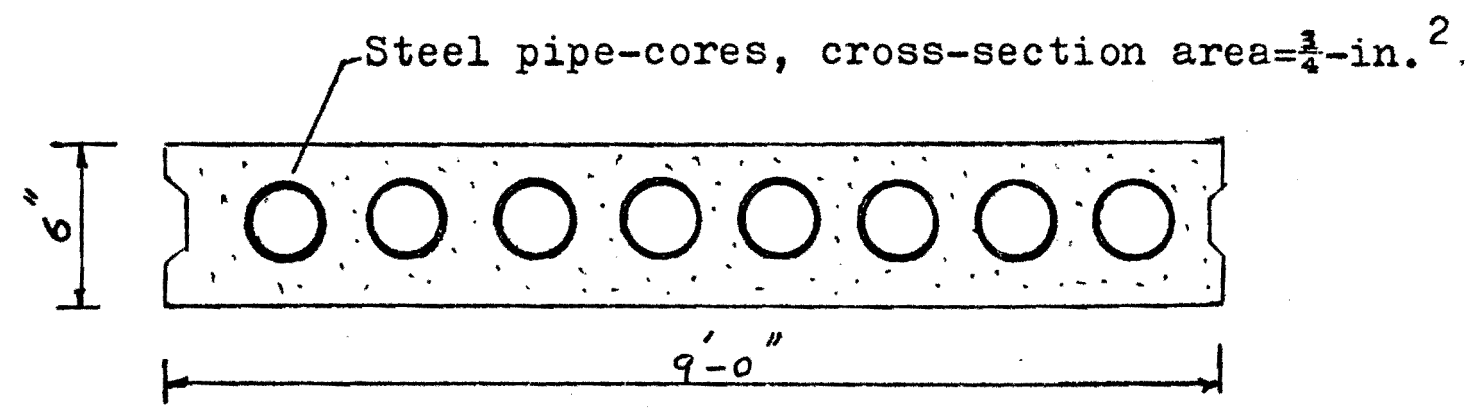

Figure 3.69. Typical Cross-Section of Exterior Bearing WaII.

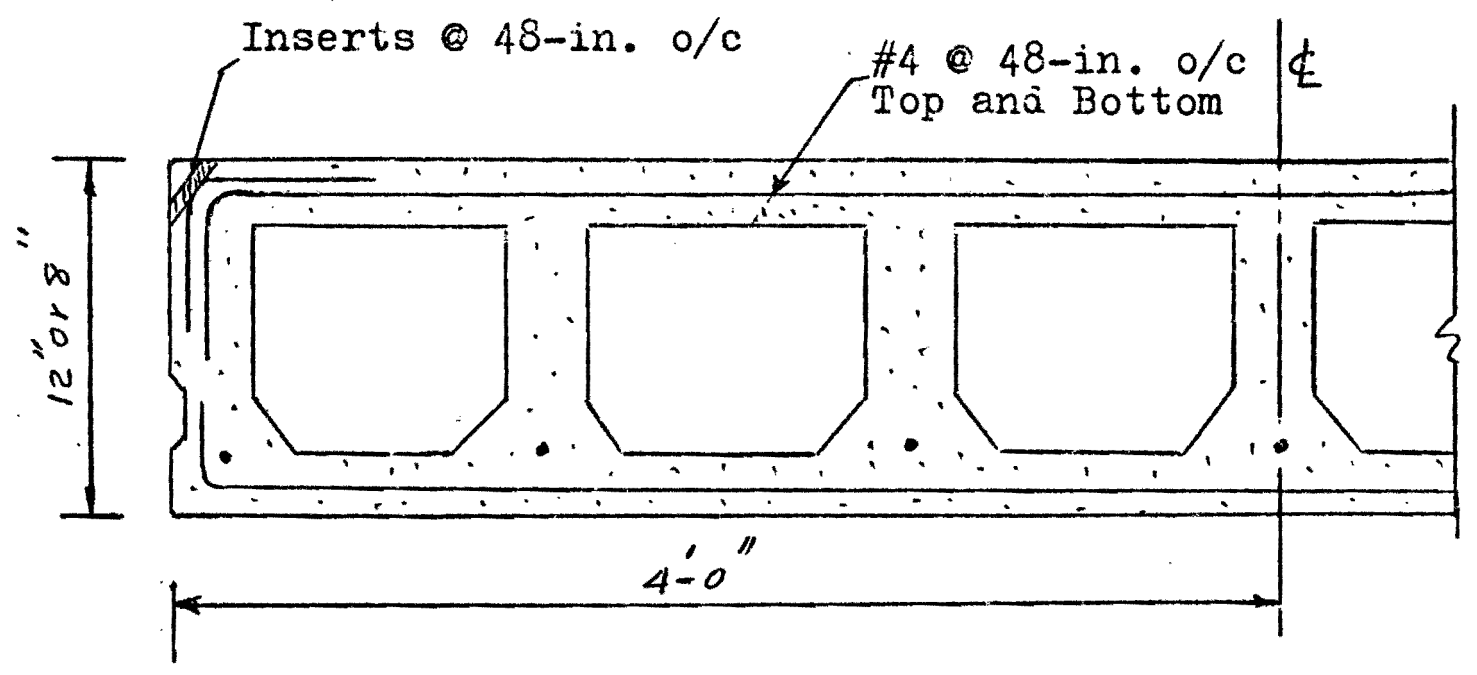

Figure 3.70. Typical Cross-Section of Core Slabs. 


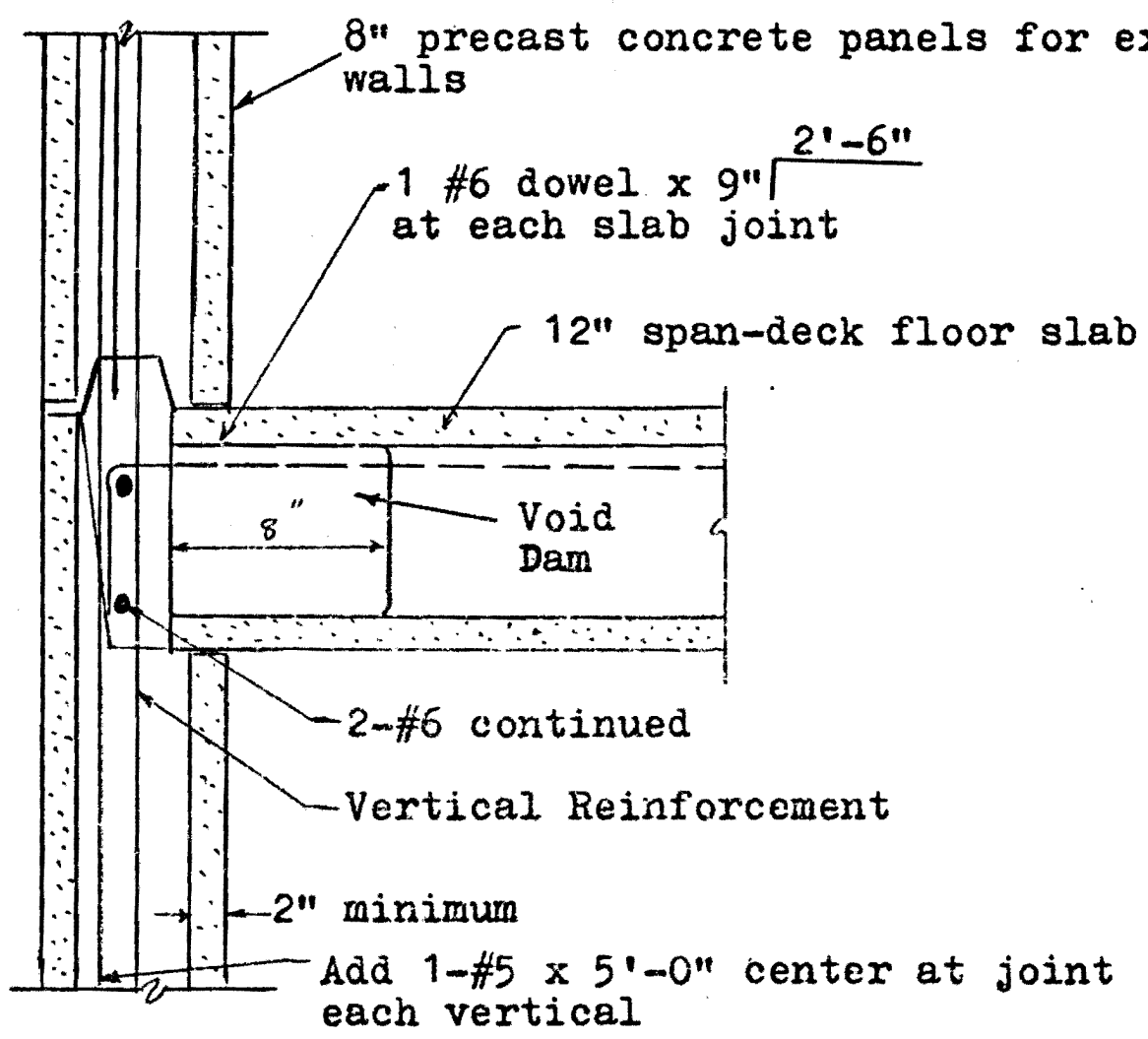

Figure 3.71. Typical Slab to Hall Panel Connection

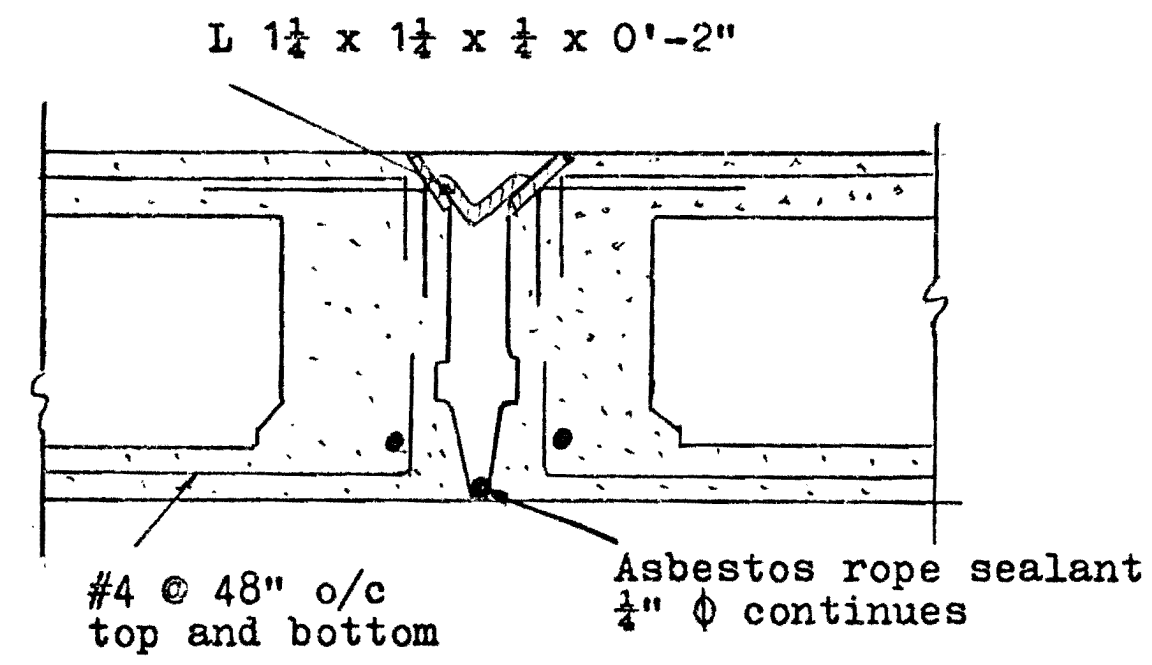

Figure 3.72. Typical Slab to Slab Connection Detail. 


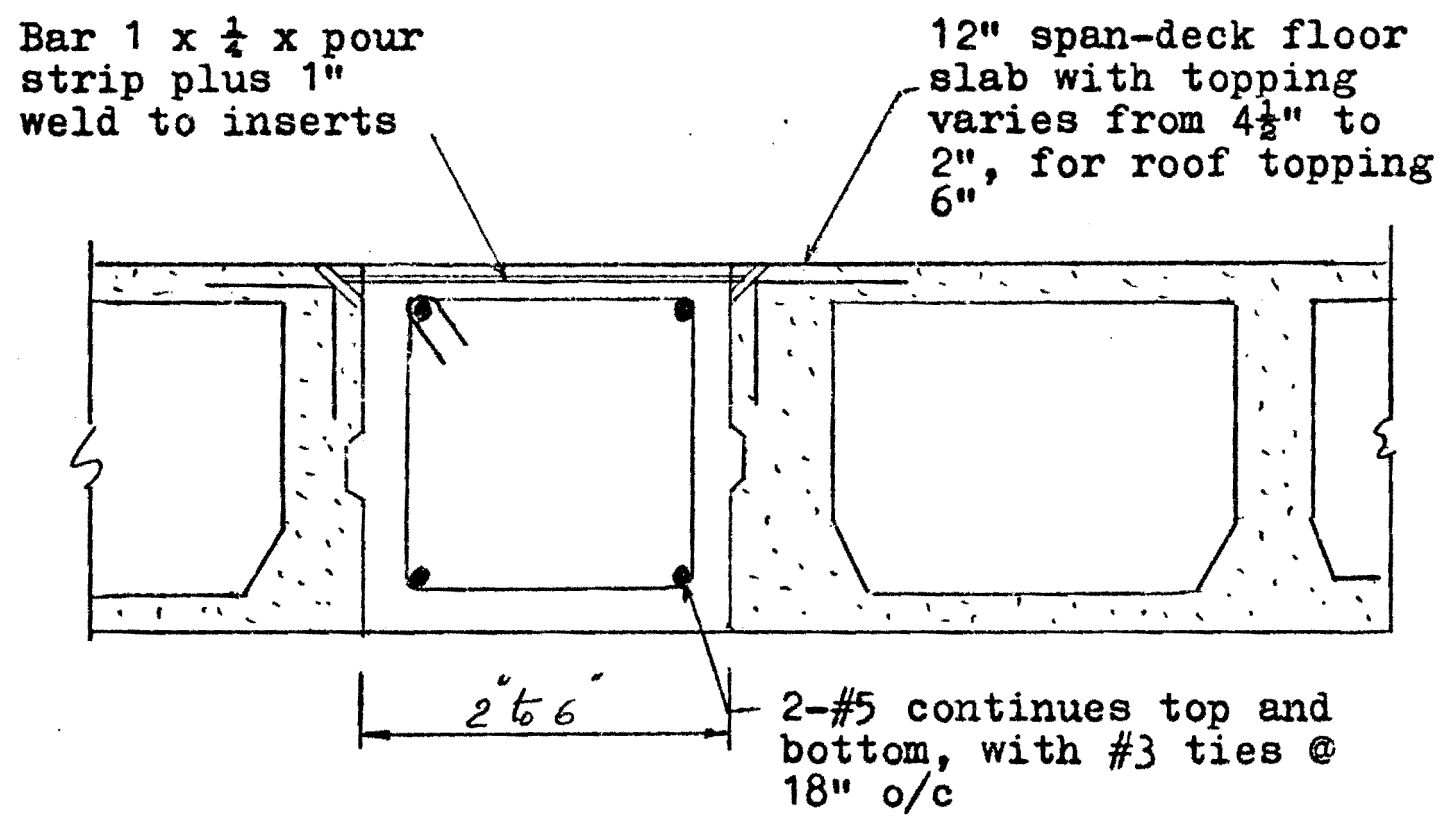

Figure 3.73. Cast-in-Place Covering of Opening Between Two Slabs. 
In the case of rising prices, the cost per car compares well with several other sizable garages built in recent years by different methods. A steel frame garage built in New Bedford, Mass., in 1961, cost $\$ 1,700$ per car; castin-place concrete structures built in Topeka, Kansas in 1961, New Haven, Conn. in 1962, Kansas City, Mo. in 1962 and Boston, Mass. in 1964, range in cost from $\$ 1,600$ to $\$ 3,400$ per car.

According to J. Gerald Phelan, president of Fletcher Thompson, speed and economy were achieved at the Bridgeport" job by simplicity of design, and almost exclusive use of standardized precast concrete structural units. These units consist mainly of 984 prestressed single-Tee beams, 33 in. deep, with $9 \mathrm{ft}$. flanges and 322 columns averaging $75 \mathrm{ft}$. in height. Long spans of the rees ( $60 \mathrm{ft}$. ) reduced the number of columns, and, therefore, the total area required. It has been estimated that using cast-in-place concrete would have increased the size of the garage by $10 \%$ to 15\% without additional parking area.

The decks in one bay are level. In the other, the decks slope upward from one end on a $4 \%$ grade for about two-thirds of the length of the building for entering, and downward on a $6 \%$ grade for the remaining length for exitinf. 


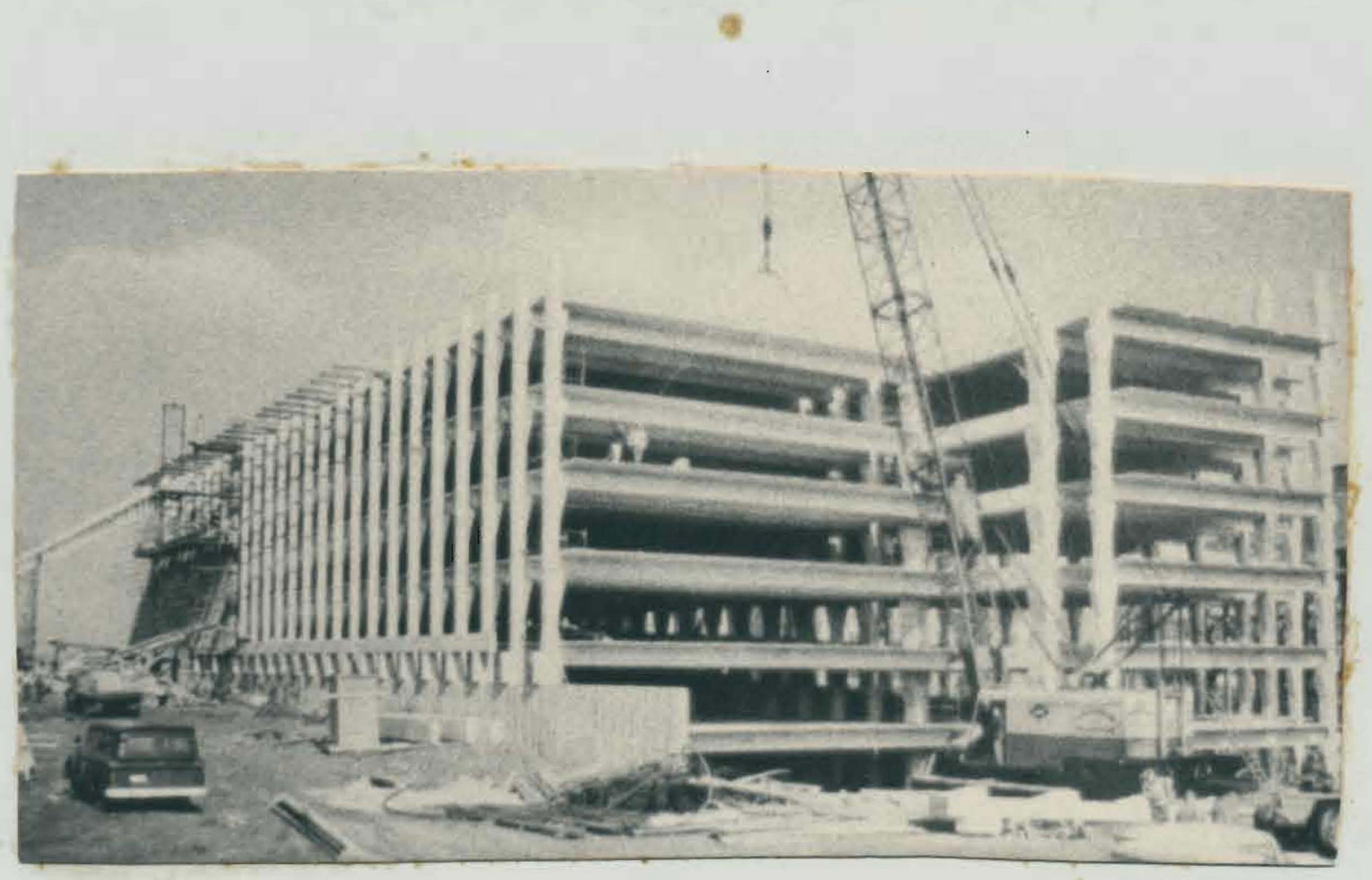

Figure 3.74. General View of Bxidgeport Garage in 
CHAPTER IV

\section{USE OF PRECAST CONCRETE}

UNITS FOR BUILDINGS

IN IRAN

\subsection{GEOGRAFHY}

Iran is a part of the Iran plateau which consists of Iran, Afghanistan, and Pakistan, as shown in Fig. 4.1. It is situated in the North temperate zone, which is between 44 degrees and 63 degrees longitude and 25 degrees and 40 degrees latitude. ${ }^{22}$ It has an area of 628,000 square miles $(1,645,000 \mathrm{sq} . \mathrm{km}$.$) and a population of 30,329,000$, of which $43 \%$ is urban population and $57 \%$ is rural population. 22 The net rate of popuiation growth in Iran has been about 600,000 a year since 1956, or about 18 persons per square kilometer. In comparison to the United States or Europe, Iran's area is equal to the total areas of Texas, New Mexico, Arizona and California, in the United States, and is equal to the total areas of England, France, Germany, Italy, Belgium, Holland and Denmark, in Europe.

Iran has a varied geographical, geological and climate composition. For example, one can be certain of reaching water by drilling a shallow well in the Caspian Sea area in the north of Iran, but no deep wells have reached water in the central parts of Iran, such as Hamadan and Kermanshah 
(See Fig. 4.1).22 These differences are due to the history of the Iran Plateau, which was a sea bed in the pre-historic era. 


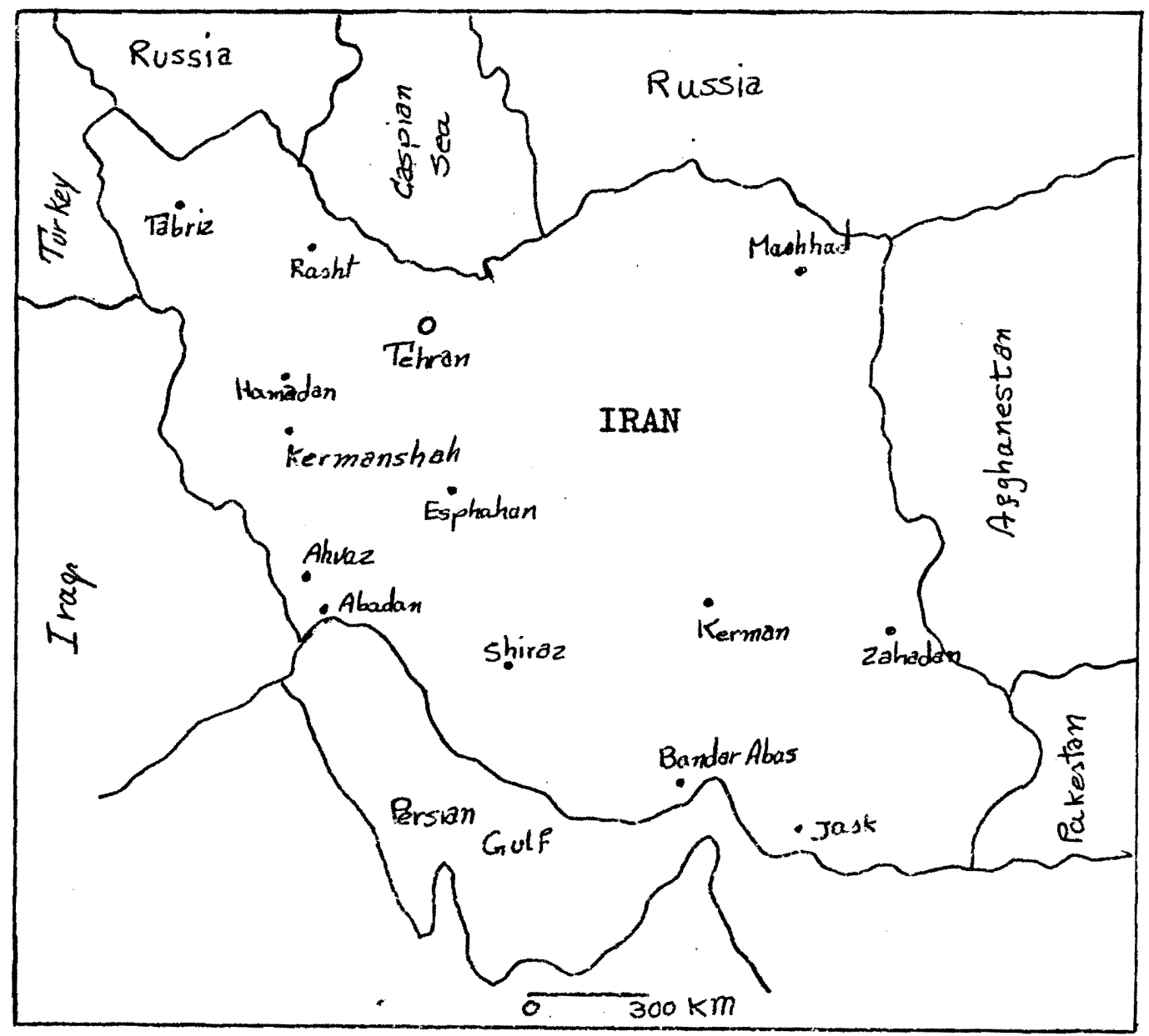

Figure 4.1. Map of Persia (Iran) and its Neighbors. 


\subsection{CLIMATE}

The climate of Iran is different in various regions. Iran is a mountainous country. The two major mountain systems are the Alborz in the north, which is almost a continuous range from the Turkish frontier in the northwest to the Afghanistan border in the northeast, and the Zagros Chains, which extend from the northwest to the southeast of the country. The highest peak in Iran is the volcanic cone of Damavand, with an elevation of 5,671 meters $(18,940 \mathrm{ft}$.$) .$ The lowest plains lie along the Caspian Sea at about -22 meters ( $-73 \mathrm{ft.}$ ) below sea level. There are two narrow lowlands in the country, one separating the northerm slopes of the Alborz from the Caspian Sea, and the other, more extensive in area, separating the westem and southem foothills of the Zagros and its associate mountains. The remaining lands are, in the central and easterm parts of the country, comprised of roughly one-third of the total area of Iran, and are occupied by flat or sand deserts. 22

The great differences in elevation in Iran result in varied climatic conditions, which range from cold over high levels to hot at lower altitudes in the south. The highland areas have cold winters and mild summers. The average minimum January temperatures for the highlands have been recorded to be $-12^{\circ} \mathrm{C}\left(10^{\circ} \mathrm{F}\right)$, with the lowest temperature at 
$-36 \mathrm{C}(-64 \mathrm{~F})$ at the Alborz ranges. The maximum summer temperature in the highlands is about $36^{\circ} \mathrm{C}\left(86^{\circ} \mathrm{F}\right)$, and drops to around $10^{\circ} \mathrm{C}\left(50^{\circ} \mathrm{F}\right)$ at night.

The lowlands, with the exception of the Caspian Sea area, are characterized by dry weather, with temperatures varying from $0^{\circ} \mathrm{C}\left(32^{\circ} \mathrm{F}\right)$ to $55 \mathrm{C}\left(131^{\circ} \mathrm{F}\right)$, during the year. 22 The narrow coast of the Caspian Sea is characterized by moderate temperatures, low daily and annual ranges, excessively high humidity and heavy precipitation. Mean summer temperature in this area is around $26 \mathrm{C}(78 \mathrm{~F})$ and mean winter temperature about $7{ }^{\circ} \mathrm{C}\left(44^{\circ} \mathrm{F}\right)$. The Iranian Meteorological Department released information presented in Table IV.1 on different climatic regions of Iran observed in the period 1952 to 1969. 


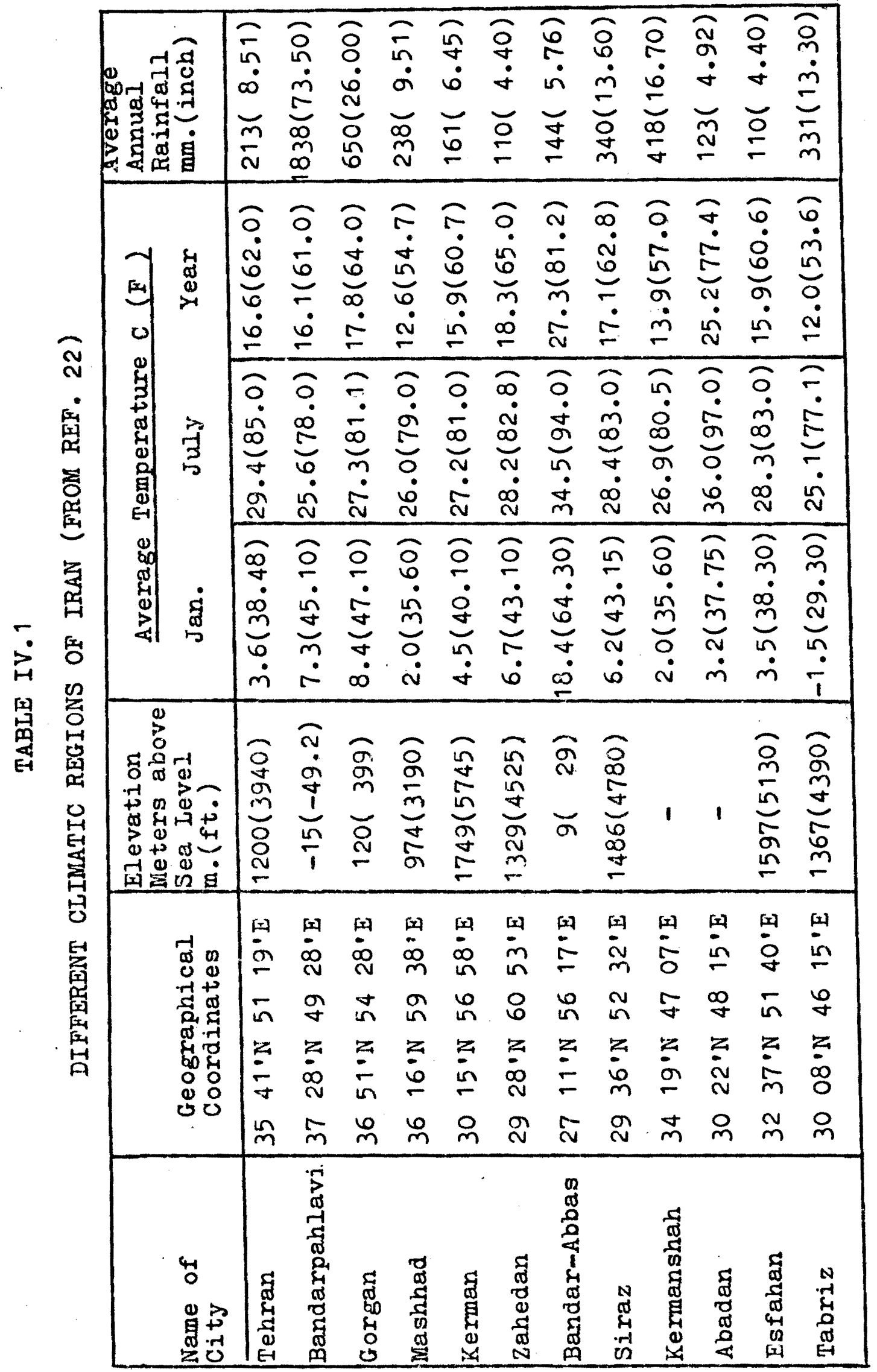




\subsection{EARTHQUAKES}

Some 50,000 people have died in various earthquakes in Iran during the pasttwelve years alone. ${ }^{22}$ Earthquakes have struck various parts of Iran, but tine largest number of earthquakes have been in Farse in the south; Khorassan in the northeast; and Qazvin not far from Tehran in the central region. The nost deadly earthquakes in Iran during the past twelve years were: the Lar (close to Shiraz) earthquake in 1960, which led to the complete destruction of Iar and twenty other villages. The number of dead was estimated at over 12,000; the Qazvin Plain earthquake in 1962, which killed 12,400 people; the Khorassan earthquake in 1968, which claimed some 20,000 lives and injured 50,000; and the latest on April 10, 1972, around Lar, which claimed 4,000 lives. The magnitude of this earthquake was 9.5 on the Richter scale. The effects were felt within a radius of 400 kilometers. Fig. 4.2 shows the major earthquakes in Iran. 22 


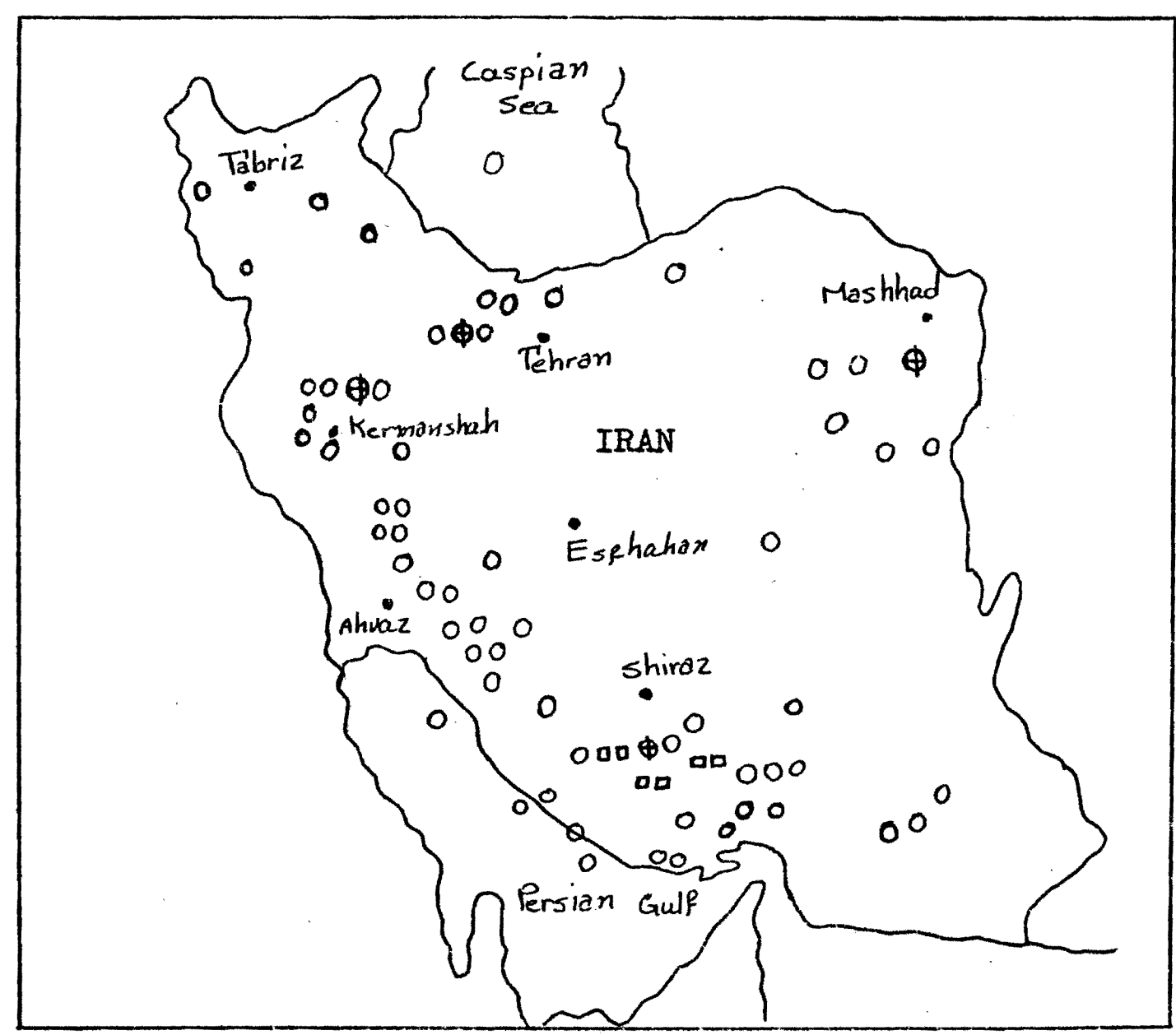

Earthguake

$\phi$

0
Intensities

$\geqslant .0-0$ Richter
$5.0-6.9$ Richter
5.9 Richter

Figure 4.2. Major Earthquakes in Iran. 


\subsection{STEEL PRODUCTION}

The metallurgical industry in Iran is rapidly growing. Aryamehr, the first steel mill in Iran, was started in 1965 , in the Esfahan area. The Arymehr Steel Mill, with an original capital of $49,150,000,000$ rials $(\$ 1.00 \cong 75$ rials), started production in early 1972, with the first output of pig iron in the country. ${ }^{22}$ In the first year of production, it was expectea to give an output of 630 tons of pig iron, structural steels and reinforcement bars. It is estimated that this output will grow to $1,900,000$ tons (one ton $=$ 2,204 Ibs.) by 1977-78, and to 4,000,000 tons ten years later. It is expected that this steel mill will produce all structural steels, rails and sheet iron required by the country. Intermal consumption of iron has risen during the last few years to 800,000 tons, and during this time, imported iron constituted $14.3 \%$ of Iran's total imports. The price of steel produced by the Aryamehr Steel Mills will be on international levels or may be even lower. 


\subsection{CEMENT PRODUCTION}

Production of cement in 1971-72 amounted to about 3,000,000 tons, produced by eleven major mills, five of which are located around Tehran, the capital. 22 Ministry of Economy officials believed that with the completion of the cement mills, the country would no longer need foreign cement by 1972-73. The home industry will be able to meet the entire national requirement until 1978.

Five major mills, Tehran, Abyck, Mashhad, Kerman and Esfahan Cement Mill were expected to expand their capacities to about 10,000 tons (total) by 1973 .

By 1974, the Sufian and Fars mills will raise production to 1,000 tons a day, and Aryamehr Cement Mill will also start production with the same capacity and by the same time. The Aryamehr nill is being jointly constructed at Esfahan by the Steel Corporation and the Army Ordinance. The daily capacity of the mill would be 5,000 tons, which would be the largest cement mill in Iran.

In 1970-71, cement production in the country amounted to about 2.75 million tons, whereas consumption was about 2.99 million tons. By $1972-73$, production was expected to rise to 3.44 million tons, and by January 1973, it was expected to rise to 3.7 million tons. At the current rate, consumption will amount to only 3.435 million tons. The 
overhead balance will be exported to neighboring countries. 


\subsection{HOUSING SHORTAGES IN IRAN}

In May 1971, the Urban Developement and Housing section of the Plan Organization submitted a report on the results of the last three years of their activity, which expressed dissatisfaction with the lack of progress of urban development and housing, and called for a "basic review" of the situation.

Construction and completion of various urban installation projections, which had a total budget of $16,000 \mathrm{mil}-$ lion rials ( $\$ 21$ million), had slowed down in those three years due to various difficulties; one of which was lack of proper criteria necessary to help in the select on of projects and determination of their priorities. For instance, in many towns where there is no water supply system, funds have been allocated to such secondary projects as building of abbatments for power lines and street paving.

According to the statistics released by the Central Bank of Iran, urban population can be divided into the following five categories. 22

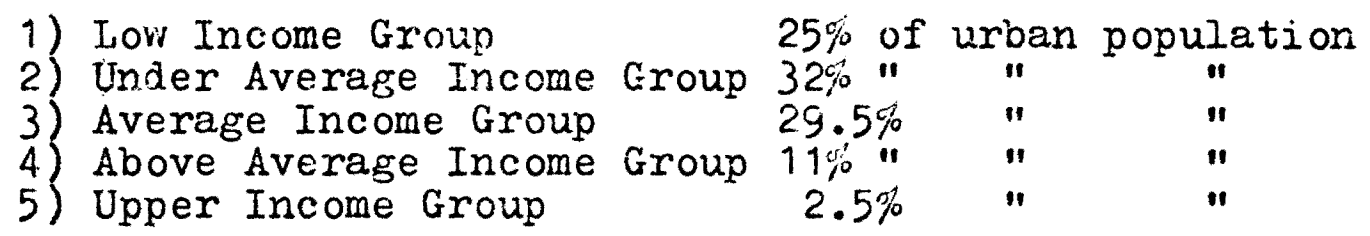
According to a report by the Minister of Housing and Development in $1971,33 \%$ of the urban population lived in 
houses taken on a rental basis. This ratio is higher than most of the developed countries of the vorld.

In 1966, there were 133 housing units for every 1,000 persons, while in 1971, there were only 127. However, conditions improved somewhat in 1971-72, when municipalities lifted a number of restrictions on housing permits which had been imposed by implementations of the newly passed 'Renovation Laws'. In the first nine months of this year, this resulted in the issue of 10,704 housing permits in the city of Tehran alone (i.e., 20.9\% more than the previous years), and, similarly, a 13.8\% increase in other large cities.

It has been said that the current rise in the rental value is due to population growth in urban areas, dissatisfaction in the housing programs, unprecedented rise in the prices of plots of land within city limits, and price rises in construction materials and building costs. These factors have controlled higher rents so much that, as compared witr. 1965-66, rents have risen 56\% in 1970-71, and the cost of land has risen $130 \%$. It can thus be seen that in such cases, it is almost impossible for a person of low income to own a house because a large part of his income is devoured by the high rents.

Urgent steps taken by govermment to meet the situation are as follows: 22

1) Campaign against land speculation.

2) Government and construction companies plans 
for housing.

3) Reduction in the interest on housing loans and further facilitating terms of housing loans.

4) Amendments to the law of lessor and lessee.

5) Land price controls in 1971-72.

According to the plans prepared by the experts of the Ministry of Development and Housing, about 1.8 million housing units should be built during the period 1972-82, and that at present the country is short of 400,000 housing units. Government has estimated that 549 billion rials are needed to implement this plan. Adding to the amount to be invested by the private sector, the total required will be about 960 billion rials. 


\subsection{LOW COST HOUSING}

As mentioned in section 4.6, the housing shortage is one of the major problems in Iran. The main reasons for the severity of this problem at present are population increase and rapid urbanization. Also, the cost of land and housing, as compared to the limited financial resources of the community remains very high. The major factors in housing costs in urbar areas are the cost of land, materials, and labor. The cost of labor in Iran is much less than the cost of land and materials. ${ }^{22}$ In some developed countries, the situation is just the reverse. Economy in the construction of low cost housing can be achieved by proper layout, proper selection of materials, better structural design and economical construction techniques.

In addition to the above considerations, sociological problems should also be considered for effective means of urban renewal for people of low income. The new developments should be comprised of a comples center close to mass transportation, with large areas of green. 11

The lack of housing in developing countries is partially aue to the poor economic condition of the individual, which makes it difficult for him to contribute to the cost of his housing. The only way to counteract this problem is for local officials to plan and design large housing pro- 
jects, and divide the total cost on a sector level in order to increase productivity and decrease cost of construction. For example, consider the country of Turkey, which has similar housing problems. An extensive study by D. Sorgu illustrates that in Turkey, construction by means of prefabricated components is about $9 \%$ cheaper than the conventional methods. ${ }^{11}$ In this study, the inajor variables considered in mathematical modeling were materials, land price, prefabrication forms cost and labor cost.

Similar studies have been carried out in most European and Asian countries, and also in the United States. 11 Assembling housing by prefabricated members was generally recommended by all the investigators at the International Symposiums on Low Cost Housing Problems related to Urban Renewal and Development hela at the University of Missouri at Rolla in October 1971. 11

In Iran, since concrete and steel reinforcement are expected to be produced in excess of the country's needs, buildings predominantly constructed with precast concrete members appear to be a logical alternative for partial solution to the housing problem.

Precast concrete members can be used for small, single level housing units in rural areas, since land cost is not high. They are also desirable for high rise buildings in urban areas, where land cost is one of the primary considerations in the total cost. 
As discussed in Section 4.2, earthquakes constitute a major natural force to be considered in design, which causes the need for stronger building materials for more permanent and structurally dependable housing. Since the country does not have a supply of wood for construction, steel and concrete would be the two major materials to be used. Today, in rural areas, less expensive houses are built primarily with unreinforced brick and mud. It is obvious that these types of building comporents are not strong enough to withstand the variations in climate from extreme heat to excessive rain and snow, as discussed in Section 4.1, and, these structures do not have the proper resistance to withstand trie earthquake load. Concrete with proper shear design would be the ideal material to use, especially in the areas with stronger and more frequent earthquakes. 


\subsection{SIX NIAJOR PRECAST \\ CONCPETE PLANTS}

\section{IN IRAN}

Knowing the quality of concrete as a structural material and the problem of the housing shortage in Iran, tinis author studied the availability of precast concrete manufacturing plants in Iran. A questionnaire was formulated and sent to twelve precasting plants in Iran. Six of these questionnaires were completed and returned. The results of the answers are summarized in Table 4.2.

Information obtained from the questionnaires indicates that there are at least twelve precast prestressed concrete plants, all located in Tehran (capital of Iran). These plants produce different sizes of structural units for buildings. Precast prestressed concrete members produced by these plants are slabs, beams, wall paneis and bearing walls.

The strength of matexials used in prestressed concrete members are: steel, with ultimate strength of up to $255 \mathrm{Ksi}$; and conerete, with an ultimate strength of up to 8,500 Psi. The strengths are comparable to those used in the United. States. Simple connections which are generally used by these plants are dowels, studs or bolts and reinforcing bars, lapped or welded.

A list of all buildings winich have been built recently using precast prestressed concrete members was ob- 
tained from the questionnaires, and is presented in Table 4.3. The illustrative photographs showing some of these buildings, which were obtained by the author, are presented in Figs. 4.3 through 4.9. The total area under construction for the nine buildings listed in Table IV. 3 is $156,000 \mathrm{~m}^{2}\left(1,700,000 \mathrm{ft}^{2}\right)$. 
TABLE IV. 2

INFORMATION OBTAINED FROM SIX

PRECAST COINCRETE PLANTS

\begin{tabular}{|c|c|c|c|c|}
\hline No. & $\begin{array}{l}\text { Name of } \\
\text { Engineer }\end{array}$ & Position & $\begin{array}{l}\text { Address of } \\
\text { Engineering } \\
\text { Firm }\end{array}$ & $\begin{array}{l}\text { Name \& location } \\
\text { of prestressing } \\
\text { plants known to } \\
\text { engineering } \\
\text { firm(combined } \\
\text { list) }\end{array}$ \\
\hline I & $\begin{array}{l}\text { Hormoz- } \\
\text { Maleki }\end{array}$ & $\begin{array}{l}\text { Chief } \\
\text { Engineer } \\
\text { (C.E.) }\end{array}$ & $\begin{array}{l}\text { Ave. No. } 8 \\
\text { Vozara Ave. } \\
\text { Tehran, Iran }\end{array}$ & \multirow{6}{*}{$\begin{array}{l}\text { 1) Parniab } \\
\text { Tehran, Iran } \\
\text { 2) Sock Beton } \\
\text { Tehran, Iran } \\
\text { 3) Eshpan Beton } \\
\text { Tehran, Iran } \\
\text { 4) Dima } \\
\text { Karaj, Iran } \\
\text { 5) Beton Batiman } \\
\text { Tehran, Iran } \\
\text { 6) Sab Co. } \\
\text { Tehran, Iran } \\
\text { 7) Italran } \\
\text { Tehran, Iran } \\
\text { 8) Perfab Co. } \\
\text { Tehran, Iran } \\
\text { 9) Perican Co. } \\
\text { Tehran, Iran } \\
\text { 10) Beton Hak Co. } \\
\text { Tehran, Iran } \\
\text { 11) Estop Co. } \\
\text { Tehran, Iran } \\
\text { 12) Prebeton Co. } \\
\text { Tehran, Iran }\end{array}$} \\
\hline II & $\begin{array}{l}\text { Zareh } \\
\text { Petrosian }\end{array}$ & $\begin{array}{l}\text { Chief } \\
\text { Engineer } \\
\text { (C.E.) }\end{array}$ & $\begin{array}{l}\text { Sab Co., No. } \\
20 \text {, Bozargo- } \\
\text { mehr Ave. } \\
\text { Tehran, Iran }\end{array}$ & \\
\hline III & $\begin{array}{l}\text { Abbas } \\
\text { Amir- } \\
\text { Teimoor }\end{array}$ & $\begin{array}{l}\text { Chief } \\
\text { Engineer } \\
\left(C . \text {. }_{\text {. }}\right)\end{array}$ & $\begin{array}{l}\text { Polytecknic } \\
\text { College } \\
\text { Tehran, Iran }\end{array}$ & \\
\hline IV & $\begin{array}{l}\text { Mr. } \\
\text { Serkesian }\end{array}$ & $\begin{array}{l}\text { Chief } \\
\text { Engineer } \\
(\mathrm{C.E.})\end{array}$ & Tehran, Iran & \\
\hline V & $\begin{array}{l}\text { Farhad } \\
\text { Manmoodi }\end{array}$ & $\begin{array}{l}\text { Crief } \\
\text { Ensineer } \\
\text { (C.E.) }\end{array}$ & $\begin{array}{l}\text { No. } 60, \text { For } \\
\text { sat Ave. } \\
\text { Shahreza, } \\
\text { Tehran, Iran }\end{array}$ & \\
\hline VI & $\begin{array}{l}\text { Name } \\
\text { Unsigned }\end{array}$ & $\begin{array}{l}\text { Chief } \\
\text { Engineer } \\
\text { (C.E.) }\end{array}$ & $\begin{array}{l}\text { Prebeton Co. } \\
\text { of Iran, No. } \\
82 \text { Panlavi } \\
\text { Ave., Tehran } \\
\text { Iran }\end{array}$ & \\
\hline
\end{tabular}


TABLE IV.2

CONTINUATION

\begin{tabular}{|c|c|c|c|}
\hline No. & $\begin{array}{l}\text { Kind of units } \\
\text { produced by the } \\
\text { plants (beam, } \\
\text { girder, slab, } \\
\text { wall panel, } \\
\text { column, etc.) }\end{array}$ & $\begin{array}{l}\text { Strength of } \\
\text { concrete used in } \\
\text { prestressing, } f_{c}^{\prime} \\
\mathrm{Kg} / \mathrm{Cm}^{2} \text { (Psi) }\end{array}$ & $\begin{array}{l}\text { Strength of } \\
\text { prestressing } \\
\text { steel - } \mathrm{f}_{\mathrm{y}} \\
\mathrm{Kg} / \mathrm{Cm}^{2}(\mathrm{Ksi})\end{array}$ \\
\hline$I$ & $\begin{array}{l}\text { slab, beam, } \\
\text { wall panel, } \\
\text { column, } \\
\text { bearing wall }\end{array}$ & $\begin{array}{l}\text { 1) } 400 \mathrm{Kg} / \mathrm{cm}^{2} \\
(\simeq 5,750 \text { Psi) } \\
\text { in wall parels } \\
\text { 2) } 600 \mathrm{Kg} / \mathrm{cm}^{2} \\
(\simeq 8,750 \text { Psi) } \\
\text { in slabs }\end{array}$ & - \\
\hline II & $\begin{array}{l}\text { slab, beam, } \\
\text { bearing wail, } \\
\text { wall panels }\end{array}$ & - & - \\
\hline III & $\begin{array}{l}\text { slab, beam, } \\
\text { wall panel, } \\
\text { bearing wail }\end{array}$ & $\begin{array}{l}\text { 1) } 550 \mathrm{Kg} / \mathrm{Cm}^{2} \\
(\simeq 8,000 \mathrm{Psi})\end{array}$ & - \\
\hline IV & $\begin{array}{l}\text { beam, girder, } \\
\text { wall panel, } \\
\text { slab, bearing } \\
\text { wall }\end{array}$ & - & - \\
\hline $\mathrm{V}$ & $\begin{array}{l}\text { beam, slab, } \\
\text { girder, wail } \\
\text { panel, bearing } \\
\text { wall, column }\end{array}$ & $\begin{array}{l}350-400 \mathrm{KG} / \mathrm{cm}^{2} \\
(5,000-5,750 \\
\mathrm{PSI})\end{array}$ & $\begin{array}{l}\text { 1)yield point } \\
140 \text { to } 160 \\
\mathrm{Kg} / \mathrm{mm}^{2} \\
(\simeq 200 \text { to } 230 \\
\text { Ksi) } \\
\text { 2)rupture } \\
160 \text { to } 180 \\
\mathrm{Kg} / \mathrm{mm}^{2} \\
(\approx 230 \text { to } 255 \\
\mathrm{Ksi})\end{array}$ \\
\hline$\overline{\text { VI }}$ & $\begin{array}{l}\text { beam, sleb, } \\
\text { girder, wall } \\
\text { panel, bearing } \\
\text { wall }\end{array}$ & $\begin{array}{l}500-600 \mathrm{KG} / \mathrm{Cm}^{2} \\
(7,000-8,570 \\
\text { Psi) }\end{array}$ & - \\
\hline
\end{tabular}


TABIE IV. 2

CONTINUATION

\begin{tabular}{|c|c|c|c|}
\hline No. & $\begin{array}{l}\text { Weight of the } \\
\text { largest unit } \\
\text { produced } \\
\text { Kg(Kips) }\end{array}$ & $\begin{array}{l}\text { Methods of } \\
\text { connection of } \\
\text { units }\end{array}$ & $\begin{array}{l}\text { Cost/unit area } \\
\text { Rials/m } \\
\left(\begin{array}{l}\left.\text { t }^{2} / \mathrm{f}^{2}\right) \\
\text { for members }\end{array}\right. \\
\end{array}$ \\
\hline$I$ & $\begin{array}{l}6,000 \mathrm{Kg} \\
(13.2)\end{array}$ & $\begin{array}{l}\text { Using anchorage \& } \\
\text { grouting. Connect- } \\
\text { ion with steel bars, } \\
\text { welding anchor bojts } \\
\text { or screws. }\end{array}$ & - \\
\hline II & - & $\begin{array}{l}\text { Welding \& bolts } \\
\text { \& screws. }\end{array}$ & $\begin{array}{l}400-800 \text { Rials/ } \\
\mathrm{m}^{2}(\$ .6 / \mathrm{ft} 2 \text { to } \\
\$ 1.2 / \mathrm{ft} 2) \\
\text { Production: } \\
300,000 \mathrm{~m} 2 / \\
\text { year }(3.24 \mathrm{x} \\
106 \mathrm{ft} / \text { year) }\end{array}$ \\
\hline III & $\begin{array}{l}20,000 \mathrm{Kg} \\
(44.2) \\
5,000 \mathrm{Kg} \\
(11.05)\end{array}$ & $\begin{array}{l}\text { According to Amer- } \\
\text { ican \& European } \\
\text { standards. Connect- } \\
\text { ed like drawers. } \\
\text { Small beams are } \\
\text { connected to large } \\
\text { ones by weloing. }\end{array}$ & \\
\hline IV & - & - & $\begin{array}{l}500-600 \text { Rials } \\
\mathrm{m}^{2}\left(\$ .75 / \mathrm{ft}^{2}\right. \\
\left.\text { to } \$ .90 / \mathrm{ft}^{2}\right) \\
\text { building cost/ } \\
\mathrm{m}^{2} \text { is } 2500 \\
\text { Rials } / \mathrm{m}^{2}(\$ 3.8 \\
\left./ \mathrm{ft}^{2}\right)\end{array}$ \\
\hline V & $\begin{array}{l}6,000- \\
10,000 \mathrm{Kg} \\
(13.2 \rightarrow 22.1) \\
10,000- \\
15,000 \mathrm{Kg} \\
(22.1-33.2)\end{array}$ & $\begin{array}{l}\text { Connection of pre- } \\
\text { imbedded bars in } \\
\text { units \& pouring } \\
\text { concrete to create } \\
\text { unity. }\end{array}$ & $\begin{array}{l}\text { building cost } \\
\mathrm{m}^{2} \text { is } 555 \mathrm{Rial} \\
/ \mathrm{m}^{2}\left(\$ .85 / \mathrm{ft}^{2}\right)\end{array}$ \\
\hline VI & - & $\begin{array}{l}\text { Connected to col- } \\
\text { umns \& anchor } \\
\text { beams. }\end{array}$ & - \\
\hline
\end{tabular}


TABLE IV. 3

PARTIAL IIST OF BUILDINGS WHICH HAVE BEEN BUILT IN IRAN USING PRECAST PRESTRESSED CONCRETE MEMBERS (COMPILED FROM QUESTIONAIRES)

\begin{tabular}{|c|c|c|c|c|}
\hline No. & $\begin{array}{l}\text { Name of Building } \\
\text { and Address }\end{array}$ & $\begin{array}{l}\text { Name of } \\
\text { Contractor }\end{array}$ & $\begin{array}{l}\text { Crief } \\
\text { Engineer }\end{array}$ & $\begin{array}{l}\text { Area Under } \\
\text { Construction } \\
\text { meter }{ }^{2}\left(f t^{2}\right)\end{array}$ \\
\hline $\mathbb{I}$ & $\begin{array}{l}\text { Iran Natl, Bank } \\
\text { Shahreza Ave. } \\
\text { Tehran, Iran }\end{array}$ & Teza & $\begin{array}{l}\text { Kampes- } \\
\text { aks }\end{array}$ & $\left(1,200 \mathrm{~m}^{2} \mathrm{f}^{2}\right)$ \\
\hline II & $\begin{array}{l}\text { Mashad Tram } \\
\text { Station } \\
\text { Mashad, Iran }\end{array}$ & $\begin{array}{l}\text { Saman } \\
\text { Tishan }\end{array}$ & - & $\begin{array}{l}5,800 \mathrm{r}^{2} \\
\left(62,500 \mathrm{ft} \mathrm{t}^{2}\right)\end{array}$ \\
\hline III & $\begin{array}{l}\text { Agricultural } \\
\text { Department } \\
\text { Ilzabet Blvd. } \\
\text { Tehran, Iran }\end{array}$ & Third & $\begin{array}{l}\text { Farmar: } \\
\text { Farmayan }\end{array}$ & $\begin{array}{l}33,000 \mathrm{~m}^{2} \\
\left(356,000 \mathrm{ft} \mathrm{t}^{2}\right)\end{array}$ \\
\hline $\mathrm{IV}$ & $\begin{array}{l}\text { Arj Factory } \\
\text { Karaj Road } \\
\text { Tehran, Iran }\end{array}$ & $\begin{array}{l}\text { Iran } \\
\text { Sabeta }\end{array}$ & $\begin{array}{l}\text { Farman } \\
\text { Farmayan }\end{array}$ & $\begin{array}{l}27,000 \mathrm{~m}^{2} \\
\left(291,000 \mathrm{ft}^{2}\right)\end{array}$ \\
\hline V & $\begin{array}{l}\text { Arj Factory } \\
\text { offices } \\
\text { Karaj Road } \\
\text { Tehran, Iran }\end{array}$ & $\begin{array}{l}\text { Iran } \\
\text { Sabeta }\end{array}$ & $\begin{array}{l}\text { Famnan } \\
\text { Parmayan }\end{array}$ & 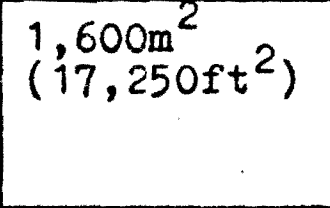 \\
\hline VI & $\begin{array}{l}\text { Politecknic } \\
\text { College Jim- } \\
\text { nezium } \\
\text { Tehran, Iran }\end{array}$ & Baraj & Eatr-Kad & $\begin{array}{l}2,400 \mathrm{~m}^{2} \\
\left(25,900 \mathrm{ft} \mathrm{t}^{2}\right)\end{array}$ \\
\hline VII & $\begin{array}{l}\text { Saman's } \\
\text { Buildings } \\
\text { "ehran, Iran }\end{array}$ & Saman & $\begin{array}{l}\text { Farman } \\
\text { Farmayan }\end{array}$ & $\begin{array}{l}34,000 \mathrm{~m}^{2} \\
\left(366,000 \mathrm{ft} \mathrm{t}^{2}\right)\end{array}$ \\
\hline VIII & $\begin{array}{l}\text { Sepah Square } \\
\text { Tehran, Iran }\end{array}$ & $\begin{array}{l}\text { Hadish- } \\
\text { Rasko }\end{array}$ & $\begin{array}{l}\text { Emak and } \\
\text { Farman } \\
\text { Farmayan }\end{array}$ & $\begin{array}{l}41,000 \mathrm{~m}^{2} \\
\left(443,000 \mathrm{ft}^{2}\right)\end{array}$ \\
\hline $\mathrm{IX}$ & $\begin{array}{l}\text { Different } \\
\text { buildings }\end{array}$ & Teza & - & $\begin{array}{l}10,000 \mathrm{~m}^{2} \\
\left(108,000 \mathrm{ft}^{2}\right)\end{array}$ \\
\hline
\end{tabular}




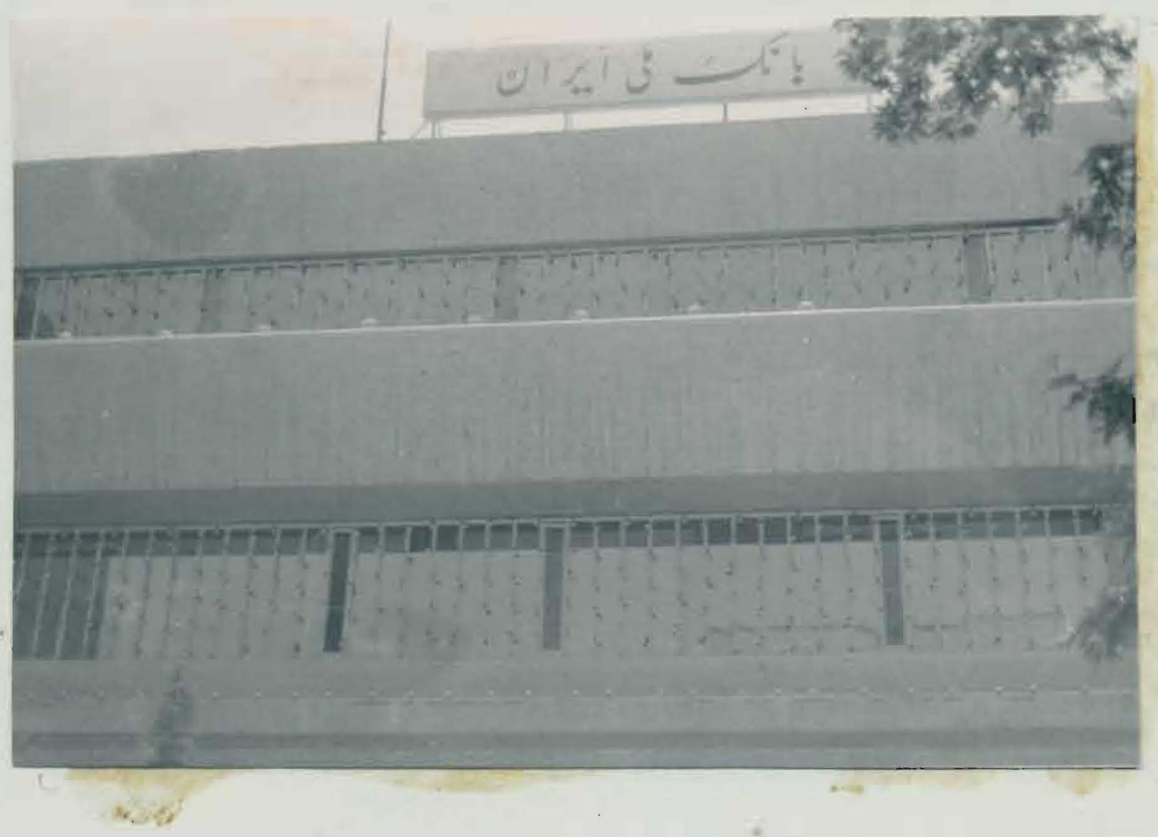

Figure 4.3. Upper Levels of Iran National Bank Building, Shanreza Ave., Tebran, Iran.

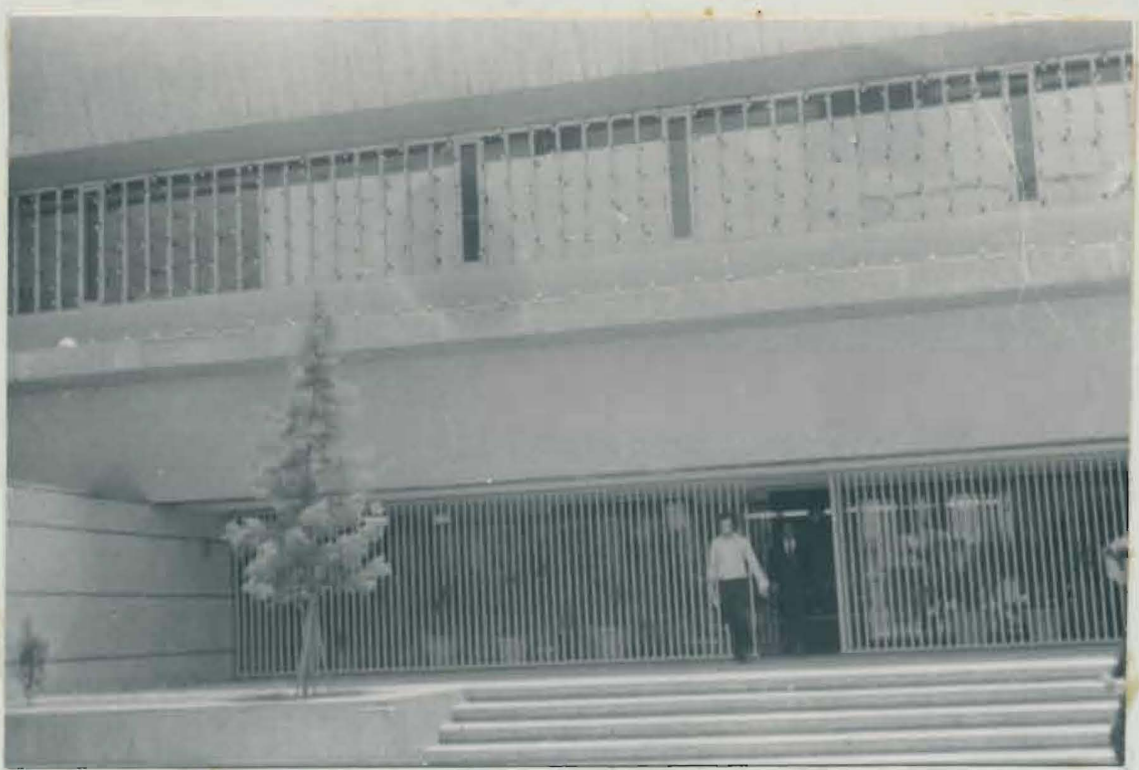

Figure 4.4. ilain Levels of Iran National Bank Building, Shahreze, Ave., Iehran, Iran. 


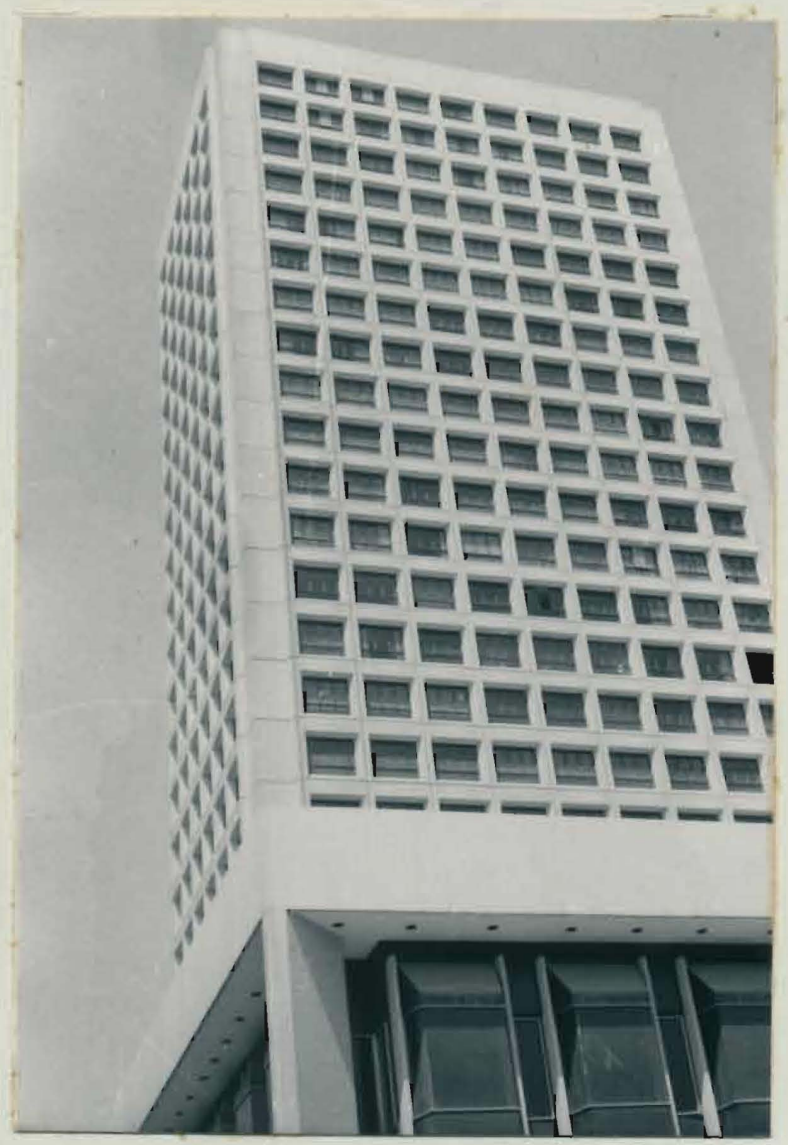

Figuxe 4.5. Saman Builaing, Ilzabet Ave., Tehran, Iran. 


$$
\mathbb{L}
$$




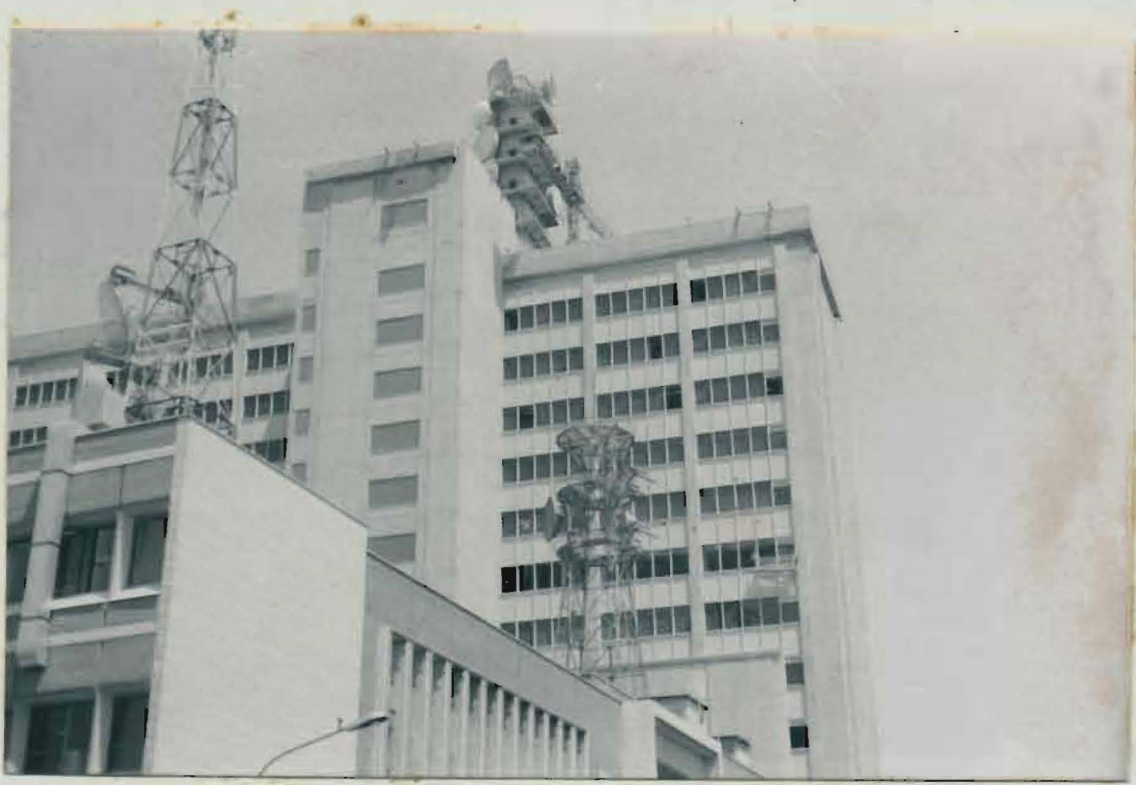

$\frac{\text { Figure 4.7. Front view of Communication Building, Sep- }}{\text { ah Square, Tehran, Iran. }}$

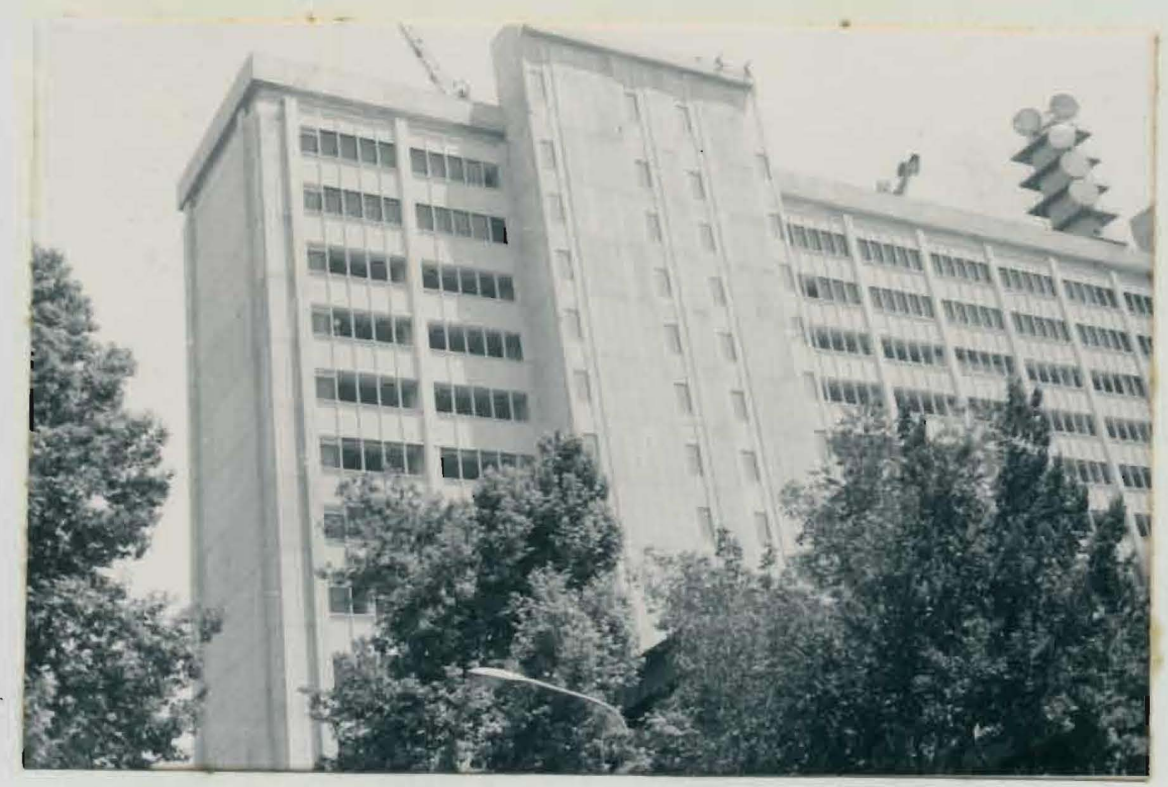

Figure 4.8 . Rear View of Communication Building, Sep-
Qi. Square, Tehran, Iran. 


$$
1
$$




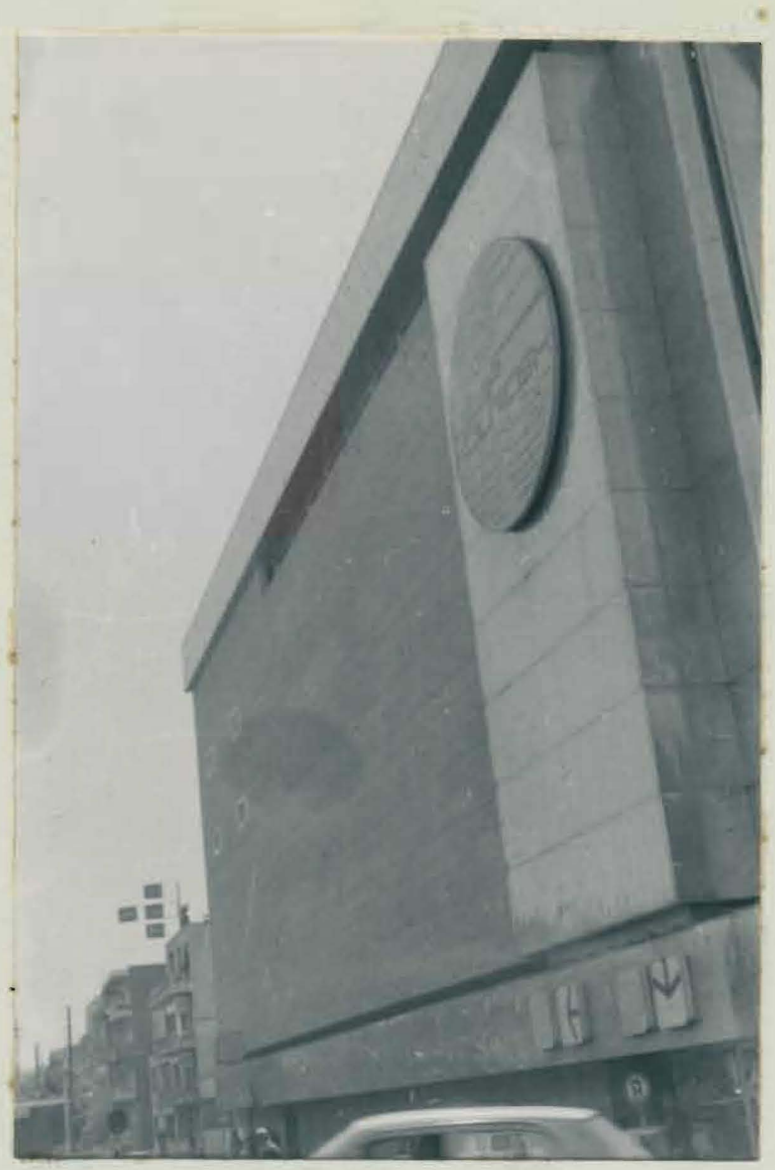

Figure 4.10. Side View of Korosin Department Store, Pahlavi Ave., Tehran, Iran. 


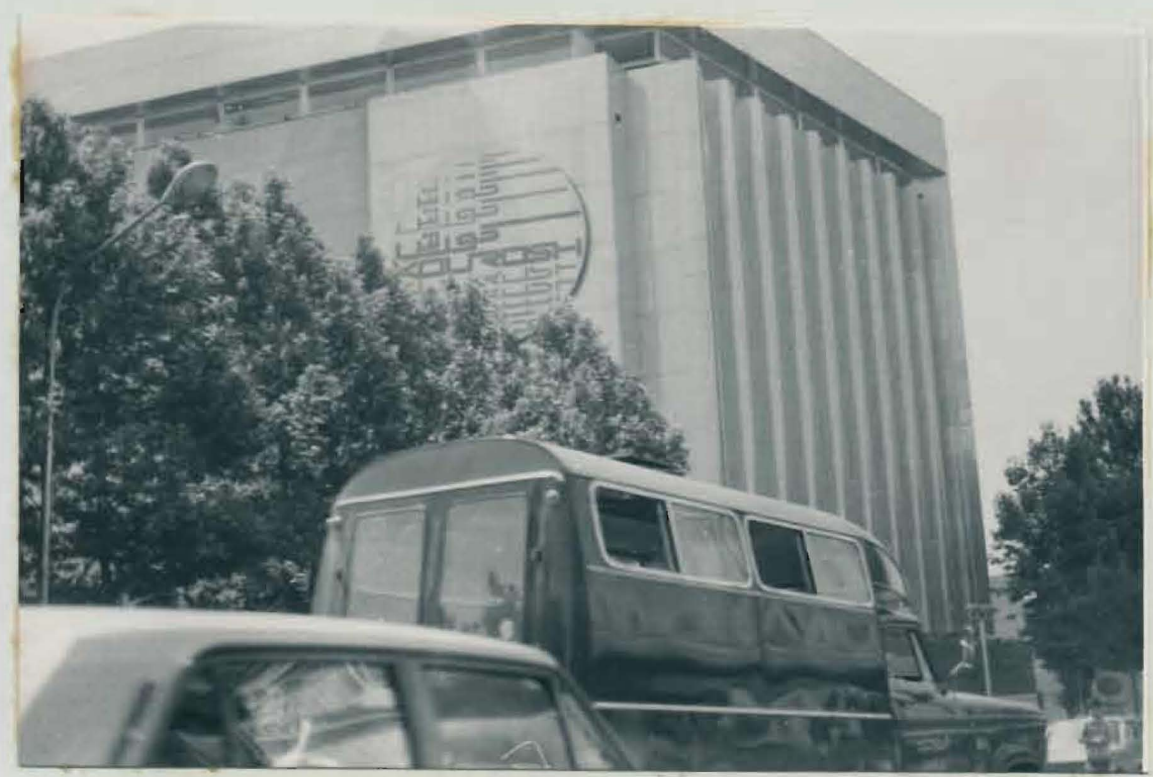
Figure 4.11. Front View of Korosh Department Store,
Pahlavi Ave., Tehran, Iran.

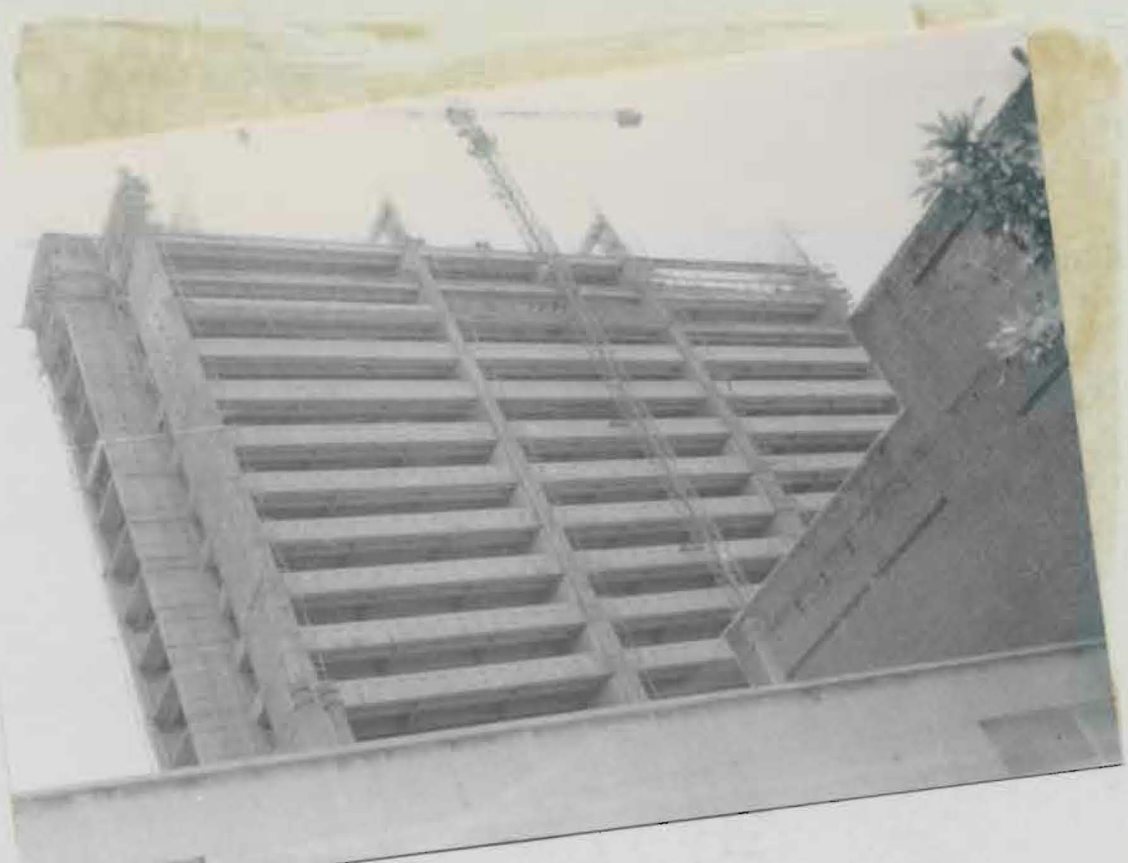
Figure 4.12.
IIzabet Ave., Tehran, Iran. 


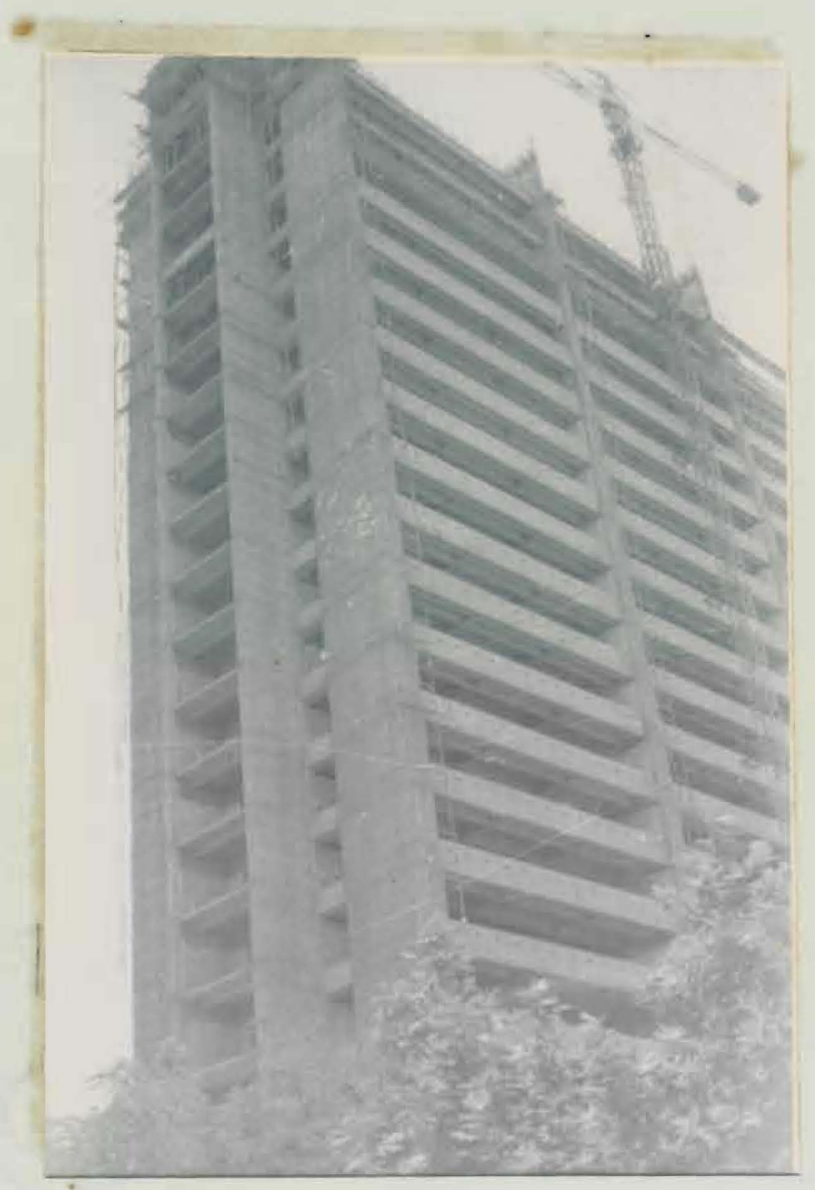

$\frac{\text { Figure } 4.13}{\text { abet Sive, Side View of Agricultural Euilding, Ilz- }}$ 
i) 156

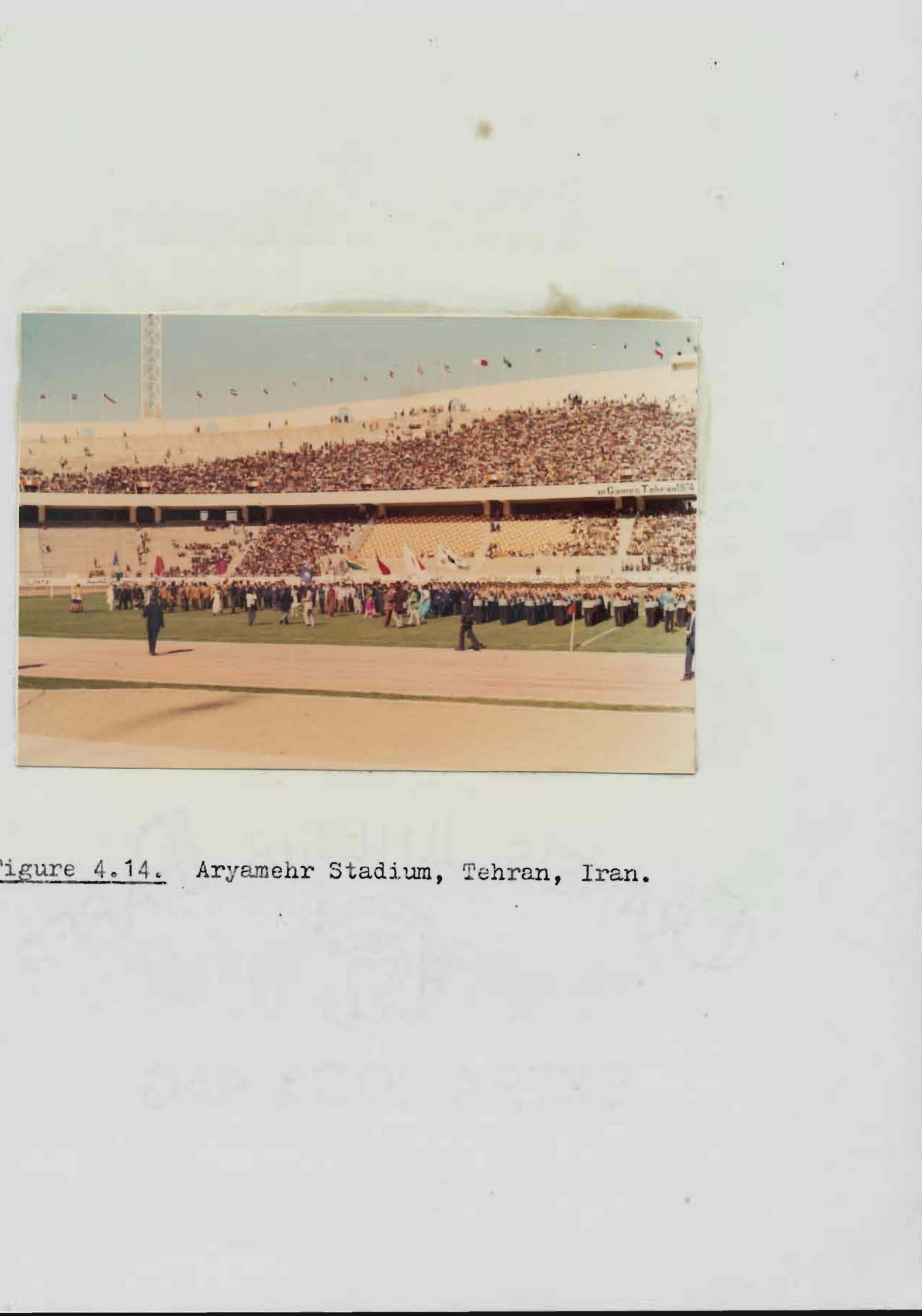

Figure 4.14. Aryamehx Stadium, Tehran, Iran.
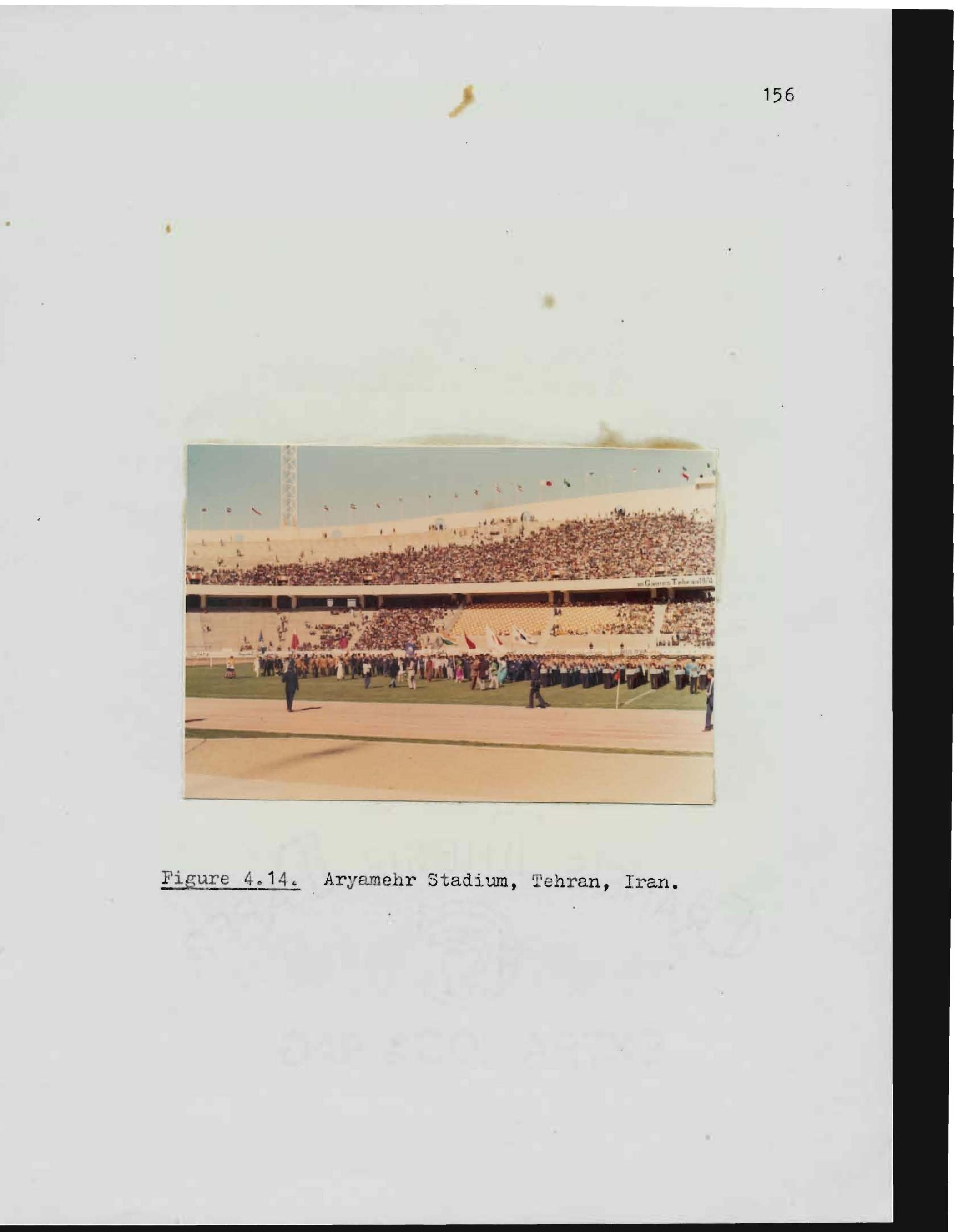

\section{-}

6

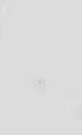

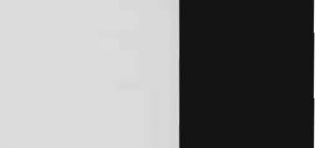




\section{CHAPTER V}

\section{CONCLUSION}

\subsection{UNITED STATES}

From the studies of recent developments in the use of precast concrete members in the United States, and, considering the limited scope of this study, the following observations are made:

1) A vast variety of precast concrete units for buildings are designed and manufactured for different crosssections throughout the United States.

2) The majority of precast concrete units in buildings are assembled together by using simple conneations. These connections usually employ dowels, clip angles, steel plates, studs or bolts and reinforcing bars, lapped or welded.

3) There has been great improvement in the qualities of sealant material. For example, elastomeric sealants behave largely elastic, and are flexible rather than rigid at normal service conditions.

4) In the three case studies conducted in this investigation, proper planning in desizn, production, transportation and erection of members were the major reasons for cost reduction. The total cost of precast concrete structures was less than cast-in-place structures, mainly due to the 
savings in construction time.

5) The rapid increase in the use of precast concrete members is due to repetition of similar members, increase in strength and serviceability by prestressing, rapid construction, better quality control, improvement in handing and fire resistance qualities. 


\subsection{IRAN}

From the studies of the use of precast concrete members in Iran, it may be observed that their use has increased rapidly in the last decade. This increase is also the result of most of the reasons mentioned pertaining to the increase in the United States. Also, since Iran does not have a vast supply of wood, steel and concrete are the two major construction materials, thus increasing the desireability of precast concrete construction.

It was also observed that due to the variations in climate and the occurrence of distructive earthquakes, materials with high durability, weather resistance and adequate ductility are recommended, with proper designing for stronger and more dependable structures. Precast concrete construction with proper shear design appears suitable in the areas where stronger and more frequent earthquakes occur.

This study shows that due to the production of cement, and steel reinforcement in excess of recent demands, these materials can be used economically in construction. The advantages of precast concrete members make them suitable for low-cost housing projects. Since structural members can be mass produced, the result is fewer forms required and a decrease in the total cost. 


\section{REFERENCES}

1. ACI-ASCE Committee 512, Suggested Design of Joints and Connections in Precast Structural Concrete, American Concrete Institute, August 1964.

2. ACI Committee 318 , Building Code Requirements for Reinforced Concrete (ACI 318-71), American Concrete Institute, Detroit 1971.

3. ACI Committee 318, Commentary on Building Code Requirements for Reinforced Concrete (ACI 318-71), American Concrete Institute, Detroit 1971.

4. ACI Committee 315, Manual of Standard Practice for Detailing Reinforced Concrete Structures (ACI 315-65), Amexican Concrete Institute, Detroit 1970.

5. American Concrete Institute, "Symposium on Fire Resistance of Concrete," ACI SP-5, 1961.

6. American Concrete Institute, "Symposium on Precast Concrete Yall Panels," ACI SP-11, 1966.

7. Birkelanc, Jalvard W., and Birkeland, Philip W., "Connections in Precast Concrete Constructions," ACI Journal, Narch i966.

8. Concrete Reinforcing Steel Institute, CRSI Handbook, Based Upon the 1971 ACI Building Code, 1972.

9. Engineering News-Record, "Precast Elements Form a Stylish Garage," NicGraw-Hill, Inc., December 22, 1966.

10. Ferguson, Phil M., Reinforced Concrete Fundamentals, Join Wiley and Sons, Inc., 1967.

11. International Symposium on Low-Cost Housing Problems Related to Urban Renewal and Development, "Modular Housing Systems Around the World and in the U.S.A.," Civil Engineering Department, University of MissouriRolla, October 1971.

12. LaGue, David J., P.E., "Load Distribution Tests on Precast Prestressed Hollow-Core Slab Construction," PCI Journal, December 1971. 
13. Laszlo, George, Chief Engineer, "A Jewel in Concrete," Empire Prestress, Inc., 1972.

14. Linn, T. Y., Design of Prestressed Concrete Structures, John Wiley and Sons, Inc., 1963.

15. National Loss Control Service Corporation, "High Rise Building Fire Protection Study," City of Chicago, September 1971.

16. Portland Cement Association, "Design and Control of Concrete Mixture," PCA, July 1968.

17. Prestressed Concrete Institute, PCI Design Handbook, Precast and Prestressed Concrete, 1971.

18. Prestressed Concrete Institute, "The Urban Way of Life," PCItems, Vol. 12, No. 6, June 1966.

19. Prestressed Concrete Institute Committee, "Joint Design, Details and Sealant Materials," PCI Journal, August 1973.

20. Shemie, Milo, "Bolted Connections in Large Panel System Buildings," PCI Jourmal, January 1973.

21. Stressteel Corporation, "Post-Tensioning Technique for Modular Systems Construction," Stressteel Corporation, Technical Bulletin ił 32 , October 1969.

22. The Eco of Iran, Iran Almanac, Tehran, Iran, 1972. 


\section{VITA}

Khosrow Ebadi Farshchi was born in Bandar Mashore, Iran, on October 25, 1949, the son of Ali Akbar Ebadi Farshchi and Rabiah Ebadi Farshchi. He graduated from Hadaf High School, Tehran, Iran in June 1968. He entered Southeasterm State College in Durant, Oklahoma, in January 1969 and transferred to Oregon State University in September 1970, where he received a Bachelor of Science Degree in Civil Engineering in June 1972. He entered the Graduate School in the Department of Applied Science (Structural Engineering) in september 1972.

Permanent address: 456 Eixst Andisieh, Abas Abad Ave., Tehran, Iran

This thesis was typed by Jo T. Levstone 